Nevada

Environmental

Restoration

Project

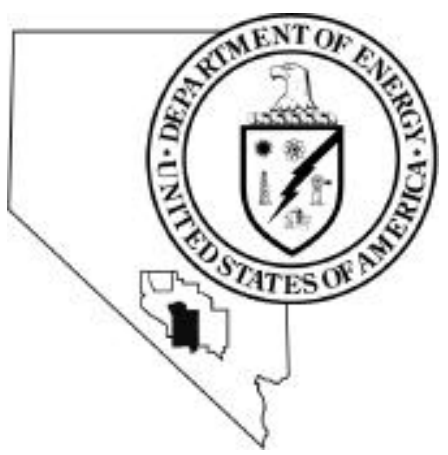

Corrective Action Decision Docum ent for Corrective Action Unit 2 40:

Area 25 Vehicle W ashdown,

$\mathrm{N}$ evada Test $\mathrm{Site}, \mathrm{N}$ evada

Controlled Copy N $0 .:$

Revision N 0.: 0

September 1999

Approved for public release; further dissemination unlimited.

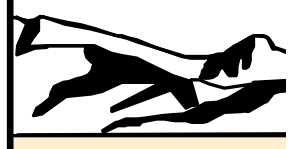

Environm ental Restoration

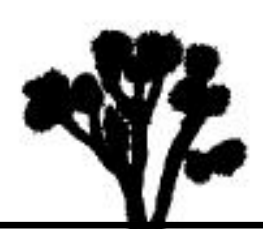

Division 
Available to the public from -
U.S. Department of Commerce
National Technical Information Service
5285 Port Royal Road
Springfield, VA 22161
(703) 487-4650

Available electronically at http://www.doe.gov/bridge. Available to

U.S. Department of Energy and its contractors in paper from -

U.S. Department of Energy

Office of Scientific and Technical Information

P.O. Box 62

Oak Ridge, TN 37831-0062

(423) 576-8401

Reference herein to any specific commercial product, process, or service by trade name, trademark, manufacturer, or otherwise, does not necessarily constitute or imply its endorsement, recommendation, or favoring by the United States Government or any agency thereof or its contractors or subcontractors. 


\title{
CORRECTIVE ACTION DECISION DOCUMENT FOR CORRECTIVE ACTION UNIT 240: AREA 25 VEHICLE WASHDOWN, NEVADA TEST SITE, NEVADA
}

\author{
DOE Nevada Operations Office \\ Las Vegas, Nevada
}

Controlled Copy No.:

Revision No.: 0

September 1999

Approved for public release; further dissemination unlimited. 


\section{CORRECTIVE ACTION DECISION DOCUMENT \\ FOR CORRECTIVE ACTION UNIT 240: \\ AREA 25 VEHICLE WASHDOWN, NEVADA TEST SITE, NEVADA}

Approved by:

Janet Appenzeller-Wing, Project Manager

Industrial Sites Project

Approved by:

Signature Approved

Date: $\quad 9 / 16 / 99$

Runore C. Wycoff, Division Director

Environmental Restoration Division 


\section{Table of Contents}

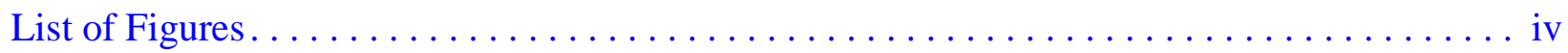

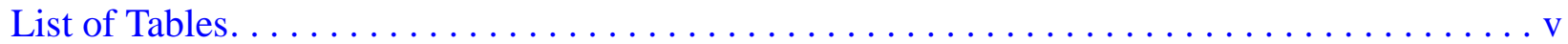

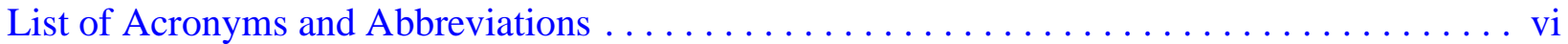

Executive Summary . . . . . . . . . . . . . . . . . . . . . . . ES-1

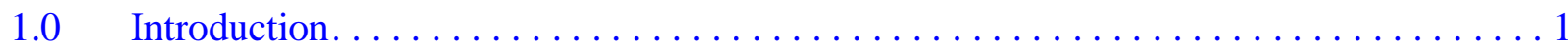

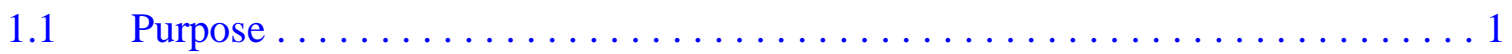

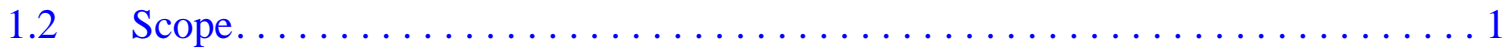

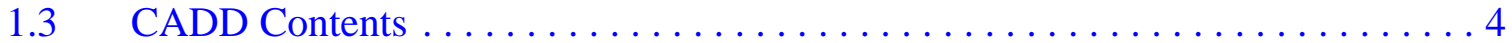

2.0 Corrective Action Investigation Summary $\ldots \ldots \ldots \ldots \ldots \ldots \ldots \ldots \ldots \ldots \ldots \ldots \ldots \ldots \ldots$

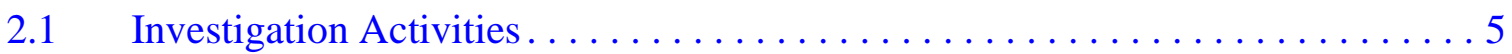

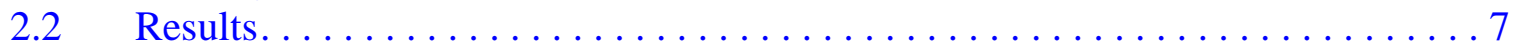

$2.3 \quad$ Need for Corrective Action. . . . . . . . . . . . . . . . . . . . . . 9

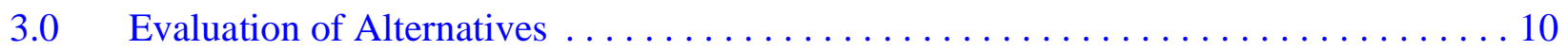

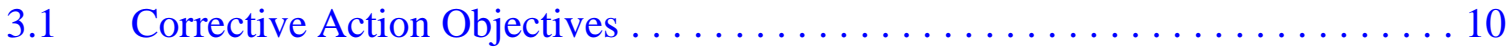

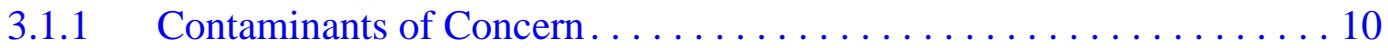

3.1.2 Potential Exposure Pathways . . . . . . . . . . . . . . . . 10

$3.2 \quad$ Screening Criteria . . . . . . . . . . . . . . . . . . . . . . 11

3.2.1 Corrective Action Standards. . . . . . . . . . . . . . . . . . 11

3.2.2 Remedy Selection Decision Factors. . . . . . . . . . . . . . . . . . . . 13

3.3 Development of Corrective Action Alternatives . . . . . . . . . . . . . 14

3.3.1 Alternative 1 - No Further Action . . . . . . . . . . . . . 16

3.3.2 Alternative 2 - Clean Closure by Excavation and Disposal . . . . . . . . 17

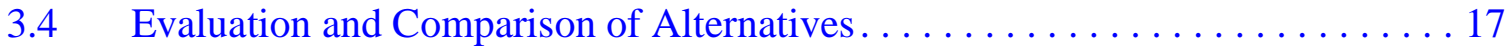

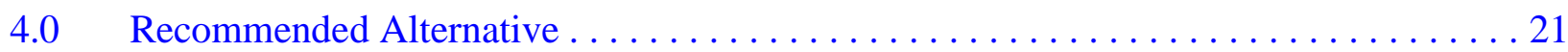

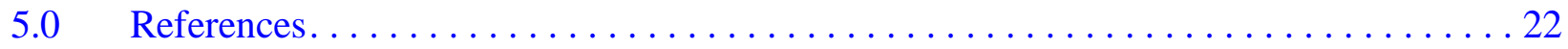

\section{Appendix A - Corrective Action Investigation Report for CAU 240:} Area 25 Vehicle Washdown, Nevada Test Site, Nevada

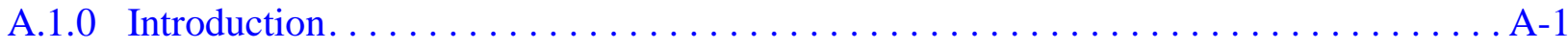

A.1.1 Project Objectives . . . . . . . . . . . . . . . .

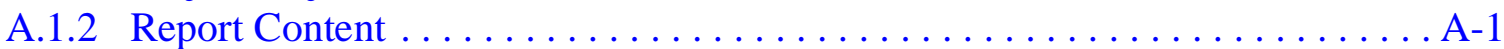

A.2.0 Field Investigation and Sampling Activities. . . . . . . . . . . . A-3

A.2.1 Site Descriptions and Conditions . . . . . . . . . . . . . A-4 


\section{Table of Contents (Continued)}

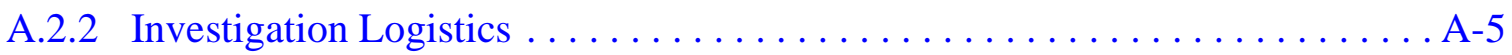

A.2.2.1 Sample Locations . . . . . . . . . . . . . . . . . . A-5

A.2.2.2 Excavation Activities ...................... A

A.2.2.3 Video Survey Activities . . . . . . . . . . . . . . . . . . . . A

A.2.2.4 Direct-Push Sampling. . . . . . . . . . . . . . . . . . . A

A.2.2.5 Field-Screening. . . . . . . . . . . . . . . . . . . . . . . A A-9

A.2.3 Sample Collection. . . . . . . . . . . . . . . . . . . . . . A-9

A.2.3.1 CAS 25-07-01, Propellant Pad . . . . . . . . . . . . . . A-10

A.2.3.2 CAS 25-07-03, RADSAFE Pad ................... A-11

A.2.3.3 CAS 25-07-02, F and J Roads Pad .................. A-11

A.2.3.4 Background Sampling . . . . . . . . . . . . . . . . A 12

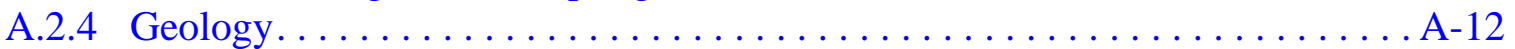

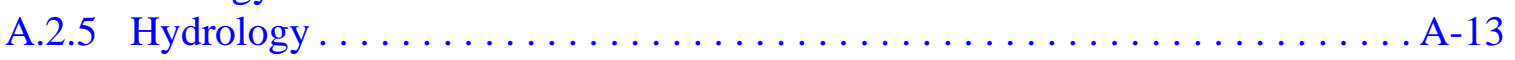

A.3.0 Investigation Results. . . . . . . . . . . . . . . . . . . . A-14

A.3.1 Total Volatile Organic Compound Analytical Results . . . . . . . . . . . . . . . A-20

A.3.2 Total Semivolatile Organic Compound Analytical Results . . . . . . . . . . . A-22

A.3.3 Total Petroleum Hydrocarbon Analytical Results . . . . . . . . . . . . . A-23

A.3.4 Total RCRA Metals Results . . . . . . . . . . . . . . . . . . . . . . . . . . A-23

A.3.5 Total Pesticides Results . . . . . . . . . . . . . . . . . . . . A-23

A.3.6 PCB Results . . . . . . . . . . . . . . . . . . . . . A-24

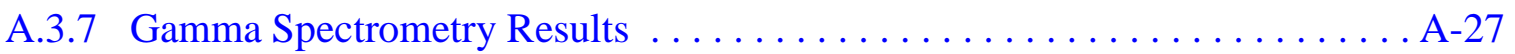

A.3.8 Isotopic Uranium, Isotopic Plutonium, and Strontium-90 Results . . . . . . . . A-27

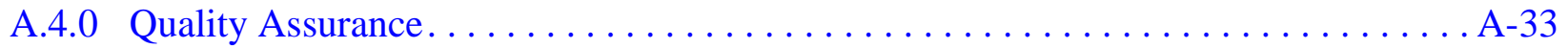

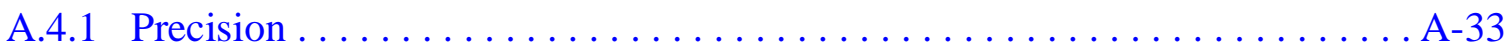

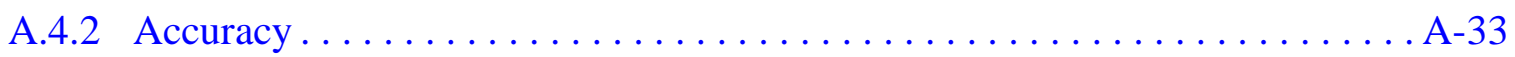

A.4.3 Representativeness . . . . . . . . . . . . . . . . . . . $\ldots \ldots$

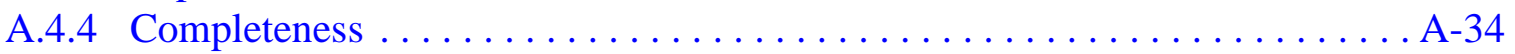

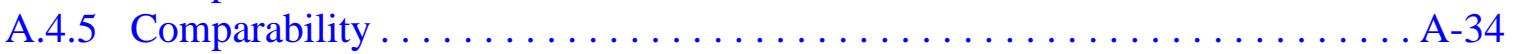

A.4.6 Tier I and Tier II Data Evaluations. . . . . . . . . . . . . . A-35

A.4.6.1 Tier I Evaluation. . . . . . . . . . . . . . . . . . . . . A A-35

A.4.6.2 Tier II Evaluation $\ldots \ldots \ldots \ldots \ldots \ldots \ldots \ldots \ldots \ldots \ldots \ldots \ldots \ldots \ldots \ldots \ldots$

A.4.6.3 Tier III . . . . . . . . . . . . . . . . . . . . . . . . . . . . . . . . . $\ldots$

A.4.7 Quality Control Samples. . . . . . . . . . . . . . . . . . . A-38

A.4.7.1 Field Quality Control Samples . . . . . . . . . . . . . . . A-38

A.4.7.2 Laboratory Quality Control Samples . . . . . . . . . . . . . . . . . A-39

A.4.8 Field Nonconformances . . . . . . . . . . . . . . . . . . . . . . . A-41

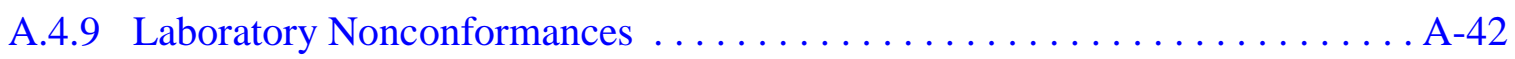




\section{Table of Contents (Continued)}

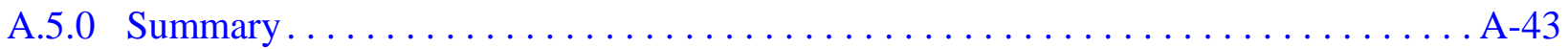

A.6.0 References....................................... A-44

Appendix B - Cost Estimates

Appendix C - Response to NDEP Comments 


\section{List of Figures}

Number

1-1 Nevada Test Site . . . . . . . . . . . . . . . . . . . . . . . . . 2

1-2 CAU 240, Area 25 Vehicle Washdown, Nevada Test Site . . . . . . . . . . . . . 3

2-1 Contamination Locations at CAS 25-07-02, Vehicle Washdown Area (F and J Roads Pad), Area 25, Nevada Test Site . . . . . . . . . . . . . . . 8

A.2-1 Sample Locations at CAS 25-07-01, Vehicle Washdown Area (Propellant Pad), Area 25, Nevada Test Site . . . . . . . . . . . . . . . . A-6

A.2-2 Sample Locations at CAS 25-07-03, Vehicle Washdown Station (RADSAFE Pad), Area 25, Nevada Test Site .

A.2-3 Sample Locations at CAS 25-07-02, Vehicle Washdown Area (F and J Roads Pad), Area 25, Nevada Test Site. . . . . . . . . . . . . . . . A-8 


\section{List of Tables}

Number

3-1 Detailed Evaluation of Alternatives. ........................... 18

3-2 Comparative Evaluation of Alternatives ...................... 20

A.3-1 Samples Collected During the CAU 240 Area 25 Vehicle Washdown Corrective Action Investigation. . . . . . . . . . . . . . . . . . A-14

A.3-2 Laboratory Analytical Methods Used for Samples Collected at the CAU 240, Area 25 Vehicle Washdown, Nevada Test Site . .

A.3-3 Soil Sample Results for Total Volatile Organic Compounds Detected Above Minimum Reporting Limits, Area 25 Vehicle Washdown, Nevada Test Site . .

A.3-4 Soil Sample Results for Total Petroleum Hydrocarbons Detected Above Minimum Reporting Limits, Area 25 Vehicle Washdown, Nevada Test Site ...

A.3-5 Summary of Total RCRA Metals Results Detected Above Minimum Reporting Limits, Area 25 Vehicle Washdown, Nevada Test Site..

A.3-6 Summary of Total Pesticides Results Detected Above Minimum Reporting Limits, Area 25 Vehicle Washdown, Nevada Test Site.

A.3-7 Soil Sample Results for Gamma Spectrometry Above Contract Required Detection Limit, Area 25 Vehicle Washdown, Nevada Test Site

A.3-8 Soil Sample Results for Isotopic Uranium and Strontium-90 Detected Above Contract Required Detection Limit, Area 25 Vehicle Washdown, Nevada Test Site 


\section{List of Acronyms and Abbreviations}

bgs Below ground surface

CADD Corrective Action Decision Document

CAIP Corrective Action Investigation Plan

CAS Corrective Action Site

CAU Corrective Action Unit

CFR Code of Federal Regulations

CLP Contract Laboratory Program

COC Contaminant(s) of concern

COPC Contaminant(s) of potential concern

CPSA Central Propellant Support Area

DDD Dichlorodiphenyldichloroethane

DDE Dichlorodiphenyldichloroethylene

DDT Dichlorodiphenyltrichloroethylene

DOE/NV U.S. Department of Energy, Nevada Operations Office

DQO Data Quality Objective(s)

EPA U.S. Environmental Protection Agency

FFACO Federal Facility Agreement and Consent Order

$\mathrm{ft} \quad$ Foot (feet)

ICP Inductively coupled plasma

in. $\operatorname{Inch}(\mathrm{es})$

LCS Laboratory control sample(s)

MEK Methylethyl ketone (2-butanone)

mi Mile(s)

$\mathrm{mg} / \mathrm{kg} \quad$ Milligram(s) per kilogram

MS/MSD Matrix spike and matrix spike duplicate

NAC Nevada Administrative Code

NDEP Nevada Division of Environmental Protection 


\section{List of Acronyms and Abbreviations (Continued)}

NIST National Institute for Standards and Technology

NRS Nevada Revised Statutes

NRDS Nuclear Rocket Development Station

NTS Nevada Test Site

PAL Preliminary action level(s)

PCB Polychlorinated biphenyl(s)

$\mathrm{pCi} / \mathrm{g} \quad$ Picocurie(s) per gram

ppm Part(s) per million

PRG Preliminary Remediation Goals

PVC Polyvinyl chloride

QA Quality assurance

QAPP Quality Assurance Project Plan

QC Quality control

RCRA Resource Conservation and Recovery Act

RPD Relative percent difference

SDG Sample delivery group

SVOC Semivolatile organic compound(s)

TPH Total petroleum hydrocarbons

VOC Volatile organic compound(s)

$\mathrm{yd}^{3} \quad$ Cubic yard(s)

$\mu \mathrm{g} / \mathrm{kg} \quad$ Microgram(s) per kilogram

$\% \mathrm{R} \quad$ Percent recovery 


\section{Executive Summary}

This Corrective Action Decision Document has been prepared for Corrective Action Unit 240, Area 25 Vehicle Washdown. The corrective action investigation was conducted in accordance with the Corrective Action Investigation Plan for Corrective Action Unit 240: Area 25 Vehicle Washdown, Nevada Test Site, Nevada (DOE/NV, 1999) as developed under the Federal Facility Agreement and Consent Order (FFACO, 1996). Corrective Action Unit 240 is located in Area 25 at the Nevada Test Site, Nevada, and is comprised of the following Corrective Action Sites:

- 25-07-01; Vehicle Washdown Area (Propellant Pad)

- 25-07-02; Vehicle Washdown Area (F and J Roads Pad)

- 25-07-03; Vehicle Washdown Station (RADSAFE Pad)

The purpose of this Corrective Action Decision Document is to identify and provide a rationale for the selection of a recommended corrective action alternative for each Corrective Action Site.

The scope of this Corrective Action Decision Document consists of the following tasks:

- Develop corrective action objectives.

- Identify corrective action alternative screening criteria.

- Develop corrective action alternatives.

- Perform detailed and comparative evaluations of the corrective action alternatives in relation to the corrective action objectives and screening criteria.

- Recommend and justify a preferred corrective action alternative for each Corrective Action Site.

A corrective action investigation was performed in March 1999 as set forth in the Corrective Action Investigation Plan for Corrective Action Unit 240: Area 25 Vehicle Washdown, Nevada Test Site, Nevada (DOE/NV, 1999). Analytes detected during the corrective action investigation were evaluated against preliminary action levels to determine contaminants of concern for Corrective Action Unit 240. There were no contaminants of concern identified at Corrective Action Site 25-07-01, Propellant Pad, or Corrective Action Site 25-07-03, RADSAFE Pad, so there is no need for corrective action at these Corrective Action Sites. 
Diesel-range organics and radionuclide concentrations in soil samples taken from the $\mathrm{F}$ and $\mathrm{J}$ Roads Pad exceeded preliminary action levels. Based on the identification of contaminants of concern above preliminary action levels at this site, potential corrective action alternatives are identified and evaluated in this Corrective Action Decision Document to ensure worker, public, and environmental protection against potential exposure to contaminants of concern in accordance with Nevada Administrative Code 445A (NAC, 1997b).

Based on the potential exposure pathways, the following corrective action objectives have been identified for the F and J Roads Pad:

- Prevent or mitigate exposure to surface and near-surface soil containing contaminants of concern at concentrations exceeding preliminary action levels as defined in the Corrective Action Investigation Plan (DOE/NV, 1999).

- Prevent spread of contaminants of concern beyond the Corrective Action Site.

Based on the review of existing data, future use, and current operations in Area 25, the following alternatives were developed for consideration at the F and J Roads Pad:

- Alternative 1 - No Further Action

- Alternative 2 - Clean Closure by Excavation and Disposal

The corrective action alternatives were evaluated based on four general corrective action standards and five remedy selection decision factors. Based on the results of this evaluation, the preferred alternative for the F and J Roads Pad is Alternative 2, Clean Closure by Excavation and Disposal.

The preferred corrective action alternative was evaluated on technical merit, focusing on performance, reliability, feasibility, and safety. The alternative was judged to meet all requirements for the technical components evaluated. The alternative meets all applicable state and federal regulations for closure of the site and will eliminate potential future exposure pathways to the contaminated soils at the F and J Roads Pad.

During corrective action implementation, this alternative may potentially present low risks to site workers who come in contact with the contaminated soil. Therefore, procedures will be developed and implemented to ensure worker health and safety. 
This Corrective Action Decision Document (CADD) has been prepared for Corrective Action Unit (CAU) 240, Area 25 Vehicle Washdown, in accordance with the Federal Facility Agreement and Consent Order (FFACO) of 1996 that was agreed to by the U.S. Department of Energy, Nevada Operations Office (DOE/NV); the Nevada Division of Environmental Protection (NDEP); and the U.S. Department of Defense (FFACO, 1996). The CADD provides or references the specific information necessary to recommend corrective actions for the Corrective Action Sites (CASs) within CAU 240, which include the following:

- 25-07-01; Vehicle Washdown Area (Propellant Pad)

- 25-07-02; Vehicle Washdown Area (F and J Roads Pad)

- 25-07-03; Vehicle Washdown Station (RADSAFE Pad)

Corrective Action Unit 240 is located in Area 25 at the Nevada Test Site (NTS) in Nevada. The NTS is approximately 65 miles (mi) northwest of Las Vegas, Nevada (Figure 1-1 and Figure 1-2).

\subsection{Purpose}

This CADD identifies potential corrective action alternatives and provides a rationale for the selection of a recommended corrective action alternative for each CAS within the CAU. The need for evaluation of corrective action alternatives is based on process knowledge and the results of investigative activities conducted in accordance with the Corrective Action Investigation Plan for Corrective Action Unit 240: Area 25 Vehicle Washdown, Nevada Test Site, Nye County, Nevada (CAIP) (DOE/NV, 1999).

\subsection{Scope}

The scope of this CADD consists of the following:

- Develop corrective action objectives.

- Identify corrective action alternative screening criteria.

- Develop corrective action alternatives. 


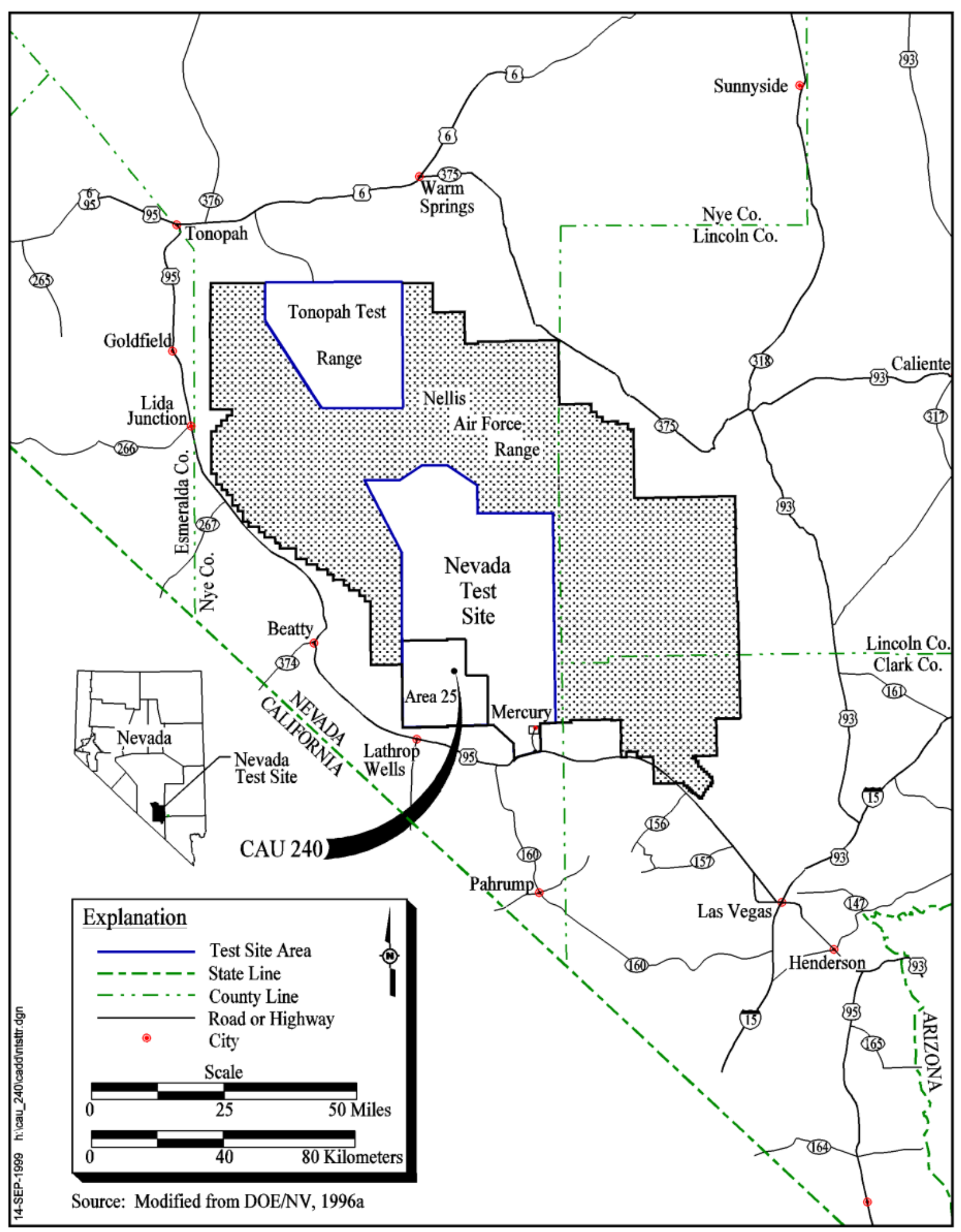

Figure 1-1 


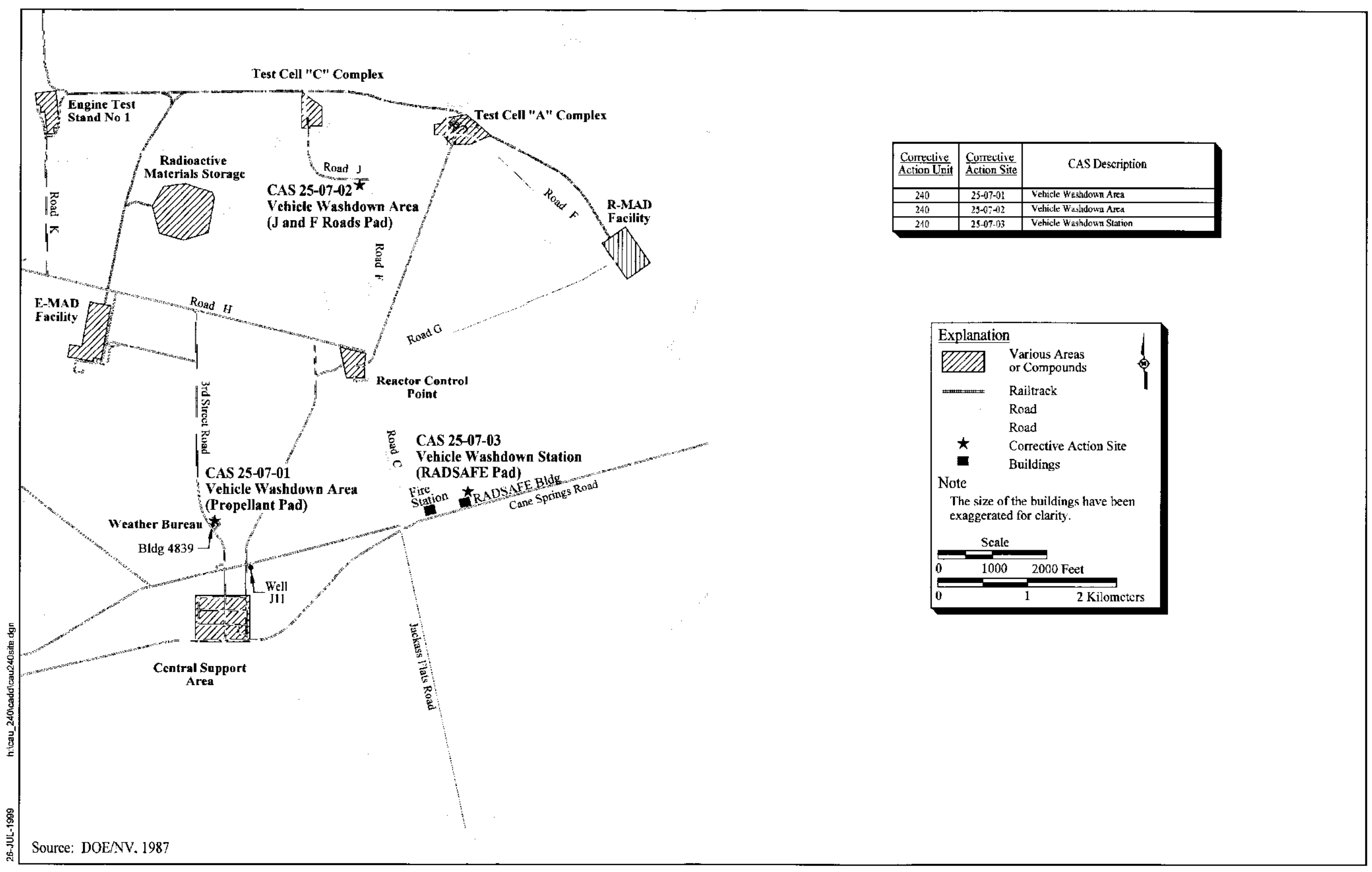


- Perform detailed and comparative evaluations of corrective action alternatives in relation to corrective action objectives and screening criteria.

- Recommend and justify a preferred corrective action alternative for each CAS within the CAU.

\section{$1.3 \quad C A D D$ Contents}

This CADD is divided into the following sections:

Section 1.0 - Introduction: summarizes the purpose, scope, and contents of this CADD.

Section 2.0 - Corrective Action Investigation Summary: summarizes the investigation field activities, the results of the investigation, and the need for corrective action.

Section 3.0 - Evaluation of Alternatives: documents steps taken to determine a preferred corrective action alternative.

Section 4.0 - Recommended Alternative: presents the preferred corrective action alternative and the rationale for its selection based on the corrective action objectives and alternative screening criteria.

Section 5.0 - References: provides a list of all referenced documents.

Appendix A: Corrective Action Investigation Report for CAU 240: Area 25 Vehicle Washdown, Nevada Test Site, Nevada.

Appendix B: Cost estimates.

All work was performed in accordance with the following documents:

- $\quad$ CAIP (DOE/NV, 1999)

- Industrial Sites Quality Assurance Project Plan (QAPP) (DOE/NV, 1996b)

- FFACO (FFACO, 1996)

- Project Management Plan (DOE/NV, 1994) 


\subsection{Corrective Action Investigation Summary}

The following sections describe and summarize the results of the investigation activities conducted at CAU 240. For detailed investigation results, please refer to Appendix A.

\section{$2.1 \quad$ Investigation Activities}

From March 1 through March 17, 1999, corrective action investigation activities were performed as set forth in the CAIP (DOE/NV, 1999). The purpose of the investigation is described as follows:

- Identify the presence and concentrations of contaminants of potential concern (COPCs) at each CAS.

- Determine the vertical and lateral extent of COPCs.

- Provide sufficient information and data from which corrective action alternatives may be developed and evaluated in this CADD for each CAS.

Investigation activities were conducted at each CAS. These activities are summarized below:

CAS 25-07-01 (Propellant Pad)

- Collected a total of four background surface and near-surface samples from two undisturbed locations. These samples were analyzed for total Resource Conservation and Recovery Act (RCRA) metals; strontium-90; radioactive isotopes by gamma spectrometry; and isotopic uranium and plutonium.

- Field screened soil samples for volatile organic compounds (VOCs) and alpha/beta and gamma emitters.

- Collected a total of 16 surface and near-surface soil samples from 8 locations using a directpush method (Geoprobe ${ }^{\circledR}$ ). These samples were collected from 0 to 1 feet (ft) and 3 to $5 \mathrm{ft}$ below ground surface (bgs). Fifteen of the samples were submitted for laboratory analyses.

- All nonbackground soil samples were analyzed for total VOCs; total semivolatile organic compounds (SVOCs); total polychlorinated biphenyls (PCBs); total pesticides; and radioactive isotopes by gamma spectrometry. Gamma spectrometry results did not exceed the preliminary action levels (PALs); therefore, analyses for isotopic uranium and plutonium were not performed. 
CAS 25-07-02 (F and J Roads Pad)

- Conducted a video mole survey of the sewer pipe located in the gravel sump.

- Collected a total of four background surface and near-surface samples from two undisturbed locations. These samples were analyzed for total RCRA metals; strontium-90; radioactive isotopes by gamma spectrometry; and isotopic uranium and plutonium.

- Field-screened soil samples for VOCs and alpha/beta and gamma emitters.

- Collected a total of 26 surface, near-surface, and subsurface soil samples from 12 locations using a direct-push method (Geoprobe $\left.{ }^{\circledR}\right)$. These samples were collected from 0 to $1 \mathrm{ft}$ and 3 to $5 \mathrm{ft}$ bgs. Samples were also collected at 5 to $7 \mathrm{ft}$ and 7 to $9 \mathrm{ft}$ bgs using a Geoprobe ${ }^{\circledR}$ at two locations where field-screening results exceeded field-screening levels. Twenty-nine samples were submitted for laboratory analyses.

- Collected a total of six soil samples from three locations at the F and J Roads Pad using a backhoe. These samples were collected from 0 to $1 \mathrm{ft}$ and 1 to $2 \mathrm{ft}$ below the gravel/soil interface in the sump. The samples were submitted for laboratory analyses.

- All nonbackground soil samples were analyzed for total VOCs; total SVOCs; total RCRA metals; total PCBs; total pesticides; total petroleum hydrocarbons (TPH) as diesel/waste oil; strontium-90; radioactive isotopes by gamma spectrometry; and isotopic uranium and plutonium if gamma spectrometry results exceeded PALs.

\section{CAS 25-07-03 (RADSAFE Pad)}

- Conducted a video mole survey of the asbestos-cement pipe located at the northwest corner of the pad and the pipe from the metal vault at the northeast corner of the concrete pad.

- Collected a total of four background surface and near-surface soil samples from two undisturbed locations. These samples were analyzed for total RCRA metals; strontium-90; radioactive isotopes by gamma spectrometry; and isotopic uranium and plutonium.

- Field screened soil samples for VOCs and alpha/beta and gamma emitters.

- Collected a total of 19 surface and near-surface soil samples from 9 locations at the RADSAFE Pad using a direct-push method $\left(\right.$ Geoprobe $\left.^{\circledR}\right)$. These samples were collected from 0 to $1 \mathrm{ft}$ and 3 to $5 \mathrm{ft}$ bgs. The samples were submitted for laboratory analyses.

- Nonbackground soil samples were analyzed for some or all of the following: total VOCs; total SVOCs; total RCRA metals; total PCBs; total pesticides; TPH as diesel/waste oil; and 
radioactive isotopes by gamma spectrometry. Gamma spectrometry results did not exceed the PALs; therefore, analyses for isotopic uranium and plutonium were not performed.

\subsection{Results}

The corrective action investigation analytical results indicated the following:

- All total VOCs, total SVOCs, PCBs, and pesticides results were below the PALs outlined in the CAIP (DOE/NV, 1999) at all CASs.

- Total petroleum hydrocarbon concentrations exceeded the NDEP action level of 100 milligrams per kilogram $(\mathrm{mg} / \mathrm{kg}$ ) for diesel around the perimeter of the concrete decontamination pad at F and J Roads Pad. The TPH action level was not exceeded at the other two CASs.

- Reported levels for all total RCRA metal samples (arsenic, barium, cadmium, chromium, lead, mercury, selenium, and silver) were below the PALs established in the CAIP (DOE/NV, 1999) except for arsenic. Arsenic was detected above the PAL of $3.0 \mathrm{mg} / \mathrm{kg}$ in most of the samples analyzed. The arsenic concentrations for the samples analyzed ranged from 1.9 to $10.2 \mathrm{mg} / \mathrm{kg}$. Although these concentrations exceed the PAL for arsenic, these concentrations are not unusual for this portion of the state of Nevada; therefore, these concentrations do not imply contamination and arsenic is not a contaminant of concern (COC).

- Radiological results for the Propellant Pad and the RADSAFE Pad are considered not to be statistically different from their respective established background levels and; therefore, are within the PALs and radionuclides are not considered COCs.

- Radiological results from the F and J Roads Pad indicated that two samples had concentrations above established background levels and; therefore, are above PALs. Sample VWDFJ011 had a strontium-90 concentration of $6.9 \pm 1.3$ picocuries per gram ( $\mathrm{pCi} / \mathrm{g})$. Sample VWDFJ013 had cesium-137 and strontium-90 concentrations of $14.7 \pm 1.6 \mathrm{pCi} / \mathrm{g}$ and $12.5 \pm 2.3 \mathrm{pCi} / \mathrm{g}$, respectively. All other results, including the isotopic uranium and plutonium results for sample VWDFJ013, are considered not to be statistically different from their respective established background levels and; therefore, are below PALs.

Details of the methods used and results found during the investigation are presented in Appendix A. Based on these results, the concentrations and extent of COCs at CAU 240 (see Figure 2-1) have been adequately identified to develop and evaluate corrective action alternatives. 


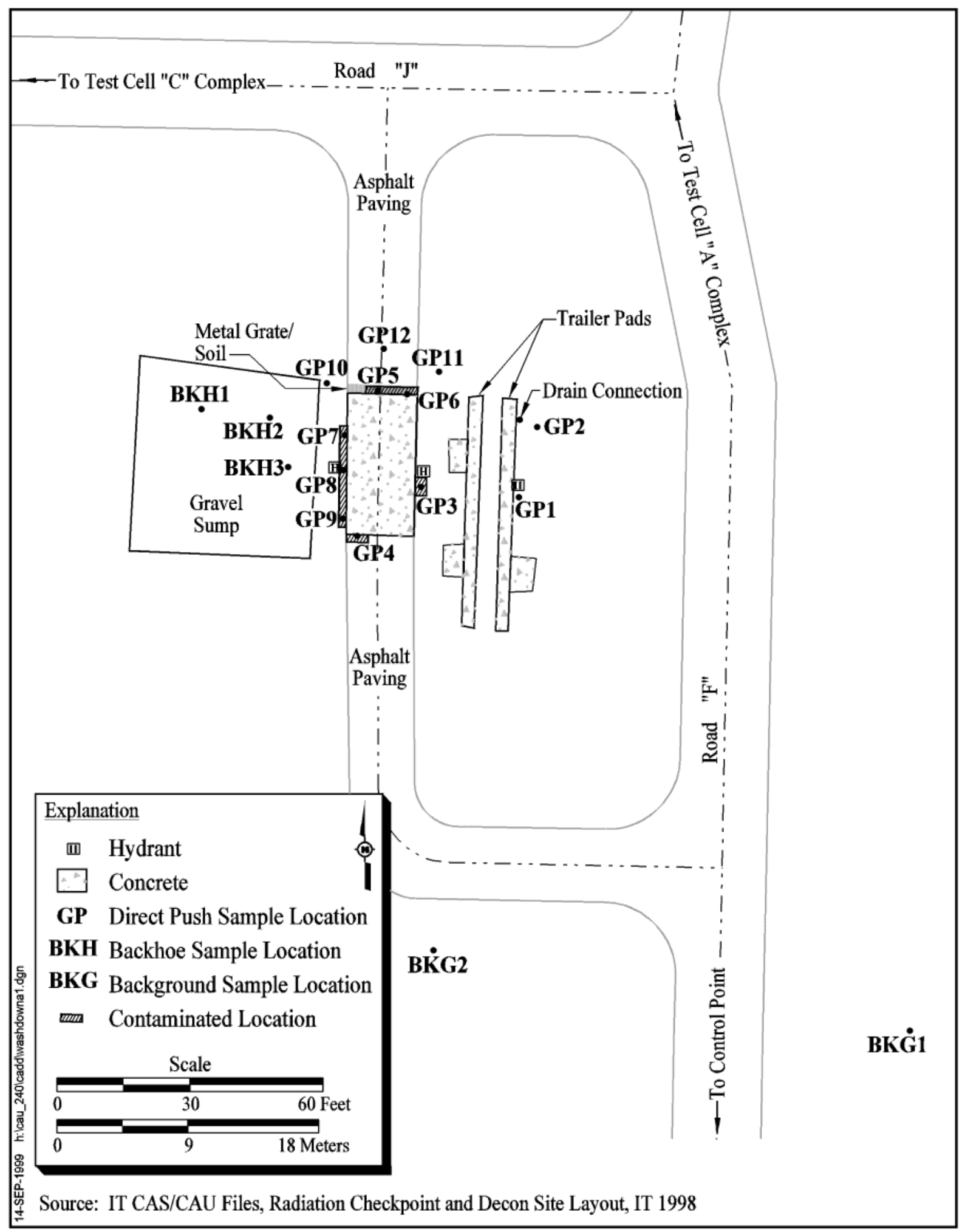

Figure 2-1

Contamination Locations at CAS 25-07-02, Vehicle Washdown Area

(F and J Roads Pad), Area 25, Nevada Test Site 


\subsection{Need for Corrective Action}

Analytes detected during the corrective action investigation were evaluated against PALs to determine COCs for CAU 240. There were no COCs identified at CAS 25-07-01, Propellant Pad, or CAS 25-07-03, RADSAFE Pad, so there is no need for corrective action at these CASs.

The TPH-diesel and radiological results from the F and J Roads Pad exceeded PALs. Based on the identification of COCs above PALs at this CAS, potential corrective action alternatives are identified and evaluated in this CADD to ensure worker, public, and environmental protection against potential exposure to COCs in accordance with Nevada Administrative Code (NAC) 445A (NAC, 1997b).

The estimated volume of impacted soil is 19 cubic yards $\left(\mathrm{yd}^{3}\right)$ at the F and J Roads Pad. The contamination extends to a maximum depth of $6 \mathrm{ft}$ vertically and around the perimeter of the concrete pad (Figure 2-1).

There are no site-specific characteristics that will constrain remediation at the F and J Roads Pad. 


\subsection{Evaluation of Alternatives}

The purpose of this section is to present the corrective action objectives for the F and J Roads Pad, describe the general standards and decision factors used to screen the corrective action alternatives, and develop and evaluate a set of corrective action alternatives that could be used to meet the corrective action objectives.

\subsection{Corrective Action Objectives}

The corrective action objectives are media-specific goals for protecting human health and the environment. Based on the potential exposure pathways (see Section 3.1.2), the following corrective action objectives have been identified for the F and J Roads Pad:

- Prevent or mitigate exposure to surface and near-surface soil containing COCs at concentrations exceeding PALs as defined in the CAIP (DOE/NV, 1999).

- Prevent spread of COCs beyond the CAS.

\subsubsection{Contaminants of Concern}

Contaminants of potential concern were determined in the Data Quality Objective (DQO) process as listed in the CAIP (DOE/NV, 1999). Analytical results obtained from the corrective action investigation were evaluated to determine if COPCs were detected above PALs, and would therefore be COCs for CAU 240 that must be addressed by corrective action. Based on the results of this evaluation, TPH-diesel and radionuclides were identified as COCs for the F and J Roads Pad.

\subsubsection{Potential Exposure Pathways}

As identified in the CAIP, the future use for the F and J Roads Pad is assumed to include light industrial, industrial, educational tours, research, and support sites. As part of the CAIP (DOE/NV, 1999), a conceptual model for CAU 240 was developed which identified the potential exposure mechanism as disturbance of contaminated soil by site workers. This implies a potential exposure pathway through ingestion of, inhalation of, and dermal contact with contaminated soil under industrial scenarios. Site workers could potentially be exposed to contaminated soil during general maintenance or construction and maintenance of underground utilities. The well (J-11) 
nearest the F and J Roads Pad is located approximately 14,900 ft southwest of the F and J Roads Pad. The depth to groundwater at this well is approximately 1,040 ft bgs (USGS, 1993). These factors, along with others presented in Section 3.3, support the determination that contaminant migration to groundwater is not considered to be an exposure pathway.

\subsection{Screening Criteria}

The screening criteria used to evaluate and select the preferred corrective action alternatives are identified in the U.S. Environmental Protection Agency (EPA) Guidance on RCRA Corrective Action Decision Documents (EPA, 1991) and the Final RCRA Corrective Action Plan (EPA, 1994).

Corrective action alternatives will be evaluated based on four general corrective action standards and five remedy selection decision factors. All corrective action alternatives must meet the general standards to be selected for evaluation using the remedy selection decision factors.

The general corrective action standards are as follows:

- Protection of human health and the environment

- Compliance with media cleanup standards

- Control the source(s) of the release

- Compliance with applicable federal, state, and local standards for waste management

The remedy selection decision factors are as follows:

- Short-term reliability and effectiveness

- Reduction of toxicity, mobility, and/or volume

- Long-term reliability and effectiveness

- Feasibility

- Cost

\subsubsection{Corrective Action Standards}

The following text describes the corrective action standards used to evaluate the corrective action alternatives.

\section{Protection of Human Health and the Environment}

Protection of human health and the environment is a general mandate of the RCRA statute (EPA, 1994). This mandate requires that the corrective action include any protective measures that 
are necessary. These measures may or may not be directly related to media cleanup, source control, or management of wastes. The corrective action alternatives are evaluated for the ability to meet corrective action objectives as defined in Section 3.1.

\section{Compliance with Media Cleanup Standards}

Each corrective action alternative must have the ability to meet the proposed media cleanup standards as set forth in applicable state and federal regulations, and as specified in the CAIP (DOE/NV, 1999). For this CAU, the EPA's Region 9 Preliminary Remediation Goals (PRGs), which are derived from the Integrated Risk Information System, are the basis for establishing the PALs for chemical contaminants under NAC 445A.2272 (NAC, 1997b). The PAL for petroleum substances in soil is $100 \mathrm{mg} / \mathrm{kg}$ in accordance with NAC 445A.2272 (NAC, 1997b). The PALs for radiological contaminants are based on background concentrations. Laboratory results above PALs indicate the presence of COPCs at levels that may require corrective action.

\section{Control the Source(s) of the Release}

An objective of a corrective action remedy is to stop further environmental degradation by controlling or eliminating additional releases that may pose a threat to human health and the environment. Unless source control measures are taken, efforts to clean up releases may be ineffective or, at best, will essentially involve a perpetual cleanup. Therefore, each corrective action alternative must use an effective source control program to ensure the long-term effectiveness and protectiveness of the corrective action.

\section{Comply with Applicable Federal, State, and Local Standards for Waste Management}

During implementation of any corrective action alternative, all waste management activities must be conducted in accordance with applicable state and federal regulations (e.g., Nevada Revised Statutes [NRS] 459.400 - 459.600 "Disposal of Hazardous Waste” [NRS, 1995]; 40 Code of Federal Regulations [CFR] 260 - 282 “RCRA Regulations" [CFR, 1998]; NAC 444, "Sanitation" [NAC, 1997a]; and NAC 459.9974, "Disposal and Evaluation of Contaminated Soil” [NAC, 1997c]). The requirements for management of the waste, if any, derived from the corrective action will be determined based on applicable state and federal regulations, field observations, process knowledge, characterization data, and data collected and analyzed during corrective action implementation. Administrative controls (e.g., decontamination procedures and corrective action strategies) will 
minimize waste generated during site corrective action activities. Decontamination activities will be performed in accordance with approved procedures and will be designated according to the COCs present at the site.

\subsubsection{Remedy Selection Decision Factors}

The following text describes the remedy selection decision factors used to evaluate the corrective action alternatives.

\section{Short-Term Reliability and Effectiveness}

Each corrective action alternative must be evaluated with respect to its effects on human health and the environment during implementation of the corrective action. The following factors will be addressed for each alternative:

- Protection of the community from potential risks associated with implementation such as fugitive dusts, transportation of hazardous materials, and explosion

- Protection of workers during implementation

- Environmental impacts that may result from implementation

- The amount of time until the corrective action objectives are achieved

\section{Reduction of Toxicity, Mobility, and/or Volume}

Each corrective action alternative must be evaluated for its ability to reduce the toxicity, mobility, and/or volume of the contaminated media. Reduction in toxicity, mobility, and/or volume refers to changes in one or more characteristics of the contaminated media by the use of corrective measures that decrease the inherent threats associated with that media.

\section{Long-Term Reliability and Effectiveness}

Each corrective action alternative must be evaluated in terms of risk remaining at the CAU after the corrective action alternative has been implemented. The primary focus of this evaluation is on the extent and effectiveness of the controls that may be required to manage the risk posed by treatment residuals and/or untreated wastes. 


\section{Feasibility}

The feasibility criterion addresses the technical and administrative feasibility of implementing a corrective action alternative and the availability of services and materials needed during implementation. Each corrective action alternative must be evaluated for the following criteria:

- Construction and Operation. Refers to the feasibility of implementing a corrective action alternative given the existing set of waste and site-specific conditions.

- Administrative Feasibility. Refers to the administrative activities needed to implement the corrective action alternative (e.g., permits, public acceptance, rights of way, off-site approval).

- Availability of Services and Materials. Refers to the availability of adequate off-site and on-site treatment, storage capacity, disposal services, necessary technical services and materials, and prospective technologies for each corrective action alternative.

\section{Cost}

Costs for each alternative are estimated for comparison purposes only. The cost estimate for each corrective action alternative includes both capital and operation and maintenance costs, as applicable. The following is a brief description of each component:

- Capital Costs: These costs include both direct and indirect costs. Direct costs may consist of materials, labor, mobilization, demobilization, site preparation, construction materials, equipment purchase and rental, sampling and analysis, waste disposal, and health and safety measures. Indirect costs include such items as engineering design, permits and/or fees, start-up costs, and any contingency allowances.

- Operation and Maintenance: These costs include labor, training, sampling and analysis, maintenance materials, utilities, and health and safety measures.

Cost summaries for this CADD are provided in Appendix B.

\subsection{Development of Corrective Action Alternatives}

This section identifies and briefly describes the viable corrective action technologies and the corrective action alternatives considered for the affected media. Based on the review of existing data, 
future use, and current operations at the NTS, the following alternatives have been developed for consideration at the F and J Roads Pad:

- Alternative 1 - No Further Action

- Alternative 2 - Clean Closure by Excavation and Disposal

Other technologies, such as administrative controls (closure in place) and partial excavation, were considered. Administrative controls were not considered to be protective because the COCs are located at the surface. The small volume of contaminated material and the surface location resulted in these alternatives not receiving further consideration in this CADD.

The following evaluation of NAC 445A.227 (2) (a-k) (NAC, 1997b) supports the protection of groundwater from COCs at the F and J Roads Pad:

a. Depth to groundwater at the nearest well (J-11) is approximately 1,040 ft bgs (USGS, 1993). This well is located 14,900 ft southwest of the F and J Roads Pad. Groundwater flow is generally to the southwest and may discharge at Ash Meadows (SNPO, 1970). Field screening and analytical data indicate that COCs are confined primarily from 0 to $5 \mathrm{ft}$ bgs. This indicates minimal vertical migration has occurred in the past and, with the removal of man-made driving forces, vertical migration will be negligible in the future.

b. The distance to the nearest active water-supply well, Well J-12, is approximately $5.5 \mathrm{mi}$ northwest of the F and J Roads Pad (DOE/NV, 1996a). Well J-12 is primarily used to provide potable water for Area 25. The groundwater flow direction is generally to the southwest (Laczniak et al., 1996).

c. Soil at the F and J Roads Pad is silty-to-sandy gravels. No geotechnical data were collected because COCs were assumed to occur near the ground surface. Field screening and analytical data indicate that COCs are confined primarily from 0 to $5 \mathrm{ft}$ bgs.

d. Average annual precipitation for valleys in the South-Central Great Basin ranges from 3 to 6 inches [in.] (Winograd and Thordarson, 1975). Annual evaporation is roughly 5 to 25 times the annual precipitation (Winograd and Thordarson, 1975). The high evaporation and low precipitation rates create a negative water balance for the area; therefore, no driving force associated with precipitation is available to mobilize COCs vertically.

e. The types of regulated substances released are diesel-range petroleum hydrocarbons and limited radionuclides. Downward migration of COCs is slowed by the following parameters:

- Volume of release - small volumes of COCs were released over a long period of time rather than a large volume over a short duration. 
- Soil saturation - the soil tends to be very dry, especially near the surface where the COCs are concentrated.

- Soil particle adsorption/desorption - the petroleum hydrocarbons and radionuclides tend to adsorb to the soil particles with little desorption as suggested by the limited vertical migration of COCs.

f. The lateral extent of contamination is defined by the area immediately surrounding the concrete decontamination pad. The vertical extent of contamination is primarily confined to $5 \mathrm{ft} b g \mathrm{~s}$ based on field screening and analytical data.

g. Presently, the F and J Roads Pad is located on a government-controlled facility. The NTS is a restricted area that is guarded on a 24-hour, 365-day-per-year basis; unauthorized personnel are not admitted to the facility. Future use of the F and J Roads Pad is assumed to include light industrial, industrial, educational tours, research, and support sites.

h. Preferred routes of vertical migration are nonexistent since the sources have been eliminated and driving forces are not viable. Currently, the area is controlled by fence and rope to prevent activities from further contributing to the lateral movement of the COCs; however, surface drainage may mobilize the contaminated surface soil down gradient. Precipitation events are ephemeral and highly variable in the arid environment. Wind could also mobilize the contaminants located at the surface.

i. Facility operations at the F and J Roads Pad are presently terminated (i.e., decontamination activities were last conducted in the 1970s).

j. The potential for a hazard related to fire, vapor, or explosion is nonexistent for the COCs at the F and J Roads Pad.

k. No other site-specific factors are known at this time.

Based on this evaluation, impacts to groundwater are not expected. Therefore, groundwater monitoring is not proposed for this site and is not considered an element of the alternatives.

\subsubsection{Alternative 1 - No Further Action}

Under the No Further Action Alternative, no corrective action activities will be implemented. This alternative is a baseline case with which to compare and assess the other corrective action alternative's ability to meet the corrective action standards. This alternative does not meet the corrective action objectives for the F and J Roads Pad because no actions are taken to prevent 
exposure to the COCs or to prevent continued spread of contamination. This alternative will not be compared to the other alternatives using the selection decision factors for these sites.

\subsubsection{Alternative 2 - Clean Closure by Excavation and Disposal}

Alternative 2 consists of excavating and disposing of the concrete decontamination pad and the soil with TPH-diesel concentrations greater than $100 \mathrm{mg} / \mathrm{kg}$. The TPH-diesel contaminated soil from the northern and southern sides of the decontamination pad should be segregated from all other excavated material due to the associated low-level radioactive contamination. All excavated material will be disposed of in an appropriate disposal facility. The excavated areas will be returned to surficial conditions compatible with existing operations. The excavation will be backfilled with clean borrow soil.

Under this alternative, soil will be excavated to a depth of $2 \mathrm{ft} b g s$ at the perimeter of the former decontamination pad. Soil in the southwest corner of the pad will be excavated to a depth of $6 \mathrm{ft}$ bgs. Activities will include excavation and proper disposal of approximately $14 \mathrm{yd}^{3}$ of TPH contaminated soil and $5 \mathrm{yd}^{3}$ of TPH and radionuclide contaminated soil. Verification sampling will be performed in approximately the same locations as those identified in the investigation as having COC concentrations exceeding PALs. This will ensure complete removal of TPH contaminated soil at concentrations exceeding the PALs.

The F and J Roads Pad will be closed in accordance with NAC 445A (NAC, 1997b) as described in this section.

\subsection{Evaluation and Comparison of Alternatives}

The general corrective action standards and remedy selection decision factors described in Section 3.2 were used to conduct detailed and comparative analyses of each corrective action alternative. The advantages and disadvantages of each alternative were assessed to select a preferred alternative for the F and J Roads Pad. Table 3-1 presents a summary of the detailed analysis of the alternatives. Table 3-2 presents the comparative analysis of alternatives. Cost summaries are provided in Appendix B. 
Table 3-1

Detailed Evaluation of Alternatives

(Page 1 of 2)

\begin{tabular}{|c|c|c|}
\hline Evaluation Criteria & $\begin{array}{l}\text { Alternative } 1 \\
\text { No Further Action }\end{array}$ & $\begin{array}{c}\text { Alternative } 2 \\
\text { Clean Closure by Excavation and } \\
\text { Disposal }\end{array}$ \\
\hline \multicolumn{3}{|c|}{ Corrective Action Standards } \\
\hline $\begin{array}{l}\text { Protection of Human Health } \\
\text { and the Environment }\end{array}$ & 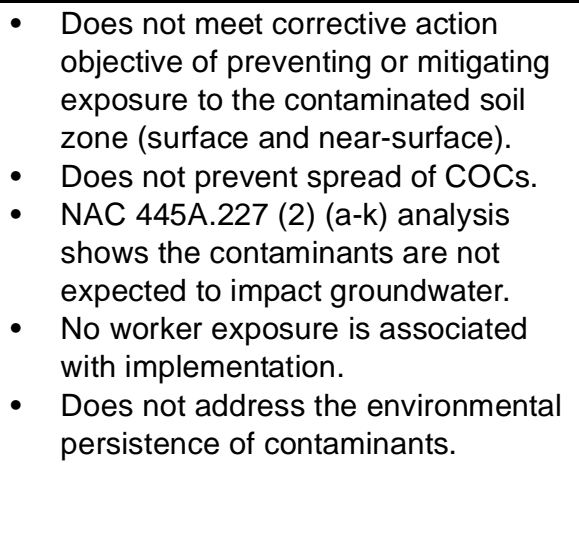 & $\begin{array}{l}\text { - Meets corrective action objectives by } \\
\text { removal of contaminated soil. } \\
\text { - Low worker exposure associated with } \\
\text { fugitive dust and/or contact with } \\
\text { impacted media. } \\
\text { - Low risk to public because of remote } \\
\text { location and controlled access to the } \\
\text { NTS. } \\
\text { NAC 445A.227 (2) (a-k) analysis shows } \\
\text { the contaminants are not expected to } \\
\text { impact groundwater. } \\
\text { Moving contaminated soil to an } \\
\text { appropriate disposal facility addresses } \\
\text { the persistence of contaminants. }\end{array}$ \\
\hline $\begin{array}{l}\text { Compliance with Media } \\
\text { Cleanup Standards }\end{array}$ & $\begin{array}{l}\text { Does not comply with media cleanup } \\
\text { standards because TPH remain at } \\
\text { levels above the PAL, and no } \\
\text { corrective action is taken to prevent } \\
\text { inadvertent intrusion. } \\
\text { - NAC 445A.227 (2) (a-k) analysis } \\
\text { shows the contaminants are not } \\
\text { expected to impact groundwater. }\end{array}$ & $\begin{array}{l}\text { - Complies with media cleanup standards } \\
\text { because soil containing TPH at } \\
\text { concentrations exceeding the PAL will be } \\
\text { excavated and disposed of at an } \\
\text { appropriate facility. } \\
\text { - Removal of TPH concentrations } \\
\text { exceeding the PAL will be verified with } \\
\text { confirmation sampling. } \\
\text { NAC } 445 A .227(2)(a-k) \text { analysis shows } \\
\text { the contaminants are not expected to } \\
\text { impact groundwater. }\end{array}$ \\
\hline $\begin{array}{l}\text { Control the Source(s) of } \\
\text { Release }\end{array}$ & $\begin{array}{l}\text { The sources (decontamination } \\
\text { operations) to the F and J Roads Pad } \\
\text { have been discontinued. }\end{array}$ & $\begin{array}{l}\text { The sources (decontamination } \\
\text { operations) to the F and J Roads Pad } \\
\text { have been discontinued. }\end{array}$ \\
\hline $\begin{array}{l}\text { Comply with Applicable } \\
\text { Federal, State, and Local } \\
\text { Standards for Waste } \\
\text { Management }\end{array}$ & No waste generated & $\begin{array}{l}\text { All waste (primarily contaminated soil, } \\
\text { concrete, and disposable personal protective } \\
\text { equipment) will be handled and disposed of } \\
\text { in accordance with applicable standards. }\end{array}$ \\
\hline \multicolumn{3}{|c|}{ Remedy Selection Decision Factors } \\
\hline $\begin{array}{l}\text { Short-Term Reliability and } \\
\text { Effectiveness }\end{array}$ & Not evaluated & $\begin{array}{l}\text { - Low risk to workers associated with } \\
\text { fugitive dusts and heavy equipment. } \\
\text { - Public protected by remote location and } \\
\text { NTS site access controls. } \\
\text { - Implementation should not require an } \\
\text { extended period of time. }\end{array}$ \\
\hline
\end{tabular}


Table 3-1

Detailed Evaluation of Alternatives

(Page 2 of 2)

\begin{tabular}{|c|c|c|}
\hline Evaluation Criteria & $\begin{array}{l}\text { Alternative } 1 \\
\text { No Further Action }\end{array}$ & $\begin{array}{c}\text { Alternative } 2 \\
\text { Clean Closure by Excavation and } \\
\text { Disposal }\end{array}$ \\
\hline $\begin{array}{l}\text { Reduction of Toxicity, } \\
\text { Mobility, and/or Volume }\end{array}$ & Not evaluated & $\begin{array}{l}\text { - Clean closure would effectively eliminate } \\
\text { associated toxicity, mobility, and volume } \\
\text { of wastes at the F and J Roads Pad. } \\
\text { - Proper disposal of the waste after } \\
\text { removal would result in ultimate } \\
\text { reduction of mobility. }\end{array}$ \\
\hline $\begin{array}{l}\text { Long-Term Reliability and } \\
\text { Effectiveness }\end{array}$ & Not evaluated & $\begin{array}{l}\text { - } \text { All risks will be eliminated upon } \\
\text { completion. } \\
\text { - } \quad \text { No maintenance required. } \\
\text { - } \text { Mond J Roads Pad clean closed. } \\
\text { appropriate disposal facility addresses } \\
\text { the persistent adsorption of } \\
\text { contaminants to the soil. }\end{array}$ \\
\hline Feasibility & Not evaluated & $\begin{array}{l}\text { - Closure of F and J Roads Pad is easily } \\
\text { implemented. }\end{array}$ \\
\hline Cost & $\$ 0$ & $\$ 105,835$ \\
\hline
\end{tabular}


Table 3-2

Comparative Evaluation of Alternatives

\begin{tabular}{|c|c|}
\hline Evaluation Criteria & Comparative Evaluation \\
\hline \multicolumn{2}{|r|}{ Corrective Action Standards } \\
\hline $\begin{array}{l}\text { Protection of Human Health and } \\
\text { the Environment }\end{array}$ & $\begin{array}{l}\text { Alternative } 2 \text { meets corrective action objectives; Alternative } 1 \text { does not. No } \\
\text { worker exposure to risks are associated with Alternative } 1 . \text { Low risks are } \\
\text { associated with Alternative } 2 \text {. NAC } 445 A .227(2)(a-k) \text { analysis shows the } \\
\text { contaminants are not threatening groundwater. }\end{array}$ \\
\hline $\begin{array}{l}\text { Compliance with Media Cleanup } \\
\text { Standards }\end{array}$ & $\begin{array}{l}\text { Alternative } 1 \text { does not comply with media cleanup standards. Alternative } 2 \text { meets } \\
\text { media cleanup standards by removing soil containing TPH at concentrations } \\
\text { exceeding the PAL and eliminating exposure pathways at the site. }\end{array}$ \\
\hline $\begin{array}{l}\text { Control the Source(s) of the } \\
\text { Release }\end{array}$ & $\begin{array}{l}\text { The sources (decontamination operations) to the } \mathrm{F} \text { and } \mathrm{J} \text { Roads Pad have been } \\
\text { discontinued. }\end{array}$ \\
\hline $\begin{array}{l}\text { Comply with Applicable Federal, } \\
\text { State, and Local Standards for } \\
\text { Waste Management }\end{array}$ & $\begin{array}{l}\text { Alternative } 1 \text { does not generate waste. Alternative } 2 \text { will generate waste that will } \\
\text { be handled in accordance with applicable standards. }\end{array}$ \\
\hline \multicolumn{2}{|r|}{ Remedy Selection Decision Factors } \\
\hline $\begin{array}{l}\text { Short-Term Reliability and } \\
\text { Effectiveness }\end{array}$ & Low risks are associated with Alternative 2. \\
\hline $\begin{array}{l}\text { Reduction of Toxicity, Mobility, } \\
\text { and/or Volume }\end{array}$ & $\begin{array}{l}\text { Alternative } 2 \text { results in a reduction of all three characteristics at the } \mathrm{F} \text { and } \mathrm{J} \text { Roads } \\
\text { Pad. }\end{array}$ \\
\hline $\begin{array}{l}\text { Long-Term Reliability and } \\
\text { Effectiveness }\end{array}$ & Residual risk at the $\mathrm{F}$ and $\mathrm{J}$ Roads Pad is nonexistent for Alternative 2 . \\
\hline Feasibility & $\begin{array}{l}\text { Alternative } 2 \text { is feasible. Alternative } 2 \text { requires heavy equipment, operating } \\
\text { personnel, and disposal of wastes. }\end{array}$ \\
\hline Cost & $\begin{array}{l}\text { The cost for Alternative } 1 \text { is } \$ 0 \text {. The estimated cost for Alternative } 2 \text { is } \$ 105,835 \\
\text { for excavation and disposal. }\end{array}$ \\
\hline
\end{tabular}




\subsection{Recommended Alternative}

Based on the results of the detailed and comparative analysis of the potential corrective action alternatives presented in this document, the preferred corrective action alternative selected for implementation at the F and J Roads Pad is Alternative 2, Clean Closure by Excavation and Disposal. Alternative 2 was chosen for the following reasons:

- It minimizes health risks by preventing public and worker access to the contaminated soil at the F and J Roads Pad by moving contaminated soil to an appropriate disposal facility.

- It complies with standards for management of wastes because all waste will be managed in accordance with federal, state, and local requirements.

- It eliminates long-term risks by moving contaminated soil to an appropriate disposal facility.

- It is easily implemented with standard construction equipment utilized for removal of contaminated soil.

- It provides a cost-effective method for achieving protection and meeting closure requirements.

The preferred corrective action alternative was evaluated on its technical merits, focusing on performance, reliability, feasibility, and safety. The alternative was judged to meet all requirements for the technical components evaluated. The alternative meets all applicable state and federal regulations for closure of the site and will eliminate potential future exposure pathways to the contaminated soils at the F and J Roads Pad.

During corrective action implementation, this alternative may potentially present low risks to site workers. Therefore, appropriate health and safety procedures will be developed and implemented.

Based on the evaluation in this CADD, clean closure of the F and J Roads Pad by excavation and disposal is the preferred closure method. 


\subsection{References}

CFR, see Code of Federal Regulations.

Code of Federal Regulations. 1998. Title 40 CFR Parts 260 - 282, "RCRA Regulations."

Washington, DC: U.S. Government Printing Office.

DOE/NV, see U.S. Department of Energy, Nevada Operations Office.

EPA, see U.S. Environmental Protection Agency.

FFACO, see Federal Facility Agreement and Consent Order.

Federal Facility Agreement and Consent Order. 1996 (as amended). Agreed to by the State of Nevada, the U.S. Department of Energy, and the U.S. Department of Defense.

IT Corporation. 1998. Field Activity Daily Log for site visit B. Bordelois and C. Rodriguez to CAU 240, CAS 25-07-01, CAS 25-07-02, and CAS 25-07-03, 28 September. Las Vegas, NV.

Laczniak, R.J., J.C. Cole, D.A. Sawyer, and D.T. Trudeau. 1996. Summary of Hydrogeological Controls on Ground-Water Flow at the Nevada Test Site, Nye County, Nevada, U.S. Geological Survey Water-Resources Investigations Report 96-4109. Denver, CO: U.S. Geological Survey.

NAC, see Nevada Administrative Code.

Nevada Administrative Code. 1997a. NAC 444, "Sanitation.” Carson City, NV.

Nevada Administrative Code. 1997b. NAC 445A, "Water Controls." Carson City, NV.

Nevada Administrative Code. 1997c. NAC 459, "Hazardous Materials.” Carson City, NV.

NRS, see Nevada Revised Statutes.

Nevada Revised Statutes. 1995. NRS 459.400-459.600, “Disposal of Hazardous Waste.” Carson City, NV.

SNPO, see Space Nuclear Propulsion Office.

Space Nuclear Propulsion Office. 1970. NRDS Master Plan 1969-1970, Nuclear Rocket Development Station, Jackass Flats, Nevada. Las Vegas, NV.

U.S. Department of Energy, Nevada Operations Office. 1987. Nevada Test Site - Environmental Compliance Atlas, 15 June. Las Vegas, NV. 
U.S. Department of Energy, Nevada Operations Office. 1994. Project Management Plan, Rev. 0. Las Vegas, NV.

U.S. Department of Energy, Nevada Operations Office. 1996a. Final Environmental Impact Statement for the Nevada Test Site and Off-Site Locations in the State of Nevada, DOE/EIS 0243. Las Vegas, NV.

U.S. Department of Energy, Nevada Operations Office. 1996b. Industrial Sites Quality Assurance Project Plan, Nevada Test Site, Nevada, Rev. 1, DOE/NV--372. Las Vegas, NV.

U.S. Department of Energy, Nevada Operations Office. 1999. Corrective Action Investigation Plan for Corrective Action Unit 240: Area 25 Vehicle Washdown, Nevada Test Site, Nye County, Nevada, Rev. 0, DOE/NV--532. Las Vegas, NV.

U.S. Environmental Protection Agency. 1991. Guidance on RCRA Corrective Action Decision Documents, EPA/540/G-91/011. Washington, DC: Office of Research and Development.

U.S. Environmental Protection Agency. 1994. Final RCRA Corrective Action Plan, EPA/520-R-94-004. Washington, DC: Office of Solid Waste and Emergency Response.

USGS, see U.S. Geological Survey.

U.S. Geological Survey. 1993. Selected Ground-Water Data for Yucca Mountain Region, Southern Nevada and Eastern California, Calendar Year 1993, Open-File Report 95-158.

Winograd, I.J., and W. Thordarson. 1975. Hydrologic and Hydrochemical Framework, South-Central Great Basin, Nevada-California, with Special Reference to the Nevada Test Site, U.S. Geological Survey Professional Paper 712C. Washington, DC: U.S. Government Printing Office. 


\section{Appendix A}

Corrective Action Investigation Report for CAU 240: Area 25 Vehicle Washdown, Nevada Test Site, Nevada 


\section{A.1.0 Introduction}

This appendix presents corrective action investigation activities and analytical results for Area 25 Vehicle Washdown, CAU 240, at the NTS. The Area 25 Vehicle Washdown CAU includes CAS 25-07-01, Vehicle Washdown Area (Propellant Pad); CAS 25-07-02, Vehicle Washdown Area (F and J Roads Pad); and CAS 25-07-03, Vehicle Washdown Station (RADSAFE Pad). The corrective action investigation was conducted in accordance with the CAIP (DOE/NV, 1999) as developed under the FFACO (1996).

The Area 25 Vehicle Washdown CASs were investigated because limited process knowledge indicated that reactor parts, parts associated with reactors, and beagles may have been decontaminated at these facilities. Preliminary analytical results indicated the presence of pesticides in the surface soil at these sites. Additional information regarding the history of each site, planning, and the scope of the investigation is presented in the CAIP (DOE/NV, 1999) and will not be repeated in this report.

\section{A.1.1 Project Objectives}

The primary objectives of the investigation were as described below:

- Identify the presence and the vertical and lateral extent of COPCs.

- Provide sufficient information and data to develop appropriate corrective action alternatives for the Area 25 Vehicle Washdown.

The selection of soil sample locations for the three sites was based on site conditions and the strategy developed during the DQO process as outlined in the CAIP (DOE/NV, 1999).

\section{A.1.2 Report Content}

This report contains information and data in sufficient detail to support the selection of a preferred corrective action alternative in the CADD. The contents of this report are as follows:

- Section A.1.0 describes the investigation background, objectives, and the report content.

- Section A.2.0 provides information regarding the field activities and sampling methods. 
- Section A.3.0 summarizes the results of the laboratory analyses from the investigation sampling.

- Section A.4.0 discusses the quality assurance (QA) and quality control (QC) procedures that were followed and the results of the QA/QC activities.

- Section A.5.0 is a summary of the investigation results.

- Section A.6.0 provides the cited references.

The complete field documentation and laboratory data, including Field Activity Daily Logs, Sample Collection Logs, Analysis Request/Chain-of-Custody Forms, soil sample descriptions, laboratory certificates of analyses, analytical results, and surveillance results are retained in project files as either hard copy files or electronic media. 


\section{A.2.0 Field Investigation and Sampling Activities}

The field investigation and sampling activities were conducted from March 1 through March 17, 1999, at the three CASs within CAU 240, Area 25 Vehicle Washdown.

Sampling activities at CAS 25-07-01 (Propellant Pad) were performed using a direct-push method $\left(\right.$ Geoprobe $^{\circledR}$ ) for the collection of soil samples from 0 to $1 \mathrm{ft}$ bgs (surface) and 3 to $5 \mathrm{ft}$ bgs (near-surface). The 10 planned samples were collected and sent to the laboratories for analyses. In step-out samples, the first of the two consecutive, nondetect intervals was sent to the laboratories for analyses.

At CAS 25-07-03 (RADSAFE Pad), a video mole survey was conducted to determine the condition and extent of the asbestos-cement pipe located at the northwest corner of the concrete pad and to determine the condition and extent of the pipe from the metal vault at the northeast corner of the concrete pad. The 18 planned samples were collected from 0 to $1 \mathrm{ft}$ and 3 to $5 \mathrm{ft}$ bgs using a direct-push method $\left(\right.$ Geoprobe $\left.^{\circledR}\right)$ and submitted to the laboratories for analyses. Step-outs were not necessary at this CAS.

At CAS 25-07-02 (F and J Roads Pad), a video mole survey was conducted to determine the condition and extent of the pipe from the pad to the gravel sump. The 16 planned samples outside of the gravel sump were collected from 0 to $1 \mathrm{ft}$ and 3 to $5 \mathrm{ft}$ bgs using a direct-push method (Geoprobe ${ }^{\circledR}$ ) and submitted to the laboratories for analyses. The six planned samples in the gravel sump were collected from 0 to $1 \mathrm{ft}$ and 1 to $2 \mathrm{ft}$ below the gravel/soil interface using a backhoe. In step-out samples, the first of the two consecutive, nondetect intervals was sent to the laboratories for analyses.

The field investigation and sampling program was managed in accordance with the requirements set forth in the CAIP (DOE/NV, 1999). The field activities were performed in accordance with an approved Site-Specific Health and Safety Plan (IT, 1998b). The samples were collected and documented by following approved protocols and procedures for sampling, field activity and sample collection documentation, decontamination, chain of custody, shipping, and radiation survey as indicated in the CAIP (DOE/NV, 1999). Quality control samples (e.g., field blanks, equipment rinsate blanks, trip blanks, and sample duplicates) were collected as required by the Industrial Sites 
Quality Assurance Project Plan (DOE/NV, 1996) and approved procedures. During field activities, waste minimization practices were followed according to approved procedures, including segregation of the waste by waste stream.

\section{A.2.1 Site Descriptions and Conditions}

Area 25 Vehicle Washdown is located in the Nuclear Rocket Development Station (NRDS) area on the NTS (see Figure 1-2 of the CADD). The three CASs are located in an area that is relatively flat.

Propellant Pad is located in the Central Propellant Support Area (CPSA), east of Building 4839, along 2nd Street. Running water from a faucet located on the east side of the concrete pad was observed at the beginning of the investigation. The concrete pad is surrounded by soil to the east and west sides and has an asphalt road to the south and north of the concrete pad.

The RADSAFE Pad is located east of the intersections of Jackass Flats Road and Cane Springs Road, on the north side of Cane Springs Road, directly behind the RADSAFE Building (Building 3152). The RADSAFE Pad site consists of a concrete pad with a drain/trench covered by a metal grate located along the north edge of the concrete pad. A cleanout pipe is located near the northeast corner of the concrete pad. This pipe is connected to the asbestos-cement pipe located at the northwest corner of the concrete pad which extends approximately $100 \mathrm{ft}$ northwest of the concrete pad. At the end of this pipe is a dry well consisting of a gravel pit. Located along the south edge of the RADSAFE Pad is a concrete pad historically used for drum storage and an associated ramp.

The F and J Roads Pad is located at the southwest corner of the intersection of the F and J Roads. The site consists of a concrete washdown pad, a gravel sump along the west side of the pad, two concrete trailer pads located east of the concrete pad, and remaining piping system. Prior to the start of sampling activities, the pad and eastern side of the gravel sump was fenced and posted as a soil contamination area.

During the investigation, the weather conditions at the sites were generally favorable and varied from sunny to intermittent cloudiness and light to strong winds. Strong winds impacted one day of sampling activities during the field investigation at F and J Roads Pad. 
Soil conditions at these sites made sample collection difficult. The very soft and fine materials encountered (i.e., silts and sands) caused sandlocking during core retrieval, and caused the direct-push holes to collapse. At the greater depths (above $5 \mathrm{ft}$ ), very compacted soils were encountered, causing difficulty in the penetration of the Geoprobe ${ }^{\circledR}$ core barrels. In addition to sample collection difficulties, road closures, personnel training, and health and safety concerns impacted the schedule of this field investigation.

\section{A.2.2 Investigation Logistics}

This section describes sample collection and investigation activities for each of the CASs in CAU 240, Area 25 Vehicle Washdown.

\section{A.2.2.1 Sample Locations}

The sampling locations for each site were selected based on process knowledge, engineering drawings, interviews, and in the case of step-outs, field-screening results. The planned sample locations are shown in the CAIP (DOE/NV, 1999). Some locations vary slightly from those planned because of field observations or conditions encountered during sampling. Actual sample locations are shown in Figure A.2-1, Figure A.2-2, and Figure A.2-3.

\section{A.2.2.2 Excavation Activities}

Excavation activities were performed with a backhoe to expose the junction of the asbestos-cement pipe and the cleanout pipe, and to expose the dry well location at the RADSAFE Pad. In addition, the backhoe was used to perform backhoe bucket sampling at the F and J Roads Pad gravel sump. The backhoe was also used to retrieve a core barrel from depth at the F and J Roads Pad.

\section{A.2.2.3 Video Survey Activities}

Video surveys were conducted at the RADSAFE Pad and the F and J Roads Pad. These surveys were conducted to identify obvious breaches, unexpected branchings (i.e., tie-ins or off-shoots), and open joints.

The surveys at both the RADSAFE Pad and F and J Roads Pad were inconclusive. The pipes at the RADSAFE Pad were found to be full of mouse nests and droppings. Due to the health risks 


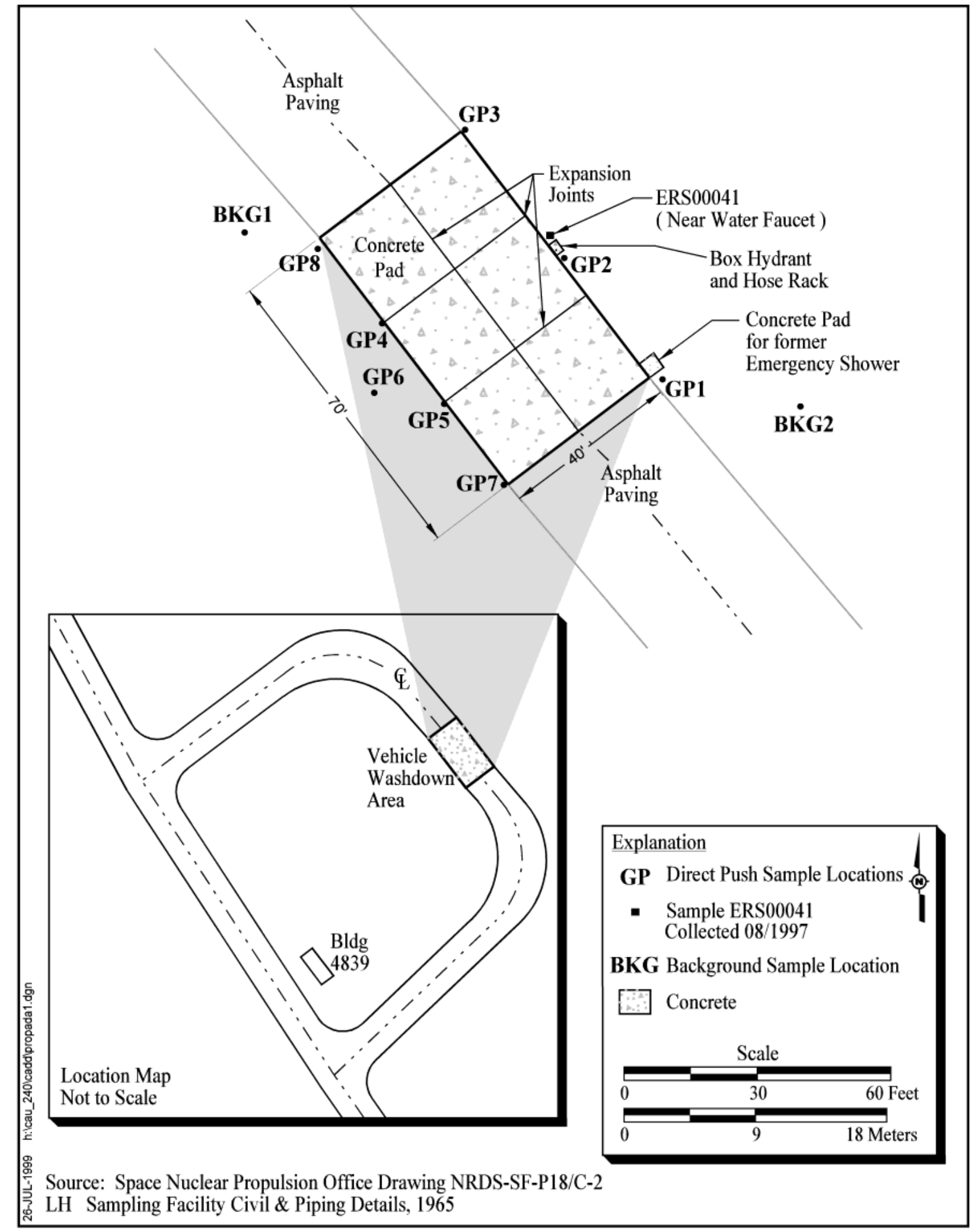

Figure A.2-1

Sample Locations at CAS 25-07-01, Vehicle Washdown Area (Propellant Pad), Area 25, Nevada Test Site 


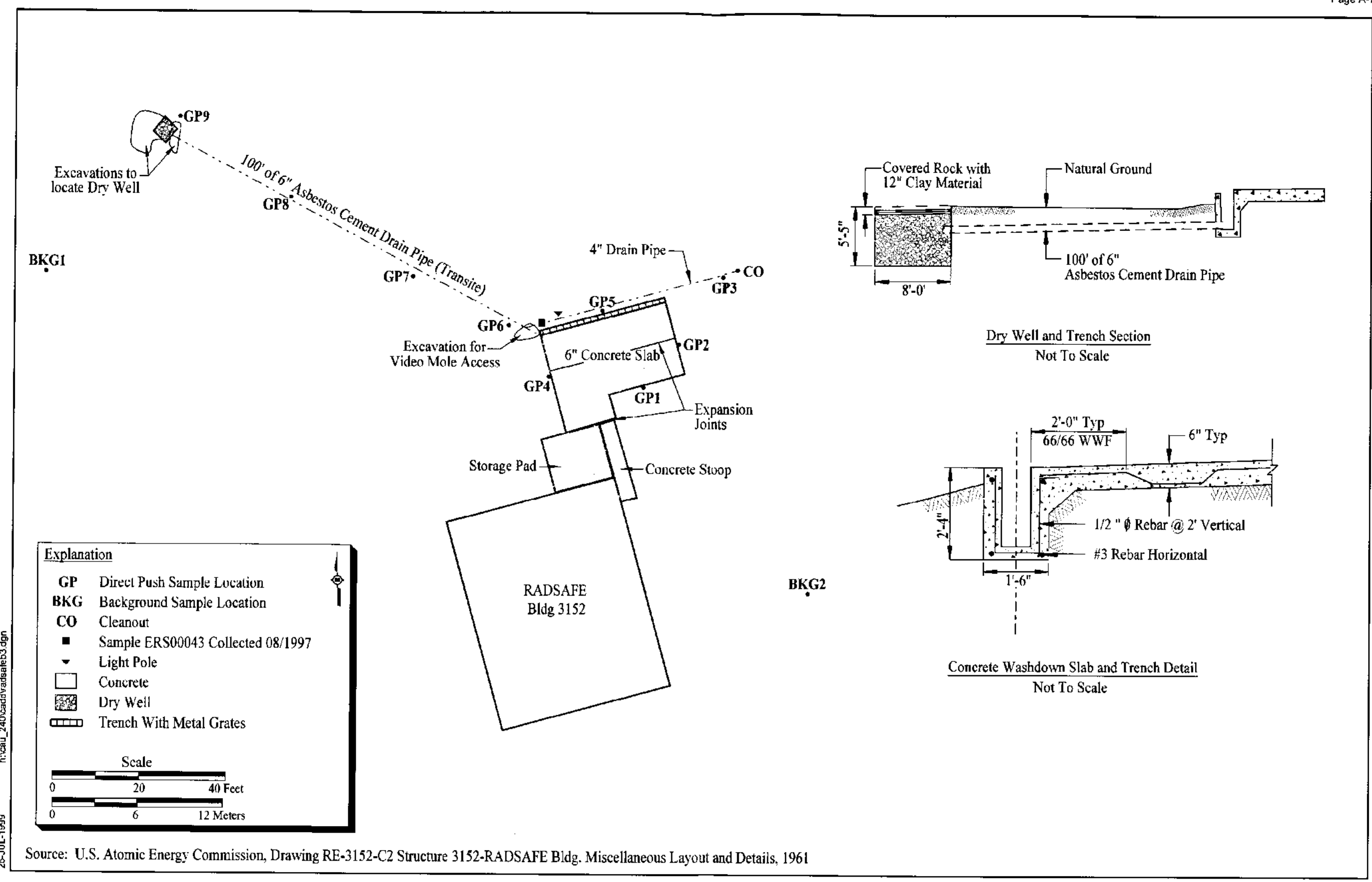

Figure A.2-2

Sample Locations at CAS 25-07-03, Vehicle Washdown Station (RADSAFE Pad), Area 25, Nevada Test Site 


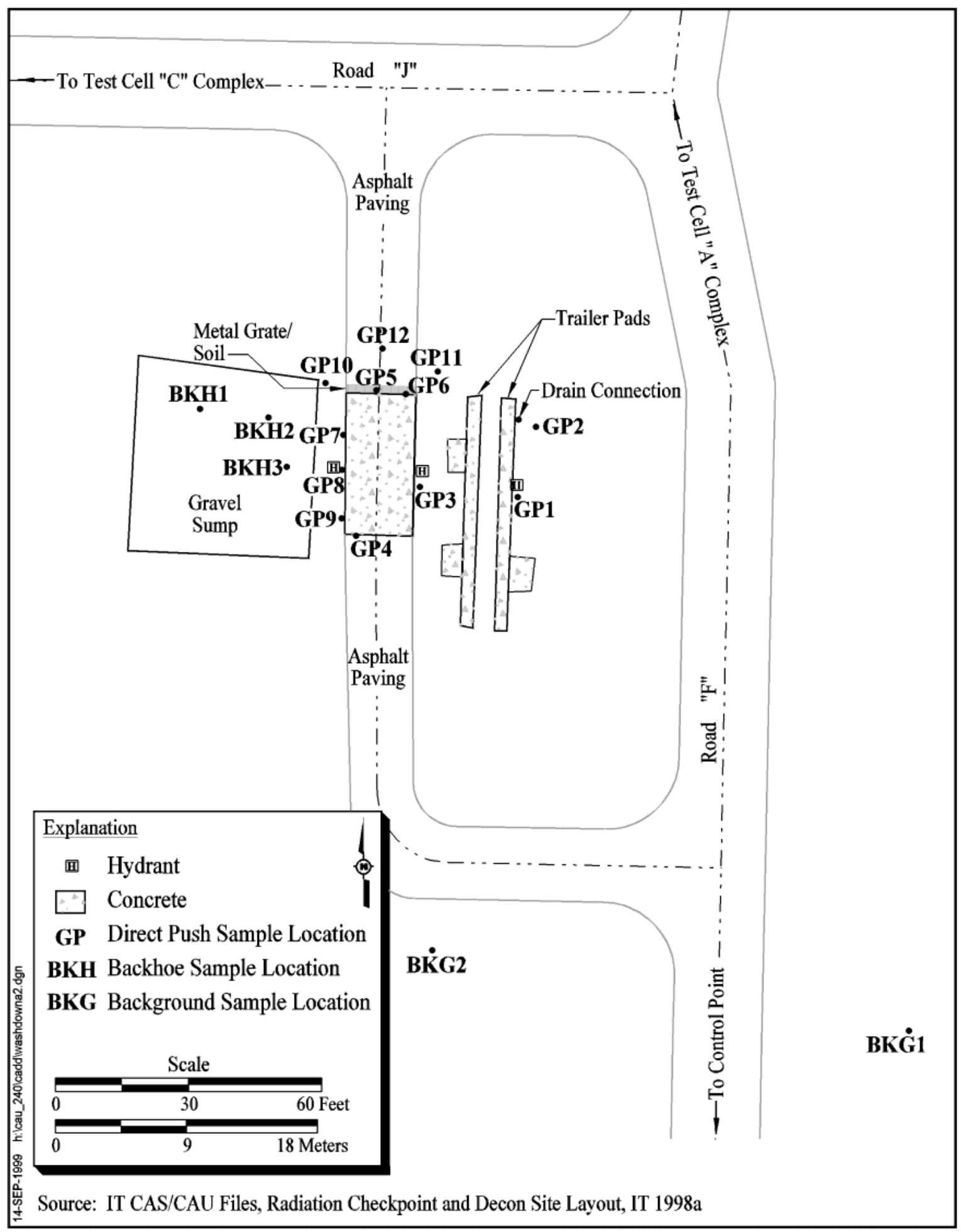

Figure A.2-3

Sample Locations at CAS 25-07-02, Vehicle Washdown Area (F and J Roads Pad), Area 25, Nevada Test Site 
associated with mouse droppings (hantavirus), the video mole survey at this pipe was discontinued. The drain pipe was observed for about $10 \mathrm{ft}$ and then found to be full of soil, blocking the path and view of the camera survey. At the F and J Roads Pad, a survey was attempted from the sewer pipe located in the gravel sump towards the eastern edge of the CAS. Using the video camera, it was discovered that the diameter of the sewer pipe became significantly smaller after approximately $38 \mathrm{ft}$, thereby restricting the progress of the video camera equipment.

\section{A.2.2.4 Direct-Push Sampling}

A direct-push method $\left(\right.$ Geoprobe $^{\circledR}$ ) was used to collect samples at the Area 25 Vehicle Washdown CASs from 0 to $1 \mathrm{ft}, 3$ to $5 \mathrm{ft}, 5$ to $7 \mathrm{ft}$, and 7 to $9 \mathrm{ft}$ bgs. Soil samples were collected using a Macrocore ${ }^{\circledR}$ sampler ( 2 in. outside diameter) with stainless-steel or polyvinyl chloride (PVC) liners.

At the conclusion of the field investigation, all remaining voids from direct-push sampling were backfilled with bentonite.

\section{A.2.2.5 Field-Screening}

Field-screening activities were performed as specified in the CAIP (DOE/NV, 1999).

Field-screening levels were determined for VOCs (headspace method using a photoionization detector and a water bath at constant temperature), and for radiation (alpha and beta using an Electra and gamma using a sodium iodide detector). The field-screening level for VOC headspace was established at 20 parts per million ( $\mathrm{ppm}$ ) or 2.5 times background, whichever was greater. The field-screening level for radiation was defined as the mean background activity level plus two times the standard deviation of 20 background sample readings. The radiological field-screening levels were determined prior to the start of field activities. Established field-screening levels were used to guide sample collection both laterally and vertically and to provide a basis for the selection of additional environmental samples for laboratory analyses.

\section{A.2.3 Sample Collection}

Sample collection was performed as specified in the CAIP (DOE/NV, 1999). Samples were collected as planned from the 0 to $1 \mathrm{ft}$ and 3 to $5 \mathrm{ft}$ bgs intervals. When field-screening results exceeded field-screening levels, samples were collected at the 5 to $7 \mathrm{ft}$ and the 7 to $9 \mathrm{ft}$ bgs intervals or until two 
consecutive samples were collected with field-screening results below field-screening levels. Sample collection was also performed within the gravel sump of the F and J Roads Pad using the backhoe method. At the gravel sump, samples were collected at the 0 to $1 \mathrm{ft}$ and 1 to $2 \mathrm{ft}$ interval. The depth interval at each sample location varied depending on whether the location was used for identification of lateral and/or vertical extent of the contaminants of potential concern (for example, at some locations only the 0 to $1 \mathrm{ft}$ and 3 to $5 \mathrm{ft}$ intervals were sampled) and at other locations additional intervals (for example, the 5 to $7 \mathrm{ft}$ and 7 to $9 \mathrm{ft}$ ) were sampled. Soil descriptions performed by the sampling team were recorded on Sample Collection Logs which are located in the project files.

The samples were removed from the liners for the aforementioned intervals and placed into the appropriate containers. The VOC and headspace soil samples were immediately placed into jars and sealed. The headspace sample, used for field-screening purposes, was then placed in a water bath. The soil samples for the SVOCs, RCRA metals, PCBs, pesticides, and radionuclides analyses were homogenized in a steel bowl, containerized, and sealed.

\section{A.2.3.1 CAS 25-07-01, Propellant Pad}

Process knowledge indicated that prior activities at the Propellant Pad included sampling of gases and liquid gases as the dewars arrived at the NRDS from the supplier. Sampling was performed prior to releasing the gases and liquid gases to the test cells in the NRDS. Liquid gases and gases such as propane, helium, nitrogen, and oxygen may also have been sampled at the CPSA. The use of the Propellant Pad for sampling gases and liquid gases probably continued through 1973, until the nuclear rocket tests at the NRDS were terminated.

Nineteen surface and near-surface soil samples were collected from eight locations using the direct-push method. Sixteen soil samples were sent to off-site laboratories for analyses (Table A.3-1). Ten samples were planned to be submitted to the laboratories for this CAS. Two additional samples were submitted to the laboratories for analyses from the 5 to $7 \mathrm{ft}$ intervals at the GP4 and GP5 locations as shown in Figure A.2-1. Three additional stepout samples (GP6, GP7, and GP8) were submitted to the laboratories for analyses from the 0 to $1 \mathrm{ft}$ interval. The remaining three samples were collected but not analyzed. These samples were the second of two consecutive, nondetect intervals and since no contamination was detected above field-screening levels, only the first of the 
two consecutive samples below field-screening levels were required to be submitted to the laboratories for confirmation of the nondetect field-screening readings.

\section{A.2.3.2 CAS 25-07-03, RADSAFE Pad}

Process knowledge indicated that the RADSAFE Building and Pad were originally designed as a radiation checkpoint and decontamination area for the NRDS and are believed to have been in operation from 1959, when the NRDS began operation, until the 1973 termination of the NRDS program. The washdown pad was originally intended to be a radiation control area and occasional decontamination facility. Vehicles reentering the test cell and reactor facilities were decontaminated at the RADSAFE Pad. Also, parts associated with reactor runs were believed to have been decontaminated at the RADSAFE Pad (Sorom, 1998).

Nineteen soil samples were collected (by direct-push) from nine locations (Figure A.2-2); all 19 of these samples were sent to an off-site laboratories for analyses (Table A.3-1). Field-screening results did not exceed field-screening levels for any of the samples collected at this CAS.

\section{A.2.3.3 CAS 25-07-02, F and J Roads Pad}

Process knowledge indicated that the $\mathrm{F}$ and $\mathrm{J}$ Roads Pad was used as a radiation checkpoint and decontamination site. Historical information regarding the operation of the F and $\mathrm{J}$ Roads Pad is limited. Interviews with former workers at the NRDS indicate that the site was operated by Pan American Corporation during the 1960s and early 1970s. Based on this information, the site is believed to have been used to decontaminate vehicles and possibly disassembled engine and reactor parts from Test Cell C. It is unknown how often this site was used. Due to a lack of visible drains leading from the pad to the gravel sump and the washdown pad sloping to the west towards the gravel sump, it is believed that the liquid from the decontamination activities flowed from the concrete pad into the gravel sump.

Twenty-six soil samples were collected (by direct-push) from 12 locations (Figure A.2-3); 29 of these samples were sent to off-site laboratories for analyses. Due to field-screening results exceeding field-screening levels, samples were collected from three step-out locations (GP10, GP11, and GP12), as well as four additional depth intervals at GP5 and GP6 (5 to $7 \mathrm{ft}$ and 7 to $9 \mathrm{ft}$ ). Of these 
four additional intervals, only the 5 to $7 \mathrm{ft}$ interval at GP5 and GP6 was submitted to the laboratories (two samples) for analyses because this interval constituted the first of two consecutive, nondetect intervals. The step-out intervals were 0 to $1 \mathrm{ft}$ and 3 to $5 \mathrm{ft}$. Of these additional six samples, only three were submitted to the laboratories for analyses, namely the 0 to $1 \mathrm{ft}$ interval at each step-out. This interval constituted the first of two consecutive, nondetect intervals (Figure A.2-3).

Surface sampling at 0 to $1 \mathrm{ft}$ and near-surface sampling at 1 to $2 \mathrm{ft}$ was conducted using a backhoe bucket and hand tools (spoons, bowls etc.) in the gravel sump located at the F and J Roads Pad. The samples were collected from the center of the backhoe bucket after removing the top 1-in. layer of soil. These samples were analyzed for VOCs, SVOCs, RCRA metals, PCBs, pesticides, TPH-diesel/oil, and radionuclides (same analyses used for the samples collected using the direct-push method).

\section{A.2.3.4 Background Sampling}

Background surface and near-surface samples were collected from two undisturbed background locations at each CAS (see Figures A.2-1, A.2-2, and A.2-3). Analytical results of the background samples were used to evaluate environmental sample results and to support the corrective action at this CAU. Background samples were collected from 0 to $1 \mathrm{ft}$ and 3 to $5 \mathrm{ft}$ bgs using the direct-push method. Background samples were sent to the laboratories to be analyzed for RCRA metals, gamma emitters using gamma spectrometry, strontium-90, and isotopic uranium and plutonium as detailed in Table A.3-4 in Appendix A of the CAIP (DOE/NV, 1999).

\section{A.2.4 Geology}

Corrective Action Unit 240 is located in Jackass Flats. The Jackass Flats basin was formed by faulting of Paleozoic carbonate rocks. The Paleozoic rock and clastic sediment are approximately $22,000 \mathrm{ft}$ thick and are overlain by welded and semiwelded ash flow and ash fall tuffs of Tertiary age, approximately 5,000 ft thick. The most prominent structural feature in Jackass Flats is a fault which trends northeast and is located west of Well J-11. Surface geology and soils in Area 25 consist of silty sand, ranging from fine sand to coarse sand and gravel. These types of soils are generally unstable and cohesionless. Other rock types in the surrounding area include shales, quartzites, and carbonates of Lower to Middle Cambrian age; carbonate and thin shale layers of Middle Cambrian to 
Devonian age; and argillites, cherty limestones, and conglomerates of Devonian to Permian age. Soils in the area range from poorly sorted silt to coarse sand and gravel (SNPO, 1970).

\section{A.2.5 Hydrology}

Depth to groundwater at the NRDS Facility and vehicle washdown stations ranges from 700 to 1,700 ft. Yucca Flats, Frenchman Flats, and Jackass Flats are believed to be hydraulically connected, with groundwater moving through fracture zones in carbonate strata. Groundwater flow is generally to the southwest and may discharge at Ash Meadows, located approximately $35 \mathrm{mi}$ southwest of Yucca Flats (SNPO, 1970). Groundwater at Well J-11, the nearest well to the F and J Roads Pad, is approximately $1,040 \mathrm{ft}$. This well is located approximately 14,900 ft southwest of the F and J Roads Pad (USGS, 1993). Wells J-12 and J-13 are also nearby wells. Water from these wells is derived from an aquifer approximately 591 to $1,138 \mathrm{ft}$ deep at Well J-12 and 679 to 1,476 ft deep at Well J-13 (DOE/NV, 1988). There are no perennial surface water sources at the any of the CAU 240, Area 25 Vehicle Washdown CASs that would impact the investigation sites. 


\section{A.3.0 Investigation Results}

The analytical results of samples collected from the CAU 240 investigation have been compiled and evaluated to determine the presence and/or extent of contamination. The analytical results that are above the minimum reporting limits are summarized in the following subsections. The complete laboratory result data packages are available in the project files.

During investigation activities, 79 soil and 39 water samples were submitted for analyses. All raidoanalyses except 43 strontium-90 analyses were performed by Bechtel Nevada Analytical Services, Las Vegas, Nevada. All other analyses were performed by Paragon Analytics, Inc., Fort Collins, Colorado. A list of the samples collected and analyzed for the investigation are presented in Table A.3-1. The analytical parameters and laboratories' analytical methods requested for this investigation are presented in Table A.3-2.

Table A.3-1

Samples Collected During the CAU 240 Area 25 Vehicle Washdown
Corrective Action Investigation

(Page 1 of 6)

\begin{tabular}{|c|c|c|c|c|c|}
\hline $\begin{array}{l}\text { Sample } \\
\text { Number }\end{array}$ & $\begin{array}{l}\text { Sample } \\
\text { Location }\end{array}$ & $\begin{array}{l}\text { Depth } \\
\text { (ft bgs) }\end{array}$ & $\begin{array}{l}\text { Sample } \\
\text { Matrix }\end{array}$ & $\begin{array}{l}\text { Quality Control } \\
\text { Comments }\end{array}$ & Parameters Analyzed \\
\hline \multicolumn{6}{|c|}{ CAS 25-07-01 Propellant Pad } \\
\hline VWDPP001 & BKG1 & $0-1$ & Soil & Background Sample & RCRA Metals, Gamma, Pu, U, Sr-90 \\
\hline VWDPP002 & BKG1 & $3-5$ & Soil & Background Sample & RCRA Metals, Gamma, Pu, U, Sr-90 \\
\hline VWDPP003 & BKG2 & $0-1$ & Soil & Background Sample & RCRA Metals, Gamma, Pu, U, Sr-90 \\
\hline VWDPP004 & BKG2 & $3-5$ & Soil & Background Sample & RCRA Metals, Gamma, Pu, U, Sr-90 \\
\hline VWDPP005 & NA & NA & Water & Equipment Blank & $\begin{array}{l}\text { VOCs, SVOCs, RCRA Metals, PCBs, } \\
\text { Pesticides, Gamma, Sr-90 }\end{array}$ \\
\hline VWDPP006 & NA & NA & Water & Field Blank & $\begin{array}{l}\text { VOCs, SVOCs, RCRA Metals, PCBs, } \\
\text { Pesticides, Gamma, Sr-90 }\end{array}$ \\
\hline VWDPP007 & NA & NA & Water & Source Blank & $\begin{array}{l}\text { VOCs, SVOCs, RCRA Metals, PCBs, } \\
\text { Pesticides, Gamma, Sr-90 }\end{array}$ \\
\hline VWDPP008 & GP1 & $0-1$ & Soil & Environmental Sample & VOCs, SVOCs, PCBs, Pesticides, Gamma \\
\hline VWDPP009 & GP1 & $3-5$ & Soil & Environmental Sample & VOCs, SVOCs, PCBs, Pesticides, Gamma \\
\hline VWDPP010 & GP2 & $0-1$ & Soil & Environmental Sample & VOCs, SVOCs, PCBs, Pesticides, Gamma \\
\hline VWDPP011 & GP2 & $3-5$ & Soil & Environmental Sample & VOCs, SVOCs, PCBs, Pesticides, Gamma \\
\hline VWDPP012 & GP3 & $0-1$ & Soil & Environmental Sample & VOCs, SVOCs, PCBs, Pesticides, Gamma \\
\hline VWDPP013 & GP3 & $3-5$ & Soil & Environmental Sample & VOCs, SVOCs, PCBs, Pesticides, Gamma \\
\hline VWDPP014 & GP4 & $0-1$ & Soil & Environmental Sample & VOCs, SVOCs, PCBs, Pesticides, Gamma \\
\hline
\end{tabular}


Table A.3-1

\section{Samples Collected During the CAU 240 Area 25 Vehicle Washdown} Corrective Action Investigation

(Page 2 of 6 )

\begin{tabular}{|c|c|c|c|c|c|}
\hline $\begin{array}{l}\text { Sample } \\
\text { Number }\end{array}$ & $\begin{array}{c}\text { Sample } \\
\text { Location }\end{array}$ & $\begin{array}{l}\text { Depth } \\
\text { (ft bgs) }\end{array}$ & $\begin{array}{l}\text { Sample } \\
\text { Matrix }\end{array}$ & $\begin{array}{l}\text { Quality Control } \\
\text { Comments }\end{array}$ & Parameters Analyzed \\
\hline VWDPP015 & GP4 & $3-5$ & Soil & Environmental Sample & VOCs, SVOCs, PCBs, Pesticides, Gamma \\
\hline VWDPP016 & GP4 & $3-5$ & Soil & $\begin{array}{l}\text { Field Duplicate of } \\
\text { VWDPP015 }\end{array}$ & VOCs, SVOCs, PCBs, Pesticides, Gamma \\
\hline VWDPP017 & GP5 & $0-1$ & Soil & Environmental Sample & VOCs, SVOCs, PCBs, Pesticides, Gamma \\
\hline VWDPP018 & GP5 & $3-5$ & Soil & Environmental Sample & VOCs, SVOCs, PCBs, Pesticides, Gamma \\
\hline VWDPP019 & NA & NA & Water & Trip Blank & VOCs \\
\hline VWDPP020 & NA & NA & Water & Trip Blank & VOCs \\
\hline VWDPP021 & NA & NA & Water & Trip Blank & VOCs \\
\hline VWDPP022 & NA & NA & Water & Trip Blank & VOCs \\
\hline VWDPP023 & NA & NA & Water & Trip Blank & VOCs \\
\hline VWDPP024 & NA & NA & Water & Trip Blank & VOCs \\
\hline VWDPP025 & GP4 & $5-7$ & Soil & Environmental Sample & VOCs, SVOCs, PCBs, Pesticides, Gamma \\
\hline VWDPP027 & GP5 & $5-7$ & Soil & Environmental Sample & VOCs, SVOCs, PCBs, Pesticides, Gamma \\
\hline VWDPP028 & GP6 & $0-1$ & Soil & Environmental Sample & VOCs, SVOCs, PCBs, Pesticides, Gamma \\
\hline VWDPP030 & GP7 & $0-1$ & Soil & Environmental Sample & VOCs, SVOCs, PCBs, Pesticides, Gamma \\
\hline VWDPP032 & GP8 & $0-1$ & Soil & Environmental Sample & VOCs, SVOCs, PCBs, Pesticides, Gamma \\
\hline \multicolumn{6}{|c|}{ CAS 25-07-02 F and J Roads Pad } \\
\hline VWDFJ001 & BKG1 & $0-1$ & Soil & Background Sample & RCRA Metals, Gamma, Pu, U, Sr-90 \\
\hline VWDFJ002 & BKG1 & $3-5$ & Soil & Background Sample & RCRA Metals, Gamma, Pu, U, Sr-90 \\
\hline VWDFJ003 & BKG2 & $0-1$ & Soil & Background Sample & RCRA Metals, Gamma, Pu, U, Sr-90 \\
\hline VWDFJ004 & BKG2 & $3-5$ & Soil & Background Sample & RCRA Metals, Gamma, Pu, U, Sr-90 \\
\hline VWDFJ005 & GP1 & $0-1$ & Soil & Environmental Sample & $\begin{array}{l}\text { VOCs, SVOCs, TPH (Diesel/Oil), RCRA } \\
\text { Metals, PCBs, Pesticides, Gamma, Sr-90 }\end{array}$ \\
\hline VWDFJ006 & GP1 & $3-5$ & Soil & $\begin{array}{l}\text { Environmental Sample } \\
\text { MS/MSD }\end{array}$ & $\begin{array}{l}\text { VOCs, SVOCs, TPH (Diesel/Oil), RCRA } \\
\text { Metals, PCBs, Pesticides, Gamma, Sr-90 }\end{array}$ \\
\hline VWDFJ007 & GP2 & $0-1$ & Soil & Environmental Sample & $\begin{array}{l}\text { VOCs, SVOCs, TPH (Diesel/Oil), RCRA } \\
\text { Metals, PCBs, Pesticides, Gamma, Sr-90 }\end{array}$ \\
\hline VWDFJ008 & GP2 & $3-5$ & Soil & Environmental Sample & $\begin{array}{l}\text { VOCs, SVOCs, TPH (Diesel/Oil), RCRA } \\
\text { Metals, PCBs, Pesticides, Gamma, Sr-90 }\end{array}$ \\
\hline VWDFJ009 & GP3 & $0-1$ & Soil & Environmental Sample & $\begin{array}{l}\text { VOCs, SVOCs, TPH (Diesel/Oil), RCRA } \\
\text { Metals, PCBs, Pesticides, Gamma, Sr-90 }\end{array}$ \\
\hline VWDFJ010 & GP3 & $3-5$ & Soil & Environmental Sample & $\begin{array}{l}\text { VOCs, SVOCs, TPH (Diesel/Oil), RCRA } \\
\text { Metals, PCBs, Pesticides, Gamma, Sr-90 }\end{array}$ \\
\hline VWDFJX10 & GP3 & $3-5$ & Soil & $\begin{array}{l}\text { Field Duplicate of } \\
\text { VWDFJ010 }\end{array}$ & $\begin{array}{l}\text { VOCs, SVOCs, TPH (Diesel/Oil), RCRA } \\
\text { Metals, PCBs, Pesticides, Gamma, Sr-90 }\end{array}$ \\
\hline VWDFJ011 & GP4 & $0-1$ & Soil & Environmental Sample & $\begin{array}{l}\text { VOCs, SVOCs, TPH (Diesel/Oil), RCRA } \\
\text { Metals, PCBs, Pesticides, Gamma, Sr-90 }\end{array}$ \\
\hline
\end{tabular}


Table A.3-1

\section{Samples Collected During the CAU 240 Area 25 Vehicle Washdown Corrective Action Investigation}

(Page 3 of 6 )

\begin{tabular}{|c|c|c|c|c|c|}
\hline $\begin{array}{l}\text { Sample } \\
\text { Number }\end{array}$ & $\begin{array}{c}\text { Sample } \\
\text { Location }\end{array}$ & $\begin{array}{l}\text { Depth } \\
\text { (ft bgs) }\end{array}$ & $\begin{array}{l}\text { Sample } \\
\text { Matrix }\end{array}$ & $\begin{array}{l}\text { Quality Control } \\
\text { Comments }\end{array}$ & Parameters Analyzed \\
\hline VWDFJ012 & GP4 & $3-5$ & Soil & Environmental Sample & $\begin{array}{l}\text { VOCs, SVOCs, TPH (Diesel/Oil), RCRA } \\
\text { Metals, PCBs, Pesticides, Gamma, Sr-90 }\end{array}$ \\
\hline VWDFJ013 & GP5 & $0-1$ & Soil & Environmental Sample & $\begin{array}{c}\text { VOCs, SVOCs, TPH (Diesel/Oil), RCRA } \\
\text { Metals, PCBs, Pesticides, Gamma, Pu, U, } \\
\text { Sr-90 }\end{array}$ \\
\hline VWDFJ014 & GP5 & $3-5$ & Soil & Environmental Sample & $\begin{array}{l}\text { VOCs, SVOCs, TPH (Diesel/Oil), RCRA } \\
\text { Metals, PCBs, Pesticides, Gamma, Sr-90 }\end{array}$ \\
\hline VWDFJ015 & GP6 & $0-1$ & Soil & Environmental Sample & $\begin{array}{l}\text { VOCs, SVOCs, TPH (Diesel/Oil), RCRA } \\
\text { Metals, PCBs, Pesticides, Gamma, Sr-90 }\end{array}$ \\
\hline VWDFJ016 & GP6 & $3-5$ & Soil & Environmental Sample & $\begin{array}{l}\text { VOCs, SVOCs, TPH (Diesel/Oil), RCRA } \\
\text { Metals, PCBs, Pesticides, Gamma, Sr-90 }\end{array}$ \\
\hline VWDFJ017 & GP7 & $0-1$ & Soil & Environmental Sample & $\begin{array}{l}\text { VOCs, SVOCs, TPH (Diesel/Oil), RCRA } \\
\text { Metals, PCBs, Pesticides, Gamma, Sr-90 }\end{array}$ \\
\hline VWDFJ018 & GP7 & $3-5$ & Soil & Environmental Sample & $\begin{array}{l}\text { VOCs, SVOCs, TPH (Diesel/Oil), RCRA } \\
\text { Metals, PCBs, Pesticides, Gamma, Sr-90 }\end{array}$ \\
\hline VWDFJ019 & GP7 & $3-5$ & Soil & $\begin{array}{l}\text { Field Duplicate of } \\
\text { VWDFJ018 }\end{array}$ & $\begin{array}{l}\text { VOCs, SVOCs, TPH (Diesel/Oil), RCRA } \\
\text { Metals, PCBs, Pesticides, Gamma, Sr-90 }\end{array}$ \\
\hline VWDFJ020 & GP8 & $0-1$ & Soil & Environmental Sample & $\begin{array}{l}\text { VOCs, SVOCs, TPH (Diesel/Oil), RCRA } \\
\text { Metals, PCBs, Pesticides, Gamma, Sr-90 }\end{array}$ \\
\hline VWDFJ021 & GP8 & $3-5$ & Soil & Environmental Sample & $\begin{array}{l}\text { VOCs, SVOCs, TPH (Diesel/Oil), RCRA } \\
\text { Metals, PCBs, Pesticides, Gamma, Sr-90 }\end{array}$ \\
\hline VWDFJ022 & GP9 & $0-1$ & Soil & Environmental Sample & $\begin{array}{l}\text { VOCs, SVOCs, TPH (Diesel/Oil), RCRA } \\
\text { Metals, PCBs, Pesticides, Gamma, Sr-90 }\end{array}$ \\
\hline VWDFJ023 & GP9 & $3-5$ & Soil & Environmental Sample & $\begin{array}{l}\text { VOCs, SVOCs, TPH (Diesel/Oil), RCRA } \\
\text { Metals, PCBs, Pesticides, Gamma, Sr-90 }\end{array}$ \\
\hline VWDFJ024 & GP5 & $5-7$ & Soil & Environmental Sample & $\begin{array}{l}\text { VOCs, SVOCs, TPH (Diesel/Oil), RCRA } \\
\text { Metals, PCBs, Pesticides, Gamma, Sr-90 }\end{array}$ \\
\hline VWDFJ025 & $\mathrm{BKH} 1$ & $0-1^{*}$ & Soil & $\begin{array}{l}\text { Environmental Sample } \\
\text { MS/MSD }\end{array}$ & $\begin{array}{l}\text { VOCs, SVOCs, TPH (Diesel/Oil), RCRA } \\
\text { Metals, PCBs, Pesticides, Gamma, Sr-90 }\end{array}$ \\
\hline VWDFJ026 & NA & NA & Water & Source Blank & $\begin{array}{l}\text { VOCs, SVOCs, TPH (Diesel/Oil), RCRA } \\
\text { Metals, PCBs, Pesticides, Gamma, Sr-90 }\end{array}$ \\
\hline VWDFJ027 & NA & NA & Water & Equipment Blank & $\begin{array}{l}\text { VOCs, SVOCs, TPH (Diesel/Oil), RCRA } \\
\text { Metals, PCBs, Pesticides, Gamma, Sr-90 }\end{array}$ \\
\hline VWDFJ028 & NA & NA & Water & Field Blank & $\begin{array}{l}\text { VOCs, SVOCs, TPH (Diesel/Oil), RCRA } \\
\text { Metals, PCBs, Pesticides, Gamma, Sr-90 }\end{array}$ \\
\hline VWDFJ030 & $\mathrm{BKH} 1$ & $1-2^{*}$ & Soil & Environmental Sample & $\begin{array}{l}\text { VOCs, SVOCs, TPH (Diesel/Oil), RCRA } \\
\text { Metals, PCBs, Pesticides, Gamma, Sr-90 }\end{array}$ \\
\hline VWDFJ031 & GP6 & $5-7$ & Soil & Environmental Sample & $\begin{array}{l}\text { VOCs, SVOCs, TPH (Diesel/Oil), RCRA } \\
\text { Metals, PCBs, Pesticides, Gamma, Sr-90 }\end{array}$ \\
\hline VWDFJ032 & GP11 & $0-1$ & Soil & Environmental Sample & $\begin{array}{l}\text { VOCs, SVOCs, TPH (Diesel/Oil), RCRA } \\
\text { Metals, PCBs, Pesticides, Gamma, Sr-90 }\end{array}$ \\
\hline VWDFJ033 & NA & NA & Water & Trip Blank & VOCs \\
\hline
\end{tabular}


Table A.3-1

Samples Collected During the CAU 240 Area 25 Vehicle Washdown Corrective Action Investigation

(Page 4 of 6)

\begin{tabular}{|c|c|c|c|c|c|}
\hline $\begin{array}{l}\text { Sample } \\
\text { Number }\end{array}$ & $\begin{array}{l}\text { Sample } \\
\text { Location }\end{array}$ & $\begin{array}{l}\text { Depth } \\
\text { (ft bgs) }\end{array}$ & $\begin{array}{l}\text { Sample } \\
\text { Matrix }\end{array}$ & $\begin{array}{l}\text { Quality Control } \\
\text { Comments }\end{array}$ & Parameters Analyzed \\
\hline VWDFJ034 & $\mathrm{NA}$ & NA & Water & Trip Blank & VOCs \\
\hline VWDFJ035 & NA & NA & Water & Trip Blank & VOCs \\
\hline VWDFJ036 & NA & NA & Water & Trip Blank & VOCs \\
\hline VWDFJ037 & NA & NA & Water & Trip Blank & VOCs \\
\hline VWDFJ038 & NA & NA & Water & Trip Blank & VOCs \\
\hline VWDFJ039 & NA & NA & Water & Trip Blank & VOCs \\
\hline VWDFJ040 & NA & NA & Water & Field Blank & $\begin{array}{l}\text { VOCs, SVOCs, TPH (Diesel/Oil), RCRA } \\
\text { Metals, PCBs, Pesticides, Gamma, Sr-90 }\end{array}$ \\
\hline VWDFJ041 & NA & NA & Water & Equipment Blank & $\begin{array}{l}\text { VOCs, SVOCs, TPH (Diesel/Oil), RCRA } \\
\text { Metals, PCBs, Pesticides, Gamma, Sr-90 }\end{array}$ \\
\hline VWDFJ042 & NA & NA & Water & Trip Blank & VOCs \\
\hline VWDFJ042A & $\mathrm{N} / \mathrm{A}$ & $\mathrm{N} / \mathrm{A}$ & Water & Trip Blank & VOCs \\
\hline VWDFJ043 & NA & NA & Water & Trip Blank & VOCs \\
\hline VWDFJ044 & NA & NA & Water & Trip Blank & VOCs \\
\hline VWDFJ045 & NA & NA & Water & Equipment Blank & $\begin{array}{l}\text { VOCs, SVOCs, TPH (Diesel/Oil), RCRA } \\
\text { Metals, PCBs, Pesticides, Gamma, Sr-90 }\end{array}$ \\
\hline VWDFJ047 & $\mathrm{BKH3}$ & $0-1^{*}$ & Soil & Environmental Sample & $\begin{array}{l}\text { VOCs, SVOCs, TPH (Diesel/Oil), RCRA } \\
\text { Metals, PCBs, Pesticides, Gamma, Sr-90 }\end{array}$ \\
\hline VWDFJ048 & GP10 & $0-1$ & Soil & Environmental Sample & $\begin{array}{l}\text { VOCs, SVOCs, TPH (Diesel/Oil), RCRA } \\
\text { Metals, PCBs, Pesticides, Gamma, Sr-90 }\end{array}$ \\
\hline VWDFJ050 & $\mathrm{BKH} 3$ & $1-2^{*}$ & Soil & Environmental Sample & $\begin{array}{l}\text { VOCs, SVOCs, TPH (Diesel/Oil), RCRA } \\
\text { Metals, PCBs, Pesticides, Gamma, Sr-90 }\end{array}$ \\
\hline VWDFJ051 & GP12 & $0-1$ & Soil & Environmental Sample & $\begin{array}{l}\text { VOCs, SVOCs, TPH (Diesel/Oil), RCRA } \\
\text { Metals, PCBs, Pesticides, Gamma, Sr-90 }\end{array}$ \\
\hline VWDFJ053 & $\mathrm{BKH} 2$ & $0-1^{*}$ & Soil & $\begin{array}{l}\text { Environmental Sample } \\
\text { MS/MSD }\end{array}$ & $\begin{array}{l}\text { VOCs, SVOCs, TPH (Diesel/Oil), RCRA } \\
\text { Metals, PCBs, Pesticides, Gamma, Sr-90 }\end{array}$ \\
\hline VWDFJ054 & $\mathrm{BKH} 2$ & $1-2^{*}$ & Soil & Environmental Sample & $\begin{array}{l}\text { VOCs, SVOCs, TPH (Diesel/Oil), RCRA } \\
\text { Metals, PCBs, Pesticides, Gamma, Sr-90 }\end{array}$ \\
\hline VWDFJ056 & NA & NA & Water & Trip Blank & VOCs \\
\hline VWDFJ060 & NA & NA & Water & Trip Blank & VOCs \\
\hline VWDFJ061 & $\mathrm{BKH} 3$ & $0-1^{*}$ & Soil & $\begin{array}{l}\text { Field Duplicate of } \\
\text { VWDFJ047 }\end{array}$ & $\begin{array}{l}\text { VOCs, SVOCs, TPH (Diesel/Oil), RCRA } \\
\text { Metals, PCBs, Pesticides, Gamma, Sr-90 }\end{array}$ \\
\hline VWDFJ062 & NA & NA & Water & Source Blank & $\begin{array}{l}\text { VOCs, SVOCs, TPH (Diesel/Oil), RCRA } \\
\text { Metals, PCBs, Pesticides, Gamma, Sr-90 }\end{array}$ \\
\hline \multicolumn{6}{|c|}{ CAS 25-07-03 (RADSAFE Pad) } \\
\hline VWDRP001 & BKG1 & $0-1$ & Soil & Background Sample & RCRA Metals, Gamma, Pu, U, Sr-90 \\
\hline VWDRP002 & BKG1 & $3-5$ & Soil & Background Sample & RCRA Metals, Gamma, Pu, U, Sr-90 \\
\hline VWDRP003 & BKG2 & $0-1$ & Soil & Background Sample & RCRA Metals, Gamma, Pu, U, Sr-90 \\
\hline
\end{tabular}


Table A.3-1

\section{Samples Collected During the CAU 240 Area 25 Vehicle Washdown Corrective Action Investigation}

(Page 5 of 6 )

\begin{tabular}{|c|c|c|c|c|c|}
\hline $\begin{array}{l}\text { Sample } \\
\text { Number }\end{array}$ & $\begin{array}{l}\text { Sample } \\
\text { Location }\end{array}$ & $\begin{array}{l}\text { Depth } \\
\text { (ft bgs) }\end{array}$ & $\begin{array}{l}\text { Sample } \\
\text { Matrix }\end{array}$ & $\begin{array}{l}\text { Quality Control } \\
\text { Comments }\end{array}$ & Parameters Analyzed \\
\hline VWDRP004 & BKG2 & $3-5$ & Soil & Background Sample & RCRA Metals, Gamma, Pu, U, Sr-90 \\
\hline VWDRP005 & GP1 & $0-1$ & Soil & Environmental Sample & $\begin{array}{c}\text { VOCs, SVOCs, TPH (Diesel/Oil), RCRA } \\
\text { Metals, PCBs, Pesticides, Gamma }\end{array}$ \\
\hline VWDRP006 & GP1 & $3-5$ & Soil & $\begin{array}{l}\text { Environmental Sample } \\
\text { Chem. MS/MSD }\end{array}$ & $\begin{array}{l}\text { VOCs, SVOCs, TPH (Diesel/Oil), RCRA } \\
\text { Metals, PCBs, Pesticides, Gamma }\end{array}$ \\
\hline VWDRP007 & GP2 & $0-1$ & Soil & $\begin{array}{l}\text { Environmental Sample } \\
\text { Rad. MS/MSD }\end{array}$ & $\begin{array}{c}\text { VOCs, SVOCs, TPH (Diesel/Oil), RCRA } \\
\text { Metals, PCBs, Pesticides, Gamma }\end{array}$ \\
\hline VWDRP008 & GP2 & $3-5$ & Soil & Environmental Sample & $\begin{array}{l}\text { VOCs, SVOCs, TPH (Diesel/Oil), RCRA } \\
\text { Metals, PCBs, Pesticides, Gamma }\end{array}$ \\
\hline VWDRP009 & GP3 & $0-1$ & Soil & Environmental Sample & $\begin{array}{l}\text { VOCs, SVOCs, TPH (Diesel/Oil), RCRA } \\
\text { Metals, PCBs, Pesticides, Gamma }\end{array}$ \\
\hline VWDRP010 & GP3 & $3-5$ & Soil & Environmental Sample & $\begin{array}{l}\text { VOCs, SVOCs, TPH (Diesel/Oil), RCRA } \\
\text { Metals, PCBs, Pesticides, Gamma }\end{array}$ \\
\hline VWDRP011 & GP4 & $0-1$ & Soil & Environmental Sample & $\begin{array}{c}\text { VOCs, SVOCs, TPH (Diesel/Oil), RCRA } \\
\text { Metals, PCBs, Pesticides, Gamma }\end{array}$ \\
\hline VWDRPX11 & GP4 & $0-1$ & Soil & $\begin{array}{l}\text { Field Duplicate of } \\
\text { VWDRP011 }\end{array}$ & $\begin{array}{l}\text { VOCs, SVOCs, TPH (Diesel/Oil), RCRA } \\
\text { Metals, PCBs, Pesticides, Gamma }\end{array}$ \\
\hline VWDRP012 & GP4 & $3-5$ & Soil & Environmental Sample & $\begin{array}{l}\text { VOCs, SVOCs, TPH Diesel/Oil), RCRA } \\
\text { Metals, PCBs, Pesticides, Gamma }\end{array}$ \\
\hline VWDRP013 & GP5 & $0-1$ & Soil & Environmental Sample & $\begin{array}{c}\text { VOCs, SVOCs, TPH (Diesel/Oil), RCRA } \\
\text { Metals, PCBs, Pesticides, Gamma }\end{array}$ \\
\hline VWDRP014 & GP5 & $3-5$ & Soil & Environmental Sample & $\begin{array}{l}\text { VOCs, SVOCs, TPH (Diesel/Oil), RCRA } \\
\text { Metals, PCBs, Pesticides, Gamma }\end{array}$ \\
\hline VWDRP015 & GP6 & $0-1$ & Soil & $\begin{array}{c}\text { Environmental Sample } \\
\text { MS/MSD }\end{array}$ & $\begin{array}{c}\text { VOCs, SVOCs, TPH (Diesel/Oil), RCRA } \\
\text { Metals, PCBs, Pesticides, Gamma }\end{array}$ \\
\hline VWDRPX16 & NA & NA & Water & Source Blank & $\begin{array}{l}\text { VOCs, SVOCs, TPH (Diesel/Oil), RCRA } \\
\text { Metals, PCBs, Pesticides, Gamma, Sr-90 }\end{array}$ \\
\hline VWDRP017 & NA & NA & Water & Equipment Blank & $\begin{array}{l}\text { VOCs, SVOCs, TPH (Diesel/Oil), RCRA } \\
\text { Metals, PCBs, Pesticides, Gamma, Sr-90 }\end{array}$ \\
\hline VWDRP018 & NA & NA & Water & Field Blank & $\begin{array}{l}\text { VOCs, SVOCs, TPH (Diesel/Oil), RCRA } \\
\text { Metals, PCBs, Pesticides, Gamma, Sr-90 }\end{array}$ \\
\hline VWDRP020 & GP6 & $3-5$ & Soil & Environmental Sample & $\begin{array}{c}\text { VOCs, SVOCs, TPH (Diesel/Oil), RCRA } \\
\text { Metals, PCBs, Pesticides, Gamma }\end{array}$ \\
\hline VWDRP021 & GP7 & $0-1$ & Soil & Environmental Sample & $\begin{array}{c}\text { VOCs, SVOCs, TPH (Diesel/Oil), RCRA } \\
\text { Metals, PCBs, Pesticides, Gamma }\end{array}$ \\
\hline VWDRP022 & GP7 & $3-5$ & Soil & Environmental Sample & $\begin{array}{l}\text { VOCs, SVOCs, TPH (Diesel/Oil), RCRA } \\
\text { Metals, PCBs, Pesticides, Gamma }\end{array}$ \\
\hline VWDRP023 & GP8 & $0-1$ & Soil & Environmental Sample & $\begin{array}{c}\text { VOCs, SVOCs, TPH (Diesel/Oil), RCRA } \\
\text { Metals, PCBs, Pesticides, Gamma }\end{array}$ \\
\hline VWDRP024 & GP8 & $3-5$ & Soil & Environmental Sample & $\begin{array}{c}\text { VOCs, SVOCs, TPH (Diesel/Oil), RCRA } \\
\text { Metals, PCBs, Pesticides, Gamma }\end{array}$ \\
\hline
\end{tabular}


Table A.3-1

\section{Samples Collected During the CAU 240 Area 25 Vehicle Washdown Corrective Action Investigation}

(Page 6 of 6 )

\begin{tabular}{|c|c|c|c|c|c|}
\hline $\begin{array}{c}\text { Sample } \\
\text { Number }\end{array}$ & $\begin{array}{c}\text { Sample } \\
\text { Location }\end{array}$ & $\begin{array}{c}\text { Depth } \\
\text { (ft bgs) }\end{array}$ & $\begin{array}{c}\text { Sample } \\
\text { Matrix }\end{array}$ & $\begin{array}{c}\text { Quality Control } \\
\text { Comments }\end{array}$ & Parameters Analyzed \\
\hline \hline VWDRP025 & GP9 & $0-1$ & Soil & Environmental Sample & $\begin{array}{c}\text { VOCs, SVOCs, TPH (Diesel/Oil), RCRA } \\
\text { Metals, PCBs, Pesticides, Gamma }\end{array}$ \\
\hline VWDRP026 & GP9 & $3-5$ & Soil & Environmental Sample & $\begin{array}{c}\text { VOCs, SVOCs, TPH (Diesel/Oil), RCRA } \\
\text { Metals, PCBs, Pesticides, Gamma }\end{array}$ \\
\hline VWDRP027 & NA & NA & Water & Trip Blank & VOCs \\
\hline VWDRP028 & NA & NA & Water & Trip Blank & VOCs \\
\hline VWDRP029 & NA & NA & Water & Trip Blank & VOCs \\
\hline VWDRP030 & NA & NA & Water & Trip Blank & VOCs \\
\hline VWDRP031 & NA & NA & Water & Trip Blank & VOCs \\
\hline VWDRP032 & NA & NA & Water & Trip Blank & VOCs \\
\hline VWDRP033 & NA & NA & Water & Trip Blank & \\
\hline
\end{tabular}

BKG denotes background sample location

BKH denotes backhoe sample location

GP denotes Geoprobe ${ }^{\circledR}$ sample location

MS/MSD = Matrix spike and matrix spike duplicate

$\mathrm{NA}=$ Not Applicable

VOCs = Volatile organic compounds

$\mathrm{TPH}=$ Total petroleum hydrocarbons

SVOCs = Semivolatile organic compounds

$\mathrm{RCRA}=$ Resource Conservation and Recovery Act

$\mathrm{PCB}=$ Polychlorinated biphenyls

Sr-90 = Strontium-90

Gamma = Gamma spectrometry

$\mathrm{Pu}=$ Isotopic plutonium

$\mathrm{U}=$ Isotopic uranium

${ }^{*}$ Depth represents feet below soil/gravel interface.

The analytical parameters were selected through the application of site process knowledge according to the EPA's Guidance for the Data Quality Objectives Process (EPA, 1994a). Preliminary action levels for off-site laboratory analytical methods were determined during the DQO process and are documented in the CAIP (DOE/NV, 1999; EPA, 1998). Sampling activities were conducted to confirm or disprove assumptions (i.e., models outlined in CAIP) made in the DQO process (DOE/NV, 1999). 
Table A.3-2

Laboratory Analytical Methods Used for Samples Collected at the CAU 240, Area 25 Vehicle Washdown, Nevada Test Site

\begin{tabular}{|c|c|}
\hline Analytical Parameter & Analytical Method \\
\hline Total volatile organic compounds & EPA $8260 B^{a}$ \\
\hline Total petroleum hydrocarbons - diesel/oil & EPA 8015B (modified) ${ }^{a}$ \\
\hline Total semivolatile organic compounds & EPA $8270 C^{a}$ \\
\hline $\begin{array}{l}\text { Total RCRA metals (arsenic, barium, cadmium, chromium, lead, selenium, silver, and } \\
\text { mercury) }\end{array}$ & $\begin{array}{l}\text { EPA } 6010 B / 7470 A^{a} \\
\text { EPA } 6010 B / 7471 A^{a}\end{array}$ \\
\hline Total pesticides & EPA $8081 A^{a}$ \\
\hline Polychlorinated biphenyls & EPA $8082^{a}$ \\
\hline Gamma spectrometry & BN-L-E10.602.PC \\
\hline Strontium-90 & $\begin{array}{l}\text { BN-L-E10610.PL } \\
\text { SOP-PAI-717, } 724^{\mathrm{b}}\end{array}$ \\
\hline Isotopic plutonium & BN-L-E10.601.PL ${ }^{c}$ \\
\hline Isotopic uranium & BN-L-E10.605.PL ${ }^{\mathrm{c}}$ \\
\hline
\end{tabular}

a EPA Test Methods for Evaluating Solid Waste, 3rd Edition, Parts 1-4, SW-846 (EPA, 1996)

b Paragon Analytics Incorporated Standard Operation Procedure Manual (PAI, 1996 and 1999)

${ }^{\mathrm{C} B e c h t e l}$ Nevada Analytical Services Laboratory Procedure Manual I (BN ASL, 1999)

\section{A.3.1 Total Volatile Organic Compound Analytical Results}

The total VOC analytical results detected above minimum reporting limits established in the CAIP (DOE/NV, 1999), along with the associated preliminary action levels, are presented in Table A.3-3. None of these results exceed the PALs (DOE/NV, 1999; EPA, 1998).

Approximately half of the results for acrolein were rejected for samples collected from the Propellant Pad and the RADSAFE Pad. Acrolein is most commonly used as an herbicide in irrigation canals (EPA, 1989). It is also used as a pesticide. Acrolein is highly volatile and is not persistent in the environment. It does not concentrate in sediments (EC, 1999). This is an acceptable data gap because acrolein is not expected at these CASs and it was not detected in other usable results for acrolein. 
Table A.3-3

Soil Sample Results for Total Volatile Organic Compounds Detected Above Minimum Reporting Limits, Area 25 Vehicle Washdown, Nevada Test Site (Page 1 of 2)

\begin{tabular}{|c|c|c|c|c|c|c|}
\hline \multirow{2}{*}{$\begin{array}{l}\text { Sample } \\
\text { Location }\end{array}$} & \multirow[b]{2}{*}{ Sample No. } & \multirow{2}{*}{$\begin{array}{c}\text { Start Depth } \\
\text { (ft) }\end{array}$} & \multirow{2}{*}{$\begin{array}{l}\text { End Depth } \\
\text { (ft) }\end{array}$} & \multicolumn{3}{|c|}{ Contaminant of Potential Concern $(\mu \mathrm{g} / \mathbf{k g})$} \\
\hline & & & & 2-Butanone & Acetone & $\begin{array}{c}\text { Methylene } \\
\text { Chloride }\end{array}$ \\
\hline \multicolumn{4}{|c|}{ Preliminary Action Levels ${ }^{\mathrm{a}}$} & $27,000,000$ & $6,100,000$ & 20,000 \\
\hline \multicolumn{7}{|c|}{ CAS 25-07-01 Propellant Pad } \\
\hline \multirow{2}{*}{ GP1 } & VWDPP008 & 0.0 & 1 & -- & $15(\mathrm{~J})$ & $\overline{--}$ \\
\hline & VWDPP009 & 3.0 & 5.0 & $\overline{--}$ & $16(\mathrm{~J})$ & -- \\
\hline \multirow{2}{*}{ GP2 } & VWDPP010 & 0.0 & 1.0 & -- & $15(\mathrm{~J})$ & $\begin{array}{l}- \\
-\end{array}$ \\
\hline & VWDPP011 & 3.0 & 5.0 & -- & $6.9(\mathrm{~J})$ & -- \\
\hline \multirow{2}{*}{ GP3 } & VWDPP012 & 0.0 & 1.0 & -- & $13(\mathrm{~J})$ & -- \\
\hline & VWDPP013 & 3.0 & 5.0 & -- & $8.6(\mathrm{~J})$ & -- \\
\hline \multirow{2}{*}{ GP4 } & VWDPP014 & 0.0 & 1.0 & -- & $10(\mathrm{~J})$ & -- \\
\hline & VWDPP016 & 3.0 & 5.0 & $\overline{--}$ & $8(\mathrm{~J})$ & -- \\
\hline GP5 & VWDPP018 & 3.0 & 5.0 & $\overline{--}$ & $7.5(\mathrm{~J})$ & -- \\
\hline GP4 & VWDPP025 & 5.0 & 7.0 & -- & $12(\mathrm{~J})$ & -- \\
\hline GP6 & VWDPP028 & 0.0 & 1.0 & -- & $15(\mathrm{~J})$ & -- \\
\hline GP7 & VWDPP030 & 0.0 & 1.0 & -- & $6.4(\mathrm{~J})$ & -- \\
\hline GP8 & VWDPP032 & 0.0 & 1.0 & -- & $8.2(\mathrm{~J})$ & -- \\
\hline \multicolumn{7}{|c|}{ CAS 25-07-02 F and J Roads Pad } \\
\hline \multirow{2}{*}{ GP1 } & VWDFJ005 & 0.0 & 1.0 & $\overline{--}$ & 23 & -- \\
\hline & VWDFJ006 & 3.0 & 5.0 & -- & $7.8(\mathrm{~J})$ & -- \\
\hline \multirow{2}{*}{ GP2 } & VWDFJ007 & 0.0 & 1.0 & -- & 22 & -- \\
\hline & VWDFJ008 & 3.0 & 5.0 & -- & $8.5(\mathrm{~J})$ & -- \\
\hline \multirow{3}{*}{ GP3 } & VWDFJ009 & 0.0 & 1.0 & -- & $15(\mathrm{~J})$ & -- \\
\hline & VWDFJ010 & 3.0 & 5.0 & -- & $13(\mathrm{~J})$ & -- \\
\hline & VWDFJX10 & 3.0 & 5.0 & $\overline{--}$ & $14(\mathrm{~J})$ & -- \\
\hline \multirow{2}{*}{ GP4 } & VWDFJ011 & 0.0 & 1.0 & $\overline{--}$ & $13(\mathrm{~J})$ & -- \\
\hline & VWDFJ012 & 3.0 & 5.0 & -- & $19(\mathrm{~J})$ & -- \\
\hline \multirow{2}{*}{ GP5 } & VWDFJ013 & 0.0 & 1.0 & -- & 26 & -- \\
\hline & VWDFJ014 & 3.0 & 5.0 & -- & $8.5(\mathrm{~J})$ & -- \\
\hline GP9 & VWDFJ022 & 0.0 & 1.0 & $5.8(\mathrm{~J})$ & $\overline{--}$ & -- \\
\hline $\mathrm{BKH} 1$ & VWDFJ030 & 1.0 & 2.0 & $5.4(\mathrm{~J})$ & -- & $5.5(\mathrm{~J})$ \\
\hline GP6 & VWDFJ031 & 5.0 & 7.0 & $6.5(\mathrm{~J})$ & -- & $6(\mathrm{~J})$ \\
\hline $\mathrm{BKH} 3$ & VWDFJ047 & 0.0 & 1.0 & $5.6(\mathrm{~J})$ & $8.7(\mathrm{~J})$ & -- \\
\hline
\end{tabular}


Table A.3-3

Soil Sample Results for Total Volatile Organic Compounds Detected Above Minimum Reporting Limits, Area 25 Vehicle Washdown, Nevada Test Site (Page 2 of 2 )

\begin{tabular}{|c|c|c|c|c|c|c|}
\hline \multirow{2}{*}{$\begin{array}{l}\text { Sample } \\
\text { Location }\end{array}$} & \multirow[b]{2}{*}{ Sample No. } & \multirow{2}{*}{$\begin{array}{c}\text { Start Depth } \\
\text { (ft) }\end{array}$} & \multirow{2}{*}{$\begin{array}{c}\text { End Depth } \\
\text { (ft) }\end{array}$} & \multicolumn{3}{|c|}{ Contaminant of Potential Concern $(\mu \mathrm{g} / \mathbf{k g})$} \\
\hline & & & & 2-Butanone & Acetone & $\begin{array}{c}\text { Methylene } \\
\text { Chloride }\end{array}$ \\
\hline \multicolumn{4}{|c|}{ Preliminary Action Levels ${ }^{a}$} & $27,000,000$ & $6,100,000$ & 20,000 \\
\hline \multicolumn{7}{|c|}{ CAS 25-07-05 RADSAFE Pad } \\
\hline \multirow{2}{*}{ GP1 } & VWDRP005 & 0.0 & 1.0 & -- & $6.6(\mathrm{~J})$ & -- \\
\hline & VWDRP006 & 3.0 & 5.0 & -- & $5(\mathrm{~J})$ & -- \\
\hline GP2 & VWDRP008 & 3.0 & 5.0 & -- & $8.4(\mathrm{~J})$ & -- \\
\hline \multirow{2}{*}{ GP3 } & VWDRP009 & 0.0 & 1.0 & -- & 15 (J) & -- \\
\hline & VWDRP010 & 3.0 & 5.0 & -- & $9.4(\mathrm{~J})$ & -- \\
\hline \multirow{3}{*}{ GP4 } & VWDRP011 & 0.0 & 1.0 & -- & $25(\mathrm{~J})$ & -- \\
\hline & VWDRPX11 & 0.0 & 1.0 & -- & $36(\mathrm{~J})$ & -- \\
\hline & VWDRP012 & 3.0 & 5.0 & -- & 17 (J) & -- \\
\hline \multirow{2}{*}{ GP5 } & VWDRP013 & 0.0 & 1.0 & -- & $20(\mathrm{~J})$ & -- \\
\hline & VWDRP014 & 3.0 & 5.0 & -- & $15(\mathrm{~J})$ & -- \\
\hline GP6 & VWDRP015 & 0.0 & 1.0 & -- & $33(\mathrm{~J})$ & -- \\
\hline GP7 & VWDRP021 & 0.0 & 1.0 & -- & $30(\mathrm{~J})$ & -- \\
\hline \multirow{2}{*}{ GP8 } & VWDRP023 & 0.0 & 1.0 & -- & $21(\mathrm{~J})$ & -- \\
\hline & VWDRP024 & 3.0 & 5.0 & -- & $13(\mathrm{~J})$ & -- \\
\hline \multirow{2}{*}{ GP9 } & VWDRP025 & 0.0 & 1.0 & -- & $27(\mathrm{~J})$ & -- \\
\hline & VWDRP026 & 3.0 & 5.0 & -- & $11(\mathrm{~J})$ & -- \\
\hline
\end{tabular}

aEPA Region 9 Industrial PRGs (EPA, 1998)

$\mathrm{J}=$ Estimated value

-- = Not detected above minimum reporting limit

$\mu \mathrm{g} / \mathrm{kg}=$ Micrograms per kilogram

\section{A.3.2 Total Semivolatile Organic Compound Analytical Results}

Sample VWDPP016 had a bis(2-ethylhexyl)phthalate concentration of 240 micrograms per kilogram $(\mu \mathrm{g} / \mathrm{kg}$ ) which is well below the $210,000 \mu \mathrm{g} / \mathrm{kg}$ PAL (DOE/NV, 1999; EPA, 1998). This constituent is a common laboratory contaminant. All other SVOC results were reported as nondetects.

Therefore, SVOCs were not detected at concentrations exceeding PALs. 


\section{A.3.3 Total Petroleum Hydrocarbon Analytical Results}

The TPH-diesel detected in soil above the minimum reporting limits (DOE/NV, 1999) are presented in Table A.3-4. Total petroleum hydrocarbons were detected in the diesel range above the NDEP regulatory action level of $100 \mathrm{mg} / \mathrm{kg}$ for TPH (NAC, 1997) only at the F and J Roads Pad. The TPH-diesel concentrations ranged from $29 \mathrm{mg} / \mathrm{kg}$ to $1,500 \mathrm{mg} / \mathrm{kg}$ at the F and J Roads Pad. The highest concentrations were found around the perimeter of the concrete decontamination pad (Figure A.2-3).

\section{A.3.4 Total RCRA Metals Results}

The total RCRA metals detected above the minimum reporting limits (DOE/NV, 1999) are presented in Table A.3-5. The total RCRA metal results were all below the PALs except for arsenic (DOE/NV, 1999; EPA, 1998).

Arsenic was detected above the PAL of $3.0 \mathrm{mg} / \mathrm{kg}$ in most of the samples analyzed. The arsenic concentrations for the samples analyzed ranged from $1.9 \mathrm{mg} / \mathrm{kg}$ to $10.2 \mathrm{mg} / \mathrm{kg}$. The $10.2 \mathrm{mg} / \mathrm{kg}$ concentration for sample VWDFJ023 is nearly twice that of the next highest concentration of $5.3 \mathrm{mg} / \mathrm{kg}$ in sample VWDRP022. Both of these samples were collected from 3 to $5 \mathrm{ft}$ bgs. Samples collected from 0 to $1 \mathrm{ft}$ bgs at the same locations contained lower concentrations of arsenic.

Although analysis of most samples, including the site-specific background samples, reveal arsenic concentrations near or above $3.0 \mathrm{mg} / \mathrm{kg}$, this PAL is lower than the 7 to $8 \mathrm{ppm}(\mathrm{mg} / \mathrm{kg}) \mathrm{mean}$ concentration of arsenic in silt from the Nellis Air Force Range (NBMG, 1998; Moore, 1999). Several arsenic concentrations presented in Table A.3-5 exceed the PAL but are considered representative of ambient conditions at the sites.

\section{A.3.5 Total Pesticides Results}

The total pesticides results detected in soil above the minimum reporting limits (DOE/NV, 1999) are presented in Table A.3-6. One sample from the Propellant Pad site and five samples from the RADSAFE site, indicated that pesticides were present above the minimum reporting limits; however, these results were well below the PALs (DOE/NV, 1999; EPA, 1998). The alpha- and gamma-chlordane isomer concentrations were reported instead of the chlordane concentration. To 
Table A.3-4

Soil Sample Results for Total Petroleum Hydrocarbons Detected Above Minimum Reporting Limits, Area 25 Vehicle Washdown, Nevada Test Site

\begin{tabular}{|c|c|c|c|c|}
\hline \multirow{2}{*}{$\begin{array}{l}\text { Sample } \\
\text { Location }\end{array}$} & \multirow{2}{*}{ Sample No. } & \multirow{2}{*}{ Start Depth (ft) } & \multirow{2}{*}{ End Depth (ft) } & \multirow{2}{*}{$\begin{array}{c}\text { Contaminant of Potential Concern }(\mathrm{mg} / \mathrm{kg}) \\
\text { DIESEL-RANGE ORGANICS }\end{array}$} \\
\hline & & & & \\
\hline \multicolumn{4}{|c|}{ Preliminary Action Level } & 100 \\
\hline \multicolumn{5}{|c|}{ CAS 25-07-02 F and J Roads Pad } \\
\hline GP3 & VWDFJ009 & 0.0 & 1.0 & 890 \\
\hline GP4 & VWDFJ011 & 0.0 & 1.0 & 1,200 \\
\hline GP5 & VWDFJ013 & 0.0 & 1.0 & 1,500 \\
\hline GP6 & VWDFJ015 & 0.0 & 1.0 & 1,200 \\
\hline \multirow{3}{*}{ GP7 } & VWDFJ017 & 0.0 & 1.0 & 910 \\
\hline & VWDFJ018 & 3.0 & 5.0 & 31 \\
\hline & VWDFJ019 & 3.0 & 5.0 & 29 \\
\hline GP8 & VWDFJ020 & 0.0 & 1.0 & 1,200 \\
\hline \multirow{2}{*}{ GP9 } & VWDFJ022 & 0.0 & 1.0 & 31 \\
\hline & VWDFJ023 & 3.0 & 5.0 & 380 \\
\hline GP11 & VWDFJ032 & 0.0 & 1.0 & 36 \\
\hline GP10 & VWDFJ048 & 0.0 & 1.0 & 75 \\
\hline GP12 & VWDFJ051 & 0.0 & 1.0 & 91 \\
\hline \multicolumn{5}{|c|}{ CAS 25-07-03 RADSAFE Pad } \\
\hline GP2 & VWDRP007 & 0.0 & 1.0 & 26 \\
\hline
\end{tabular}

Shading indicates analytical result exceeds the $100 \mathrm{mg} / \mathrm{kg}$ NDEP established action level.

compare these concentrations to the PAL, the alpha- and gamma-chlordane isomer concentrations were summed and presented in Table A.3-6 as chlordane.

\section{A.3.6 PCB Results}

Sample VWDRP007 had an aroclor- 1260 concentration of $36 \mu \mathrm{g} / \mathrm{kg}$. This concentration is less than the 1,300 $\mu \mathrm{g} / \mathrm{kg}$ PAL (DOE/NV, 1999; EPA 1998) for PCBs. All other PCB results were reported as nondetects or at concentrations below their minimum reporting limits (DOE/NV, 1999). Therefore, PCBs were not detected in soil at concentrations exceeding PALs. 
Table A.3-5

Summary of Total RCRA Metals Results Detected Above Minimum Reporting Limits, Area 25 Vehicle Washdown, Nevada Test Site (Page 1 of 2)

\begin{tabular}{|c|c|c|c|c|c|c|c|c|c|}
\hline \multirow{2}{*}{$\begin{array}{c}\text { Sample } \\
\text { Location }\end{array}$} & \multirow{2}{*}{ Sample No. } & \multirow{2}{*}{$\begin{array}{c}\text { Start } \\
\text { Depth } \\
\text { (ft) }\end{array}$} & \multirow{2}{*}{$\begin{array}{c}\text { End } \\
\text { Depth } \\
\text { (ft) }\end{array}$} & \multicolumn{6}{|c|}{ Contaminant of Potential Concern $(\mathrm{mg} / \mathrm{kg})$} \\
\hline & & & & Arsenic & Barium & Chromium & Lead & Mercury & Selenium \\
\hline \multicolumn{4}{|c|}{ Preliminary Action Levels ${ }^{a}$} & 3.0 & 100,000 & 64.0 & 1,000 & 560 & 9,400 \\
\hline \multicolumn{10}{|c|}{ CAS 25-07-01 Propellant Pad } \\
\hline \multirow{2}{*}{ BKG1 } & VWDPP001 & 0.0 & 1.0 & $2.8(\mathrm{~J})$ & $105(\mathrm{~J})$ & $4.5(\mathrm{~J})$ & $6.1(\mathrm{~J})$ & -- & $\overline{--}$ \\
\hline & VWDPP002 & 3.0 & 5.0 & $3.9(\mathrm{~J})$ & $55.9(\mathrm{~J})$ & $2.8(\mathrm{~J})$ & $4.4(\mathrm{~J})$ & -- & -- \\
\hline \multirow{2}{*}{ BKG2 } & VWDPP003 & 0.0 & 1.0 & $2.2(\mathrm{~J})$ & $99.9(\mathrm{~J})$ & $3.4(\mathrm{~J})$ & $5.3(\mathrm{~J})$ & & -- \\
\hline & VWDPP004 & 3.0 & 5.0 & $3.8(\mathrm{~J})$ & $131(\mathrm{~J})$ & $3(\mathrm{~J})$ & $5.4(\mathrm{~J})$ & -- & -- \\
\hline \multicolumn{10}{|c|}{ CAS 25-07-02 F and J Roads Pad } \\
\hline \multirow{2}{*}{ BKG1 } & VWDFJ001 & 0.0 & 1.0 & $2.9(\mathrm{~J})$ & 82.9 & $5.2(\mathrm{~J})$ & 6.1 & -- & -- \\
\hline & VWDFJ002 & 3.0 & 5.0 & $2.8(\mathrm{~J})$ & 103 & $2.9(\mathrm{~J})$ & 5.8 & -- & -- \\
\hline \multirow{2}{*}{ BKG2 } & VWDFJ003 & 0.0 & 1.0 & $2.7(\mathrm{~J})$ & 105 & $4.2(\mathrm{~J})$ & 6.5 & -- & -- \\
\hline & VWDFJ004 & 3.0 & 4.0 & $2.2(\mathrm{~J})$ & 110 & $1.8(\mathrm{~J})$ & 4.4 & -- & -- \\
\hline \multirow{2}{*}{ GP1 } & VWDFJ005 & 0.0 & 1.0 & $3.5(\mathrm{~J})$ & 100 & $4.9(\mathrm{~J})$ & 8 & -- & -- \\
\hline & VWDFJ006 & 3.0 & 5.0 & $3.1(\mathrm{~J})$ & 81.8 & $3.1(\mathrm{~J})$ & 6.3 & -- & -- \\
\hline \multirow{2}{*}{ GP2 } & VWDFJ007 & 0.0 & 1.0 & $3.7(\mathrm{~J})$ & 116 & $5.5(\mathrm{~J})$ & 9.3 & -- & -- \\
\hline & VWDFJ008 & 3.0 & 5.0 & $3.5(\mathrm{~J})$ & 88.4 & $2.2(\mathrm{~J})$ & 5 & 0.14 & -- \\
\hline \multirow{3}{*}{ GP3 } & VWDFJ009 & 0.0 & 1.0 & $3.5(\mathrm{~J})$ & 105 & $5(\mathrm{~J})$ & 10.2 & -- & -- \\
\hline & VWDFJ010 & 3.0 & 5.0 & $2.5(\mathrm{~J})$ & 76.9 & $1.9(\mathrm{~J})$ & 7 & -- & -- \\
\hline & VWDFJX10 & 3.0 & 5.0 & $2.7(\mathrm{~J})$ & 98.6 & $1.9(\mathrm{~J})$ & 4.1 & -- & -- \\
\hline \multirow{2}{*}{ GP4 } & VWDFJ011 & 0.0 & 1.0 & $3.2(\mathrm{~J})$ & 152 & $4.6(\mathrm{~J})$ & 9.4 & -- & -- \\
\hline & VWDFJ012 & 3.0 & 5.0 & $2.5(\mathrm{~J})$ & 99.6 & $1.7(\mathrm{~J})$ & 4.9 & -- & -- \\
\hline \multirow{2}{*}{ GP5 } & VWDFJ013 & 0.0 & 1.0 & $4.9(\mathrm{~J})$ & 114 & $4.9(\mathrm{~J})$ & 10.4 & -- & -- \\
\hline & VWDFJ014 & 3.0 & 5.0 & $2.3(\mathrm{~J})$ & 78.6 & $1.5(\mathrm{~J})$ & 4.8 & -- & -- \\
\hline \multirow{2}{*}{ GP6 } & VWDFJ015 & 0.0 & 1.0 & $4.1(\mathrm{~J})$ & $132(\mathrm{~J})$ & $8.7(\mathrm{~J})$ & $9.3(\mathrm{~J})$ & -- & -- \\
\hline & VWDFJ016 & 3.0 & 5.0 & $2.4(\mathrm{~J})$ & $73.3(\mathrm{~J})$ & $1.9(\mathrm{~J})$ & $6.6(\mathrm{~J})$ & -- & -- \\
\hline \multirow{3}{*}{ GP7 } & VWDFJ017 & 0.0 & 1.0 & $3.6(\mathrm{~J})$ & $223(\mathrm{~J})$ & $4.5(\mathrm{~J})$ & $8.9(\mathrm{~J})$ & -- & -- \\
\hline & VWDFJ018 & 3.0 & 5.0 & $2.4(\mathrm{~J})$ & 75.8 (J) & $2.3(\mathrm{~J})$ & $4.3(\mathrm{~J})$ & -- & -- \\
\hline & VWDFJ019 & 3.0 & 5.0 & $2.3(\mathrm{~J})$ & $49.8(\mathrm{~J})$ & $1.7(\mathrm{~J})$ & $4.2(\mathrm{~J})$ & -- & $\overline{--}$ \\
\hline \multirow{2}{*}{ GP8 } & VWDFJ020 & 0.0 & 1.0 & $3.9(\mathrm{~J})$ & $107(\mathrm{~J})$ & $4.3(\mathrm{~J})$ & $6.6(\mathrm{~J})$ & -- & -- \\
\hline & VWDFJ021 & 3.0 & 5.0 & $2.7(\mathrm{~J})$ & $53.1(\mathrm{~J})$ & $1.6(\mathrm{~J})$ & $3.8(\mathrm{~J})$ & -- & -- \\
\hline \multirow{2}{*}{ GP9 } & VWDFJ022 & 0.0 & 1.0 & $3.2(\mathrm{~J})$ & $103(\mathrm{~J})$ & $4.4(\mathrm{~J})$ & $8.1(\mathrm{~J})$ & -- & -- \\
\hline & VWDFJ023 & 3.0 & 5.0 & $10.2(\mathrm{~J})$ & $172(\mathrm{~J})$ & $6.2(\mathrm{~J})$ & $14.5(\mathrm{~J})$ & -- & $2.8(\mathrm{~J})$ \\
\hline GP5 & VWDFJ024 & 5.0 & 7.0 & $2.2(\mathrm{~J})$ & $89.6(\mathrm{~J})$ & $1.8(\mathrm{~J})$ & $4.2(\mathrm{~J})$ & -- & -- \\
\hline \multirow{2}{*}{$\mathrm{BKH} 1$} & VWDFJ025 & 0.0 & 1.0 & $1.9(\mathrm{~J})$ & $63.8(\mathrm{~J})$ & $1.5(\mathrm{~J})$ & $3.2(\mathrm{~J})$ & -- & -- \\
\hline & VWDFJ030 & 1.0 & 2.0 & $2.1(\mathrm{~J})$ & $66.1(\mathrm{~J})$ & $1.4(\mathrm{~J})$ & $3.4(\mathrm{~J})$ & -- & -- \\
\hline GP6 & VWDFJ031 & 5.0 & 7.0 & $2.3(\mathrm{~J})$ & $105(\mathrm{~J})$ & $2.1(\mathrm{~J})$ & $5.3(\mathrm{~J})$ & -- & -- \\
\hline GP11 & VWDFJ032 & 0.0 & 1.0 & $3.1(\mathrm{~J})$ & $113(\mathrm{~J})$ & $3.6(\mathrm{~J})$ & $8.2(\mathrm{~J})$ & -- & -- \\
\hline GP10 & VWDFJ048 & 0.0 & 1.0 & $3.2(\mathrm{~J})$ & $113(\mathrm{~J})$ & $4.8(\mathrm{~J})$ & $7.6(\mathrm{~J})$ & -- & $\overline{--}$ \\
\hline
\end{tabular}


Table A.3-5

Summary of Total RCRA Metals Results Detected Above Minimum Reporting Limits, Area 25 Vehicle Washdown, Nevada Test Site (Page 2 of 2)

\begin{tabular}{|c|c|c|c|c|c|c|c|c|c|}
\hline \multirow{2}{*}{$\begin{array}{l}\text { Sample } \\
\text { Location }\end{array}$} & \multirow{2}{*}{ Sample No. } & \multirow{2}{*}{$\begin{array}{c}\text { Start } \\
\text { Depth } \\
\text { (ft) }\end{array}$} & \multirow{2}{*}{$\begin{array}{c}\text { End } \\
\text { Depth } \\
\text { (ft) }\end{array}$} & \multicolumn{6}{|c|}{ Contaminant of Potential Concern $(\mathrm{mg} / \mathrm{kg})$} \\
\hline & & & & Arsenic & Barium & Chromium & Lead & Mercury & Selenium \\
\hline \multicolumn{4}{|c|}{ Preliminary Action Levels ${ }^{a}$} & 3.0 & 100,000 & 64.0 & 1,000 & 560 & 9,400 \\
\hline \multicolumn{10}{|c|}{ CAS 25-07-02 F and J Roads Pad } \\
\hline GP12 & VWDFJ051 & 0.0 & 1.0 & $3.2(\mathrm{~J})$ & $99.8(\mathrm{~J})$ & $4.2(\mathrm{~J})$ & $6.3(\mathrm{~J})$ & -- & -- \\
\hline \multirow{2}{*}{$\mathrm{BKH} 2$} & VWDFJ053 & 0.0 & 1.0 & $2.5(\mathrm{~J})$ & $44.1(\mathrm{~J})$ & $1.4(\mathrm{~J})$ & $3.9(\mathrm{~J})$ & -- & -- \\
\hline & VWDFJ054 & 1.0 & 2.0 & $2.6(\mathrm{~J})$ & $104(\mathrm{~J})$ & $2(\mathrm{~J})$ & $5.1(\mathrm{~J})$ & -- & -- \\
\hline \multirow{3}{*}{$\mathrm{BKH} 3$} & VWDFJ047 & 0.0 & 1.0 & $2.7(\mathrm{~J})$ & $94.8(\mathrm{~J})$ & $2(\mathrm{~J})$ & $4.6(\mathrm{~J})$ & -- & -- \\
\hline & VWDFJ050 & 1.0 & 2.0 & $3.8(\mathrm{~J})$ & $76.4(\mathrm{~J})$ & $2(\mathrm{~J})$ & $5.3(\mathrm{~J})$ & -- & -- \\
\hline & VWDFJ061 & 0.0 & 1.0 & $2.7(\mathrm{~J})$ & $89.8(J)$ & $2.5(\mathrm{~J})$ & $5.2(\mathrm{~J})$ & -- & -- \\
\hline \multicolumn{10}{|c|}{ CAS 25-07-03 RADSAFE Pad } \\
\hline \multirow{2}{*}{ BKG1 } & VWDRP001 & 0.0 & 1.0 & $3.4(\mathrm{~J})$ & 97.9 & 5.3 & 7.2 & -- & -- \\
\hline & VWDRP002 & 3.0 & 5.0 & $3.9(\mathrm{~J})$ & 95.9 & 4.2 & 6.3 & $\overline{--}$ & -- \\
\hline \multirow{2}{*}{ BKG2 } & VWDRP003 & 0.0 & 1.0 & $3.3(\mathrm{~J})$ & 116 & 5.4 & 9.7 & -- & -- \\
\hline & VWDRP004 & 3.0 & 5.0 & $3.5(\mathrm{~J})$ & 161 & 4.6 & 6.3 & & -- \\
\hline \multirow{2}{*}{ GP1 } & VWDRP005 & 0.0 & 1.0 & $3.2(\mathrm{~J})$ & 84.2 & 5.5 & 7.3 & -- & -- \\
\hline & VWDRP006 & 3.0 & 5.0 & $4.3(\mathrm{~J})$ & 121 & 7.8 & 7.5 & -- & $\overline{--}$ \\
\hline \multirow{2}{*}{ GP2 } & VWDRP007 & 0.0 & 1.0 & $3.2(\mathrm{~J})$ & $88.6(\mathrm{~J})$ & $4.8(\mathrm{~J})$ & $15.5(\mathrm{~J})$ & -- & -- \\
\hline & VWDRP008 & 3.0 & 5.0 & $4.3(\mathrm{~J})$ & $110(\mathrm{~J})$ & $5.4(\mathrm{~J})$ & $6.7(\mathrm{~J})$ & -- & -- \\
\hline \multirow{2}{*}{ GP3 } & VWDRP009 & 0.0 & 1.0 & $3.3(\mathrm{~J})$ & $106(\mathrm{~J})$ & $5.8(\mathrm{~J})$ & $7.1(\mathrm{~J})$ & $\overline{--}$ & $\overline{--}$ \\
\hline & VWDRP010 & 3.0 & 5.0 & $3.5(\mathrm{~J})$ & $88.1(\mathrm{~J})$ & $4.2(\mathrm{~J})$ & $6.4(\mathrm{~J})$ & -- & -- \\
\hline \multirow{3}{*}{ GP4 } & VWDRP011 & 0.0 & 1.0 & $3.7(\mathrm{~J})$ & $96.1(\mathrm{~J})$ & $5.2(\mathrm{~J})$ & $13.2(\mathrm{~J})$ & -- & -- \\
\hline & VWDRPX11 & 0.0 & 1.0 & $3.4(\mathrm{~J})$ & $82.8(\mathrm{~J})$ & $6(\mathrm{~J})$ & $33.2(\mathrm{~J})$ & -- & -- \\
\hline & VWDRP012 & 3.0 & 5.0 & $3.9(\mathrm{~J})$ & $120(\mathrm{~J})$ & $5.1(\mathrm{~J})$ & $7(\mathrm{~J})$ & -- & -- \\
\hline \multirow{2}{*}{ GP5 } & VWDRP013 & 0.0 & 1.0 & $2.8(\mathrm{~J})$ & $100(\mathrm{~J})$ & $5.6(\mathrm{~J})$ & $6.9(\mathrm{~J})$ & -- & -- \\
\hline & VWDRP014 & 3.0 & 5.0 & $3.8(\mathrm{~J})$ & $104(\mathrm{~J})$ & $4.8(\mathrm{~J})$ & $6.3(\mathrm{~J})$ & -- & -- \\
\hline \multirow{2}{*}{ GP6 } & VWDRP015 & 0.0 & 1.0 & $3.7(\mathrm{~J})$ & $117(\mathrm{~J})$ & $6.1(\mathrm{~J})$ & $8.8(\mathrm{~J})$ & -- & -- \\
\hline & VWDRP020 & 3.0 & 5.0 & $3(\mathrm{~J})$ & $104(\mathrm{~J})$ & $4.3(\mathrm{~J})$ & $6(\mathrm{~J})$ & -- & -- \\
\hline \multirow{2}{*}{ GP7 } & VWDRP021 & 0.0 & 1.0 & $4(\mathrm{~J})$ & $101(\mathrm{~J})$ & $5.8(\mathrm{~J})$ & $8.2(\mathrm{~J})$ & -- & -- \\
\hline & VWDRP022 & 3.0 & 5.0 & $5.3(\mathrm{~J})$ & $281(\mathrm{~J})$ & $4.9(\mathrm{~J})$ & $6.7(\mathrm{~J})$ & -- & -- \\
\hline \multirow{2}{*}{ GP8 } & VWDRP023 & 0.0 & 1.0 & $3.9(\mathrm{~J})$ & $113(\mathrm{~J})$ & $5.7(\mathrm{~J})$ & $8.3(\mathrm{~J})$ & $\overline{--}$ & -- \\
\hline & VWDRP024 & 3.0 & 5.0 & $3.8(\mathrm{~J})$ & $293(\mathrm{~J})$ & $3.8(\mathrm{~J})$ & $5.8(\mathrm{~J})$ & -- & -- \\
\hline \multirow{2}{*}{ GP9 } & VWDRP025 & 0.0 & 1.0 & $3.8(\mathrm{~J})$ & $114(\mathrm{~J})$ & $5(\mathrm{~J})$ & $6.2(\mathrm{~J})$ & -- & -- \\
\hline & VWDRP026 & 3.0 & 5.0 & $4.9(\mathrm{~J})$ & $116(\mathrm{~J})$ & $4.9(\mathrm{~J})$ & $8(\mathrm{~J})$ & -- & -- \\
\hline
\end{tabular}

aEPA Region 9 Industrial PRGs (EPA, 1998)

$\mathrm{J}=$ Estimated value

$\mathrm{B}=$ Reported value is less than the Contract Required Detection Limit but greater than the Instrument Detection Limit

-- = Not detected above minimum reporting limit 
Table A.3-6

Summary of Total Pesticides Results Detected Above Minimum Reporting Limits, Area 25 Vehicle Washdown, Nevada Test Site

\begin{tabular}{|c|c|c|c|c|c|c|c|}
\hline \multirow{2}{*}{$\begin{array}{l}\text { Sample } \\
\text { Location }\end{array}$} & \multirow{2}{*}{$\begin{array}{c}\text { Sample } \\
\text { No. }\end{array}$} & \multirow{2}{*}{$\begin{array}{c}\text { Start Depth } \\
\text { (ft) }\end{array}$} & \multirow{2}{*}{$\begin{array}{l}\text { End Depth } \\
\text { (ft) }\end{array}$} & \multicolumn{4}{|c|}{ Contaminants of Potential Concern $(\mu \mathrm{g} / \mathrm{kg})$} \\
\hline & & & & 4,4'-DDD & 4,4'-DDE & 4,4'-DDT & Chlordane \\
\hline \multicolumn{4}{|c|}{ Preliminary Action Levels ${ }^{a}$} & 19,000 & 13,000 & 13,000 & 12,000 \\
\hline \multicolumn{8}{|c|}{ CAS 25-07-03 RADSAFE Pad } \\
\hline GP1 & VWDRP005 & 0.0 & 1.0 & -- & -- & 4.8 & -- \\
\hline GP2 & VWDRP007 & 0.0 & 1.0 & $4.4(\mathrm{~J})$ & 23 & 83 & 20.8 \\
\hline GP4 & VWDRP011 & 0.0 & 1.0 & -- & 29 & 59 & 33 \\
\hline GP5 & VWDRP013 & 0.0 & 1.0 & -- & 27 & 63 & 33 \\
\hline \multicolumn{8}{|c|}{ CAS 25-07-01 Propellant Pad } \\
\hline GP5 & VWDRP017 & 0.0 & 1.0 & -- & -- & 3.7 & -- \\
\hline
\end{tabular}

aEPA Region 9 Industrial PRGs (EPA, 1998)

$\mathrm{J}=$ Estimated value

-- = Not detected above minimum reporting limit $\mu \mathrm{g} / \mathrm{kg}=$ Micrograms per kilogram DDD = dichlorodiphenyldichloroethane DDE $=$ dichlorodiphenyldicloroethylene DDT $=$ dichlorodiphenyltrichloroethylene

\section{A.3.7 Gamma Spectrometry Results}

The radionuclides detected in soil using gamma spectrometry at concentrations above the minimum reporting limits as specified in the CAIP (DOE/NV, 1999) are presented in Table A.3-7. Sample VWDFJ013, from the F and J Roads Pad, had a cesium-137 concentration above established background levels and; therefore, above PALs (DOE/NV, 1999). All other results are considered not to be statistically different from their respective established background levels.

\section{A.3.8 Isotopic Uranium, Isotopic Plutonium, and Strontium-90 Results}

Sample VWDFJ013 was analyzed for isotopic uranium and plutonium because gamma spectrometry indicated the presence of cesium-137 above PALs (DOE/NV, 1999). Selected samples were analyzed for strontium-90. Analytical results exceeding minimum reporting limits (DOE/NV, 1999) for these parameters are presented in Table A.3-8. Samples VWDFJ011 and VWDFJ013, from the F and J Roads Pad, had strontium-90 concentrations above established background levels and; therefore, above PALs (DOE/NV, 1999). All other results are considered not to be statistically different from their respective established background levels. 
Table A.3-7

Soil Sample Results for Gamma Spectrometry Above Contract Required Detection Limit, Area 25 Vehicle Washdown, Nevada Test Site

(Page 1 of 4 )

\begin{tabular}{|c|c|c|c|c|c|c|c|c|c|}
\hline \multirow{2}{*}{$\begin{array}{l}\text { Sample } \\
\text { Location }\end{array}$} & \multirow{2}{*}{ Sample No. } & \multirow{2}{*}{$\begin{array}{c}\text { Start } \\
\text { Depth (ft) }\end{array}$} & \multirow{2}{*}{$\begin{array}{l}\text { End } \\
\text { Depth (ft) }\end{array}$} & \multicolumn{6}{|c|}{ Contaminant of Potential Concern $(\mathrm{pCi} / \mathrm{g})$} \\
\hline & & & & Cesium-137 & Bismuth-214 & Potassium-40 & Radium-226 & Thorium-228 & Thorium-232 \\
\hline \multicolumn{4}{|c|}{ Background Concentrations } & $0.04-7.0^{\mathrm{a}}$ & $0.1-3.47^{b}$ & $11-96^{b}$ & $0.21-3.21^{\mathrm{a}}$ & $0.49-2.4^{a}$ & $0.49-2.4^{a}$ \\
\hline \multicolumn{10}{|c|}{ CAS 25-07-01 Propellant Pad } \\
\hline \multirow{2}{*}{ BKG1 } & VWDPP001 & 0.0 & 1.0 & -- & $\overline{--}$ & $32.46 \pm 5.66(\mathrm{~J})$ & $1.32 \pm 0.34(\mathrm{~J})$ & $2.35 \pm 0.45(\mathrm{~J})$ & $1.80 \pm 0.64(\mathrm{~J})$ \\
\hline & VWDPP002 & 3.0 & 5.0 & -- & -- & $30.69 \pm 5.45(\mathrm{~J})$ & $0.88 \pm 0.30(\mathrm{~J})$ & $2.65 \pm 0.48(\mathrm{~J})$ & $1.63 \pm 0.60(\mathrm{~J})$ \\
\hline \multirow{2}{*}{ BKG2 } & VWDPP003 & 0.0 & 1.0 & $\overline{--}$ & -- & $34.81 \pm 5.93(\mathrm{~J})$ & $1.08 \pm 0.31(\mathrm{~J})$ & $2.49 \pm 0.46(\mathrm{~J})$ & $1.88 \pm 0.65(\mathrm{~J})$ \\
\hline & VWDPP004 & 3.0 & 5.0 & $\overline{--}$ & $\overline{--}$ & $30.78 \pm 5.46(\mathrm{~J})$ & $1.00 \pm 0.31(\mathrm{~J})$ & $2.67 \pm 0.47(\mathrm{~J})$ & $1.86 \pm 0.62(\mathrm{~J})$ \\
\hline \multirow{2}{*}{ GP1 } & VWDPP008 & 0.0 & 1.0 & -- & -- & $26.16 \pm 4.92(\mathrm{~J})$ & $0.87 \pm 0.29(\mathrm{~J})$ & $2.49 \pm 0.46(\mathrm{~J})$ & $2.51 \pm 0.76(\mathrm{~J})$ \\
\hline & VWDPP009 & 3.0 & 5.0 & -- & -- & $29.90 \pm 5.35(\mathrm{~J})$ & $1.14 \pm 0.32(\mathrm{~J})$ & $2.64 \pm 0.47(\mathrm{~J})$ & $1.64 \pm 0.60(\mathrm{~J})$ \\
\hline \multirow{2}{*}{ GP2 } & VWDPP010 & 0.0 & 1.0 & $\overline{--}$ & -- & $29.99 \pm 5.42(\mathrm{~J})$ & $1.01 \pm 0.30(\mathrm{~J})$ & $2.45 \pm 0.46(\mathrm{~J})$ & $2.34 \pm 0.72(\mathrm{~J})$ \\
\hline & VWDPP011 & 3.0 & 5.0 & -- & -- & $27.65 \pm 5.19(\mathrm{~J})$ & $0.81 \pm 0.28(\mathrm{~J})$ & $2.59 \pm 0.47(\mathrm{~J})$ & $1.90 \pm 0.66(\mathrm{~J})$ \\
\hline \multirow{2}{*}{ GP3 } & VWDPP012 & 0.0 & 1.0 & -- & -- & $31.60 \pm 5.56(\mathrm{~J})$ & $0.86 \pm 0.30(\mathrm{~J})$ & $2.54 \pm 0.46(\mathrm{~J})$ & $2.10 \pm 0.66(\mathrm{~J})$ \\
\hline & VWDPP013 & 3.0 & 5.0 & -- & -- & $33.49 \pm 5.78(\mathrm{~J})$ & $0.82 \pm 0.28(\mathrm{~J})$ & $2.44 \pm 0.45(\mathrm{~J})$ & $2.05 \pm 0.67(\mathrm{~J})$ \\
\hline \multirow{3}{*}{ GP4 } & VWDPP014 & 0.0 & 1.0 & $\overline{--}$ & $\overline{--}$ & $29.29 \pm 5.30(\mathrm{~J})$ & $1.22 \pm 0.33(\mathrm{~J})$ & $2.32 \pm 0.44(\mathrm{~J})$ & $2.30 \pm 0.72(\mathrm{~J})$ \\
\hline & VWDPP015 & 3.0 & 5.0 & -- & -- & $28.23 \pm 5.16(\mathrm{~J})$ & $1.04 \pm 0.30(\mathrm{~J})$ & $2.43 \pm 0.45(\mathrm{~J})$ & $2.17 \pm 0.67(\mathrm{~J})$ \\
\hline & VWDPP016 & 3.0 & 5.0 & -- & -- & $32.06 \pm 5.62(\mathrm{~J})$ & $0.82 \pm 0.29(\mathrm{~J})$ & $2.40 \pm 0.45(\mathrm{~J})$ & $2.30 \pm 0.70(\mathrm{~J})$ \\
\hline \multirow{2}{*}{ GP5 } & VWDPP017 & 0.0 & 1.0 & $\overline{--}$ & $\overline{--}$ & $31.83 \pm 5.62(\mathrm{~J})$ & $0.97 \pm 0.31(\mathrm{~J})$ & $2.54 \pm 0.47(\mathrm{~J})$ & $1.99 \pm 0.66(\mathrm{~J})$ \\
\hline & VWDPP018 & 3.0 & 5.0 & $\overline{--}$ & $\overline{--}$ & $28.48 \pm 5.26(\mathrm{~J})$ & $0.85 \pm 0.28(\mathrm{~J})$ & $2.41 \pm 0.45(\mathrm{~J})$ & $2.22 \pm 0.70(\mathrm{~J})$ \\
\hline GP4 & VWDPP025 & 5.0 & 7.0 & $\overline{--}$ & $\overline{--}$ & $30.51 \pm 5.43(\mathrm{~J})$ & $1.24 \pm 0.32(\mathrm{~J})$ & $2.30 \pm 0.44(\mathrm{~J})$ & $1.51 \pm 0.56(\mathrm{~J})$ \\
\hline GP5 & VWDPP027 & 5.0 & 7.0 & -- & $\overline{--}$ & $29.34 \pm 5.31(\mathrm{~J})$ & $0.98 \pm 0.30(\mathrm{~J})$ & $2.67 \pm 0.48(\mathrm{~J})$ & $1.81 \pm 0.63(\mathrm{~J})$ \\
\hline GP6 & VWDPP028 & 0.0 & 1.0 & $\overline{--}$ & $\overline{--}$ & $34.65 \pm 5.93(\mathrm{~J})$ & $1.18 \pm 0.32(\mathrm{~J})$ & $2.67 \pm 0.48(\mathrm{~J})$ & $1.78 \pm 0.63(\mathrm{~J})$ \\
\hline GP7 & VWDPP030 & 0.0 & 1.0 & -- & -- & $29.49 \pm 5.34(\mathrm{~J})$ & $1.12 \pm 0.31(\mathrm{~J})$ & $2.29 \pm 0.44(\mathrm{~J})$ & $2.16 \pm 0.70(\mathrm{~J})$ \\
\hline GP8 & VWDPP032 & 0.0 & 1.0 & $\overline{--}$ & $\overline{--}$ & $33.13 \pm 5.75(\mathrm{~J})$ & $1.29 \pm 0.35(\mathrm{~J})$ & $2.77 \pm 0.50(\mathrm{~J})$ & $1.83 \pm 0.64(\mathrm{~J})$ \\
\hline
\end{tabular}


Table A.3-7

Soil Sample Results for Gamma Spectrometry Above Contract Required Detection Limit, Area 25 Vehicle Washdown, Nevada Test Site

(Page 2 of 4)

\begin{tabular}{|c|c|c|c|c|c|c|c|c|c|}
\hline \multirow{2}{*}{$\begin{array}{l}\text { Sample } \\
\text { Location }\end{array}$} & \multirow{2}{*}{ Sample No. } & \multirow{2}{*}{$\begin{array}{c}\text { Start } \\
\text { Depth (ft) }\end{array}$} & \multirow{2}{*}{$\begin{array}{c}\text { End } \\
\text { Depth (ft) }\end{array}$} & \multicolumn{6}{|c|}{ Contaminant of Potential Concern $(\mathrm{pCi} / \mathrm{g})$} \\
\hline & & & & Cesium-137 & Bismuth-214 & Potassium-40 & Radium-226 & Thorium-228 & Thorium-232 \\
\hline \multicolumn{4}{|c|}{ Background Concentrations } & $0.04-7.0^{\mathrm{a}}$ & $0.1-3.47^{b}$ & $11-96^{b}$ & $0.21-3.21^{\mathrm{a}}$ & $0.49-2.4^{a}$ & $0.49-2.4^{a}$ \\
\hline \multicolumn{10}{|c|}{ CAS 25-07-02 F and J Roads Pad } \\
\hline \multirow{2}{*}{ BKG1 } & VWDFJ001 & 0.0 & 1.0 & -- & $\overline{--}$ & $31.93 \pm 5.59(\mathrm{~J})$ & $1.25 \pm 0.35(\mathrm{~J})$ & $2.56 \pm 0.48(\mathrm{~J})$ & $2.30 \pm 0.71(\mathrm{~J})$ \\
\hline & VWDFJ002 & 3.0 & 5.0 & -- & -- & $35.49 \pm 6.02(\mathrm{~J})$ & $1.31 \pm 0.36(\mathrm{~J})$ & $3.01 \pm 0.54(\mathrm{~J})$ & $2.79 \pm 0.80(\mathrm{~J})$ \\
\hline \multirow{2}{*}{ BKG2 } & VWDFJ003 & 0.0 & 1.0 & $\overline{--}$ & -- & $32.44 \pm 5.69(\mathrm{~J})$ & $1.35 \pm 0.37(\mathrm{~J})$ & $3.18 \pm 0.55(\mathrm{~J})$ & $2.94 \pm 0.80(\mathrm{~J})$ \\
\hline & VWDFJ004 & 3.0 & 4.0 & -- & -- & $32.87 \pm 5.71(\mathrm{~J})$ & $1.20 \pm 0.36(\mathrm{~J})$ & $3.17 \pm 0.55(\mathrm{~J})$ & $3.16 \pm 0.85(\mathrm{~J})$ \\
\hline \multirow{2}{*}{ GP1 } & VWDFJ005 & 0.0 & 1.0 & -- & -- & $33.48 \pm 5.80(\mathrm{~J})$ & $1.17 \pm 0.36(\mathrm{~J})$ & $3.33 \pm 0.56(\mathrm{~J})$ & $3.50 \pm 0.89(\mathrm{~J})$ \\
\hline & VWDFJ006 & 3.0 & 5.0 & -- & -- & $37.31 \pm 6.30(\mathrm{~J})$ & $1.14 \pm 0.34(\mathrm{~J})$ & $3.52 \pm 0.59(\mathrm{~J})$ & $2.66 \pm 0.77(\mathrm{~J})$ \\
\hline \multirow{2}{*}{ GP2 } & VWDFJ007 & 0.0 & 1.0 & $\overline{--}$ & -- & $32.03 \pm 5.63(\mathrm{~J})$ & $1.18 \pm 0.35(\mathrm{~J})$ & $3.23 \pm 0.54(\mathrm{~J})$ & $2.22 \pm 0.70(\mathrm{~J})$ \\
\hline & VWDFJ008 & 3.0 & 5.0 & -- & -- & $34.58 \pm 5.92(\mathrm{~J})$ & $1.31 \pm 0.35(\mathrm{~J})$ & $2.70 \pm 0.50(\mathrm{~J})$ & $2.47 \pm 0.74(\mathrm{~J})$ \\
\hline \multirow{2}{*}{ GP3 } & VWDFJ009 & 0.0 & 1.0 & $0.20 \pm 0.11(\mathrm{~J})$ & -- & $25.99 \pm 4.90(\mathrm{~J})$ & $1.10 \pm 0.32(\mathrm{~J})$ & $2.48 \pm 0.46(\mathrm{~J})$ & $1.89 \pm 0.65(\mathrm{~J})$ \\
\hline & VWDFJ010 & 3.0 & 5.0 & -- & -- & $35.95 \pm 6.13(\mathrm{~J})$ & $1.36 \pm 0.36(\mathrm{~J})$ & $3.10 \pm 0.54(\mathrm{~J})$ & $2.35 \pm 0.72(\mathrm{~J})$ \\
\hline \multirow{2}{*}{ GP4 } & VWDFJ011 & 0.0 & 1.0 & $1.07 \pm 0.24(\mathrm{~J})$ & $\overline{--}$ & $23.71 \pm 4.60(\mathrm{~J})$ & $1.19 \pm 0.32(\mathrm{~J})$ & $2.25 \pm 0.44(\mathrm{~J})$ & $2.22 \pm 0.69(\mathrm{~J})$ \\
\hline & VWDFJ012 & 3.0 & 5.0 & -- & -- & $33.60 \pm 5.80(\mathrm{~J})$ & $1.09 \pm 0.33(\mathrm{~J})$ & $3.04 \pm 0.52(\mathrm{~J})$ & $2.42 \pm 0.73(\mathrm{~J})$ \\
\hline \multirow{2}{*}{ GP5 } & VWDFJ013 & 0.0 & 1.0 & $14.65 \pm 1.61(\mathrm{~J})$ & -- & $24.91 \pm 4.76(\mathrm{~J})$ & $0.98 \pm 0.36(\mathrm{~J})$ & $2.50 \pm 0.54(\mathrm{~J})$ & $1.75 \pm 0.63(\mathrm{~J})$ \\
\hline & VWDFJ014 & 3.0 & 5.0 & -- & -- & $35.71 \pm 6.07(\mathrm{~J})$ & $1.09 \pm 0.31(\mathrm{~J}$ & $3.22 \pm 0.55(\mathrm{~J})$ & $2.68 \pm 0.77(\mathrm{~J})$ \\
\hline \multirow{2}{*}{ GP6 } & VWDFJ015 & 0.0 & 1.0 & $0.45 \pm 0.15(\mathrm{~J})$ & $\overline{--}$ & $25.48 \pm 4.83(\mathrm{~J})$ & $1.26 \pm 0.34(\mathrm{~J})$ & $2.39 \pm 0.45(\mathrm{~J})$ & $1.69 \pm 0.61(\mathrm{~J})$ \\
\hline & VWDFJ016 & 3.0 & 5.0 & -- & -- & $30.68 \pm 5.47(\mathrm{~J})$ & $1.28 \pm 0.33(\mathrm{~J})$ & $2.79 \pm 0.51(\mathrm{~J})$ & $2.53 \pm 0.73(\mathrm{~J})$ \\
\hline \multirow{3}{*}{ GP7 } & VWDFJ017 & 0.0 & 1.0 & $3.45 \pm 0.54(\mathrm{~J})$ & $\overline{--}$ & $28.37 \pm 5.20(\mathrm{~J})$ & $0.95 \pm 0.31(\mathrm{~J})$ & $2.38 \pm 0.46(\mathrm{~J})$ & $1.74 \pm 0.63(\mathrm{~J})$ \\
\hline & VWDFJ018 & 3.0 & 5.0 & $0.53 \pm 0.17(\mathrm{~J})$ & -- & $33.44 \pm 5.81(\mathrm{~J})$ & $1.22 \pm 0.34(\mathrm{~J})$ & $2.96 \pm 0.53(\mathrm{~J})$ & $2.34 \pm 0.72(\mathrm{~J})$ \\
\hline & VWDFJ019 & 3.0 & 5.0 & -- & -- & $33.71 \pm 5.82(\mathrm{~J})$ & $1.33 \pm 0.34(\mathrm{~J})$ & $2.97 \pm 0.53(\mathrm{~J})$ & $2.24 \pm 0.71(\mathrm{~J})$ \\
\hline \multirow{2}{*}{ GP8 } & VWDFJ020 & 0.0 & 1.0 & -- & -- & $32.78 \pm 5.71(\mathrm{~J})$ & $1.27 \pm 0.34(\mathrm{~J})$ & $2.85 \pm 0.51(\mathrm{~J})$ & $2.30 \pm 0.71(\mathrm{~J})$ \\
\hline & VWDFJ021 & 3.0 & 5.0 & -- & -- & $33.50 \pm 5.80(\mathrm{~J})$ & $1.23 \pm 0.34(\mathrm{~J})$ & $3.06 \pm 0.54(\mathrm{~J})$ & $2.80 \pm 0.77(\mathrm{~J})$ \\
\hline \multirow{2}{*}{ GP9 } & VWDFJ022 & 0.0 & 1.0 & -- & -- & $28.13 \pm 5.14(\mathrm{~J})$ & $1.13 \pm 0.34(\mathrm{~J})$ & $2.18 \pm 0.43(\mathrm{~J})$ & $2.20 \pm 0.69(\mathrm{~J})$ \\
\hline & VWDFJ023 & 3.0 & 5.0 & -- & -- & $33.33 \pm 5.76(\mathrm{~J})$ & $1.30 \pm 0.35(\mathrm{~J})$ & $3.09 \pm 0.54(\mathrm{~J})$ & $2.38 \pm 0.72(\mathrm{~J})$ \\
\hline GP5 & VWDFJ024 & 5.0 & 7.0 & -- & $\overline{--}$ & $33.46 \pm 5.83(\mathrm{~J})$ & $1.16 \pm 0.33(\mathrm{~J})$ & $3.10 \pm 0.53(\mathrm{~J})$ & $3.03 \pm 0.82(\mathrm{~J})$ \\
\hline \multirow{2}{*}{$\mathrm{BKH} 1$} & VWDFJ025 & 0.0 & 1.0 & -- & -- & $30.60 \pm 5.43(\mathrm{~J})$ & $1.51 \pm 0.38(\mathrm{~J})$ & $2.91 \pm 0.51(\mathrm{~J})$ & $2.59 \pm 0.74(\mathrm{~J})$ \\
\hline & VWDFJ030 & 1.0 & 2.0 & -- & -- & $35.23 \pm 5.99(\mathrm{~J})$ & $1.16 \pm 0.32(\mathrm{~J})$ & $2.81 \pm 0.50(\mathrm{~J})$ & $2.59 \pm 0.75(\mathrm{~J})$ \\
\hline
\end{tabular}


Table A.3-7

Soil Sample Results for Gamma Spectrometry Above Contract Required Detection Limit, Area 25 Vehicle Washdown, Nevada Test Site

(Page 3 of 4)

\begin{tabular}{|c|c|c|c|c|c|c|c|c|c|}
\hline \multirow{2}{*}{$\begin{array}{c}\text { Sample } \\
\text { Location }\end{array}$} & \multirow{2}{*}{ Sample No. } & \multirow{2}{*}{$\begin{array}{c}\text { Start } \\
\text { Depth (ft) }\end{array}$} & \multirow{2}{*}{$\begin{array}{c}\text { End } \\
\text { Depth (ft) }\end{array}$} & \multicolumn{6}{|c|}{ Contaminant of Potential Concern $(\mathrm{pCi} / \mathrm{g})$} \\
\hline & & & & Cesium-137 & Bismuth-214 & Potassium-40 & Radium-226 & Thorium-228 & Thorium-232 \\
\hline \multicolumn{4}{|c|}{ Background Concentrations } & $0.04-7.0^{\mathrm{a}}$ & $0.1-3.47^{b}$ & $11-96^{b}$ & $0.21-3.21^{\mathrm{a}}$ & $0.49-2.4^{a}$ & $0.49-2.4^{a}$ \\
\hline$\overline{\mathrm{GP6}}$ & VWDFJ031 & 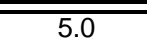 & $\overline{7.0}$ & $\overline{---}$ & $\overline{---}$ & $\overline{33.83 \pm 5.85(\mathrm{~J})}$ & 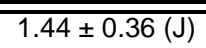 & $\overline{3.14 \pm 0.54(\mathrm{~J})}$ & $\overline{2.88 \pm 0.81(\mathrm{~J})}$ \\
\hline GP11 & VWDFJ032 & 0.0 & 1.0 & -- & $\overline{--}$ & $33.09 \pm 5.73(\mathrm{~J})$ & $1.21 \pm 0.34(\mathrm{~J})$ & $2.78 \pm 0.50(\mathrm{~J})$ & $2.17 \pm 0.69(\mathrm{~J}$ \\
\hline $\mathrm{BKH} 3$ & VWDFJ047 & 0.0 & 1.0 & -- & -- & $33.18 \pm 5.77(\mathrm{~J})$ & $1.41 \pm 0.35(\mathrm{~J})$ & $3.03 \pm 0.53(\mathrm{~J})$ & $2.81 \pm 0.79(\mathrm{~J}$ \\
\hline GP10 & VWDFJ048 & 0.0 & 1.0 & $\overline{--}$ & -- & $30.38 \pm 5.42(\mathrm{~J})$ & $1.37 \pm 0.39(\mathrm{~J})$ & $2.73 \pm 0.48(\mathrm{~J})$ & $2.08 \pm 0.67(\mathrm{~J}$ \\
\hline $\mathrm{BKH} 3$ & VWDFJ050 & 1.0 & 2.0 & $\overline{--}$ & $\overline{--}$ & $29.79 \pm 5.36(\mathrm{~J})$ & $1.42 \pm 0.36(\mathrm{~J})$ & $3.18 \pm 0.54(\mathrm{~J})$ & $2.22 \pm 0.68(\mathrm{~J}$ \\
\hline GP12 & VWDFJ051 & 0.0 & 1.0 & $\overline{--}$ & $\overline{--}$ & $32.46 \pm 5.67(\mathrm{~J})$ & $1.28 \pm 0.36(\mathrm{~J})$ & $2.58 \pm 0.48(\mathrm{~J})$ & $2.70 \pm 0.77(\mathrm{~J}$ \\
\hline \multirow{2}{*}{$\mathrm{BKH} 2$} & VWDFJ053 & 0.0 & 1.0 & -- & -- & $28.25 \pm 5.15(\mathrm{~J})$ & $1.23 \pm 0.33(\mathrm{~J})$ & $3.08 \pm 0.53(\mathrm{~J})$ & $2.63 \pm 0.74(\mathrm{~J}$ \\
\hline & VWDFJ054 & 1.0 & 2.0 & $\overline{--}$ & $\overline{--}$ & $35.20 \pm 6.00(\mathrm{~J})$ & $1.18 \pm 0.33(\mathrm{~J})$ & $3.21 \pm 0.54(\mathrm{~J})$ & $2.49 \pm 0.73(\mathrm{~J}$ \\
\hline $\mathrm{BKH3}$ & VWDFJ061 & 0.0 & 1.0 & -- & $\overline{--}$ & $31.52 \pm 5.76(\mathrm{~J})$ & $1.45 \pm 0.38(\mathrm{~J})$ & $3.25 \pm 0.53(\mathrm{~J})$ & $2.42 \pm 0.74(\mathrm{~J}$ \\
\hline GP3 & VWDFJX10 & 3.0 & 5.0 & -- & $1.22 \pm 0.32(\mathrm{~J})$ & $32.47 \pm 5.70(\mathrm{~J})$ & $\overline{--}$ & $2.73 \pm 0.50(\mathrm{~J})$ & $2.37 \pm 0.71(\mathrm{~J})$ \\
\hline \multicolumn{10}{|c|}{ CAS 25-07-03 RADSAFE Pad } \\
\hline \multirow{2}{*}{ BKG1 } & VWDRP001 & 0.0 & 1.0 & $\overline{--}$ & $\overline{--}$ & $27.95 \pm 5.12(\mathrm{~J})$ & $1.15 \pm 0.32(\mathrm{~J})$ & $2.52 \pm 0.46(\mathrm{~J})$ & $2.37 \pm 0.70(\mathrm{~J}$ \\
\hline & VWDRP002 & 3.0 & 5.0 & -- & -- & $29.75 \pm 5.37(\mathrm{~J})$ & $0.99 \pm 0.30(\mathrm{~J})$ & $2.30 \pm 0.42(\mathrm{~J})$ & $1.72 \pm 0.61(\mathrm{~J})$ \\
\hline \multirow{2}{*}{ BKG2 } & VWDRP003 & 0.0 & 1.0 & -- & -- & $29.31 \pm 5.28(\mathrm{~J})$ & $1.09 \pm 0.31(\mathrm{~J})$ & $2.50 \pm 0.46(\mathrm{~J})$ & $2.18 \pm 0.68(\mathrm{~J})$ \\
\hline & VWDRP004 & 3.0 & 5.0 & -- & -- & $27.29 \pm 5.06(\mathrm{~J})$ & $1.08 \pm 0.31(\mathrm{~J})$ & $2.19 \pm 0.43(\mathrm{~J})$ & $1.89 \pm 0.64(\mathrm{~J})$ \\
\hline \multirow{2}{*}{ GP1 } & VWDRP005 & 0.0 & 1.0 & $\overline{--}$ & $\overline{--}$ & $31.19 \pm 5.50(\mathrm{~J})$ & $1.18 \pm 0.34(\mathrm{~J})$ & $2.50 \pm 0.47(\mathrm{~J})$ & $2.47 \pm 0.75(\mathrm{~J}$ \\
\hline & VWDRP006 & 3.0 & 5.0 & -- & -- & $31.18 \pm 5.50(\mathrm{~J})$ & $1.07 \pm 0.32(\mathrm{~J})$ & $2.34 \pm 0.45(\mathrm{~J})$ & $2.22 \pm 0.70(\mathrm{~J})$ \\
\hline \multirow{2}{*}{ GP2 } & VWDRP007 & 0.0 & 1.0 & -- & $\overline{--}$ & $26.58 \pm 4.95(\mathrm{~J})$ & $1.12 \pm 0.32(\mathrm{~J})$ & $2.47 \pm 0.46(\mathrm{~J})$ & $2.09 \pm 0.67(\mathrm{~J})$ \\
\hline & VWDRP008 & 3.0 & 5.0 & -- & -- & $30.73 \pm 5.45(\mathrm{~J})$ & $1.27 \pm 0.34(\mathrm{~J})$ & $2.35 \pm 0.45(\mathrm{~J})$ & $1.78 \pm 0.62(\mathrm{~J})$ \\
\hline \multirow{2}{*}{ GP3 } & VWDRP009 & 0.0 & 1.0 & -- & -- & $34.22 \pm 5.87(\mathrm{~J})$ & $1.38 \pm 0.35(\mathrm{~J})$ & $2.59 \pm 0.48(\mathrm{~J})$ & $2.17 \pm 0.67(\mathrm{~J})$ \\
\hline & VWDRP010 & 3.0 & 5.0 & -- & -- & $31.40 \pm 5.54(\mathrm{~J})$ & $1.07 \pm 0.31(\mathrm{~J})$ & $2.58 \pm 0.47(\mathrm{~J})$ & $1.46 \pm 0.55(\mathrm{~J})$ \\
\hline \multirow{2}{*}{ GP4 } & VWDRP011 & 0.0 & 1.0 & -- & -- & $24.58 \pm 4.70(\mathrm{~J})$ & $1.13 \pm 0.32(\mathrm{~J})$ & $2.37 \pm 0.44(\mathrm{~J})$ & $1.74 \pm 0.63(\mathrm{~J}$ \\
\hline & VWDRP012 & 3.0 & 5.0 & -- & -- & $29.77 \pm 5.32(\mathrm{~J})$ & $1.27 \pm 0.33(\mathrm{~J})$ & $2.01 \pm 0.41(\mathrm{~J})$ & $2.07 \pm 0.67(\mathrm{~J}$ \\
\hline \multirow{2}{*}{ GP5 } & VWDRP013 & 0.0 & 1.0 & -- & -- & $32.78 \pm 5.70(\mathrm{~J})$ & $1.01 \pm 0.30(\mathrm{~J})$ & $2.69 \pm 0.48(\mathrm{~J})$ & $2.10 \pm 0.66(\mathrm{~J})$ \\
\hline & VWDRP014 & 3.0 & 5.0 & -- & -- & $26.15 \pm 4.90(\mathrm{~J})$ & $1.13 \pm 0.31(\mathrm{~J})$ & $2.20 \pm 0.42(\mathrm{~J})$ & $1.60 \pm 0.59(\mathrm{~J})$ \\
\hline \multirow{2}{*}{ GP6 } & VWDRP015 & 0.0 & 1.0 & -- & -- & $30.44 \pm 5.41(\mathrm{~J})$ & $1.45 \pm 0.37(\mathrm{~J})$ & $2.54 \pm 0.46(\mathrm{~J})$ & $2.29 \pm 0.68(\mathrm{~J})$ \\
\hline & VWDRP020 & 3.0 & 5.0 & -- & -- & $28.39 \pm 5.17(\mathrm{~J})$ & $0.90 \pm 0.28(\mathrm{~J})$ & $2.35 \pm 0.44(\mathrm{~J})$ & $2.18 \pm 0.68(\mathrm{~J})$ \\
\hline
\end{tabular}


Table A.3-7

Soil Sample Results for Gamma Spectrometry Above Contract Required Detection Limit, Area 25 Vehicle Washdown, Nevada Test Site

(Page 4 of 4 )

\begin{tabular}{|c|c|c|c|c|c|c|c|c|c|}
\hline \multirow{2}{*}{$\begin{array}{l}\text { Sample } \\
\text { Location }\end{array}$} & \multirow{2}{*}{ Sample No. } & \multirow{2}{*}{$\begin{array}{c}\text { Start } \\
\text { Depth (ft) }\end{array}$} & \multirow{2}{*}{$\begin{array}{c}\text { End } \\
\text { Depth (ft) }\end{array}$} & \multicolumn{6}{|c|}{ Contaminant of Potential Concern $(\mathrm{pCi} / \mathrm{g})$} \\
\hline & & & & Cesium-137 & Bismuth-214 & Potassium-40 & Radium-226 & Thorium-228 & Thorium-232 \\
\hline \multicolumn{4}{|c|}{ Background Concentrations } & $0.04-7.0^{\mathrm{a}}$ & $0.1-3.47^{b}$ & $11-96^{b}$ & $0.21-3.21^{a}$ & $0.49-2.4^{a}$ & $0.49-2.4^{a}$ \\
\hline \multirow{2}{*}{ GP7 } & VWDRP021 & 0.0 & 1.0 & $\overline{---}$ & $\overline{---}$ & $28.41 \pm 5.17(\mathrm{~J})$ & $1.36 \pm 0.36(\mathrm{~J})$ & $2.14 \pm 0.43(\mathrm{~J})$ & $2.37 \pm 0.70(\mathrm{~J}$ \\
\hline & VWDRP022 & 3.0 & 5.0 & -- & $\overline{--}$ & $28.49 \pm 5.20(\mathrm{~J})$ & $1.00 \pm 0.30(\mathrm{~J})$ & $2.54 \pm 0.45(\mathrm{~J})$ & $1.43 \pm 0.57(\mathrm{~J})$ \\
\hline \multirow{2}{*}{ GP8 } & VWDRP023 & 0.0 & 1.0 & -- & -- & $31.98 \pm 5.60(\mathrm{~J})$ & $1.41 \pm 0.32(\mathrm{~J})$ & $2.37 \pm 0.45(\mathrm{~J})$ & $1.78 \pm 0.63(\mathrm{~J})$ \\
\hline & VWDRP024 & 3.0 & 5.0 & -- & -- & $32.50 \pm 5.67(\mathrm{~J})$ & $1.16 \pm 0.33(\mathrm{~J})$ & $2.51 \pm 0.45(\mathrm{~J})$ & $2.07 \pm 0.67(\mathrm{~J})$ \\
\hline \multirow{2}{*}{ GP9 } & VWDRP025 & 0.0 & 1.0 & $\overline{--}$ & -- & $32.73 \pm 5.70(\mathrm{~J})$ & $1.25 \pm 0.34(\mathrm{~J})$ & $2.52 \pm 0.47(\mathrm{~J})$ & $2.05 \pm 0.67(\mathrm{~J})$ \\
\hline & VWDRP026 & 3.0 & 5.0 & -- & -- & $27.63 \pm 5.08(\mathrm{~J})$ & $0.91 \pm 0.30(\mathrm{~J})$ & $2.35 \pm 0.43(\mathrm{~J})$ & $1.36 \pm 0.54(\mathrm{~J})$ \\
\hline GP4 & VWDRPX11 & 0.0 & 1.0 & -- & -- & $29.87 \pm 5.47(\mathrm{~J})$ & $1.17 \pm 0.33(\mathrm{~J})$ & $2.55 \pm 0.48(\mathrm{~J})$ & $1.87 \pm 0.64(\mathrm{~J}$ \\
\hline
\end{tabular}

aBackground concentration listed or derived in Off-Site Radiation Exposure Review Project, Phase II Soils Program (McArthur and Miller, 1989)

${ }^{b}$ Background concentration listed in Environmental Monitoring Report for the Proposed Ward Valley California Low-Level Radioactive Waste (LLRW) Facility (Atlan-Tech, 1992)

$\mathrm{J}=$ Estimated value

$--=$ Not detected above contract required detection limit

$\mathrm{pCi} / \mathrm{g}=$ Picocuries per gram 
Table A.3-8

Soil Sample Results for Isotopic Uranium and Strontium-90 Detected Above Contract Required Detection Limit, Area 25 Vehicle Washdown, Nevada Test Site

\begin{tabular}{|c|c|c|c|c|c|c|}
\hline \multirow{2}{*}{$\begin{array}{l}\text { Sample } \\
\text { Location }\end{array}$} & \multirow{2}{*}{ Sample No. } & \multirow{2}{*}{$\begin{array}{l}\text { Start Depth } \\
\text { (ft) }\end{array}$} & \multirow{2}{*}{$\begin{array}{l}\text { End Depth } \\
\text { (ft) }\end{array}$} & \multicolumn{3}{|c|}{ Contaminant of Potential Concern (pCi/g) } \\
\hline & & & & Uranium-234 & Uranium-238 & Strontium-90 \\
\hline \multicolumn{4}{|c|}{ Background Concentrations } & $0.1-2.6^{a}$ & $0.21-3.2^{\mathrm{a}}$ & $0.01-1.17^{\mathrm{b}}$ \\
\hline \multicolumn{7}{|c|}{ CAS 25-07-02 F and J Roads Pad } \\
\hline BKG1 & VWDFJ001 & 0.0 & 1.0 & $0.89 \pm 0.17(\mathrm{~J})$ & $0.86 \pm 0.16(\mathrm{~J})$ & -- \\
\hline BKG2 & VWDFJ004 & 3.0 & 4.0 & $0.88 \pm 0.15(\mathrm{~J})$ & -- & -- \\
\hline GP5 & VWDFJ013 & 0.0 & 1.0 & $1.06 \pm 0.17(\mathrm{~J})$ & $0.87 \pm 0.15(J)$ & $12.5 \pm 2.3(\mathrm{~J})$ \\
\hline GP4 & VWDFJ011 & 0.0 & 1.0 & -- & -- & $6.9 \pm 1.3(\mathrm{~J})$ \\
\hline \multicolumn{7}{|c|}{ CAS 25-07-03 RADSAFE Pad } \\
\hline BKG1 & VWDRP002 & 3.0 & 5.0 & $0.99 \pm 0.19$ & $1.03 \pm 0.19$ & -- \\
\hline
\end{tabular}

aBackground concentration listed or derived in Off-Site Radiation Exposure Review Project, Phase I/ Soils Program (McArthur and Miller, 1989)

${ }^{b}$ Background concentration listed in Environmental Monitoring Report for the Proposed Ward Valley California Low-Level Radioactive Waste (LLRW) Facility (Atlan-Tech, 1992)

$\mathrm{J}=$ Estimated value

-- = Not detected above contract required detection limit

Shading indicates analytical result exceeds PAL. 


\section{A.4.0 Quality Assurance}

The results of the QA/QC activities for the Area 25 Vehicle Washdown corrective action investigation sampling events are summarized in the following text. Detailed information regarding the QA program is contained in the Industrial Sites QAPP (DOE/NV, 1996).

Quality control results are typically judged in terms of precision, accuracy, representativeness, completeness, and comparability and are described in the following sections.

\section{A.4.1 Precision}

Precision is a quantitative measure of the variability of a group of measurements from their average value. Precision is assessed for inorganic analysis by collecting and analyzing duplicate field samples and comparing the results with the original sample. Precision is also assessed by creating, preparing, analyzing, and comparing laboratory duplicates from one or more field samples in inorganic analyses and matrix spike and matrix spike duplicate (MS/MSD) samples for organic analyses. Precision is reported as relative percent difference (RPD) which is calculated as the difference between the measured concentrations of duplicate samples, divided by the average of the two concentrations, and multiplied by 100. Any deviation from these requirements has been documented and explained and the related data qualified accordingly. The qualification process is described in Section A.4.7.1.

\section{A.4.2 Accuracy}

Analytical accuracy is defined as the nearness of a measurement to the true or accepted reference value. It is the composite of the random and systematic components of the measurement system and measures bias in the measurement system. The random component of accuracy is measured and documented through the analyses of spiked samples. Sampling accuracy is assessed by evaluating the results of spiked samples and laboratory control samples. Accuracy measurements are calculated as percent recovery by dividing the measured sample concentration by the true concentration and multiplying the quotient by 100 .

Field accuracy is assessed by confirming that the documents of record track the sample from origin, through transfer of custody, to disposal. The goal of field accuracy is for all samples to be collected 
from the correct locations at the correct time, placed in a correctly labeled container with the correct preservative, and sealed with custody tape to prevent tampering. All samples in this sampling event were properly collected and custody was maintained during shipment to the laboratories.

\section{A.4.3 Representativeness}

Representativeness expresses the degree to which sample data accurately and precisely represent a characteristic of a population, parameter variations at a sampling point, or an environmental condition (EPA, 1987). Sample representativeness was achieved through the implementation of a sampling program designed to ensure proper sampling locations, number of samples, and the use of validated analytical methods. Representativeness was assessed through analysis of duplicate samples. Representativeness of the samples taken in this sampling event was assured by collecting the specified number of samples (DOE/NV, 1999) and by analyzing them by the approved analytical methods shown in Table A.3-2.

\section{A.4.4 Completeness}

Completeness is defined as a percentage of measurements made that are judged to be valid. A sampling and analytical requirement of 80 percent completeness was established for this project (DOE/NV, 1996). Although a portion of the results for acrolein were rejected, the minimum 80 percent completeness was achieved. Please refer to Section A.3.1 for more information regarding rejected data for acrolein.

The specified sampling locations were utilized as planned. All samples were collected as specified in the CAIP (DOE/NV, 1999), and all sample containers reached the laboratory intact and properly preserved (when applicable). Sample temperatures were maintained during shipment to the laboratory, and sample chain of custody was maintained during sample storage and/or shipment.

\section{A.4.5 Comparability}

Comparability is a qualitative parameter expressing the confidence with which one data set can be compared to another (EPA, 1987). To ensure comparability, the Area 25 Vehicle Washdown field and sampling activities were performed and documented in accordance with approved procedures, and all samples were collected in accordance with the CAIP (DOE/NV, 1999). Approved 
standardized methods and procedures were also used to analyze and report the data (e.g., Contract Laboratory Program [CLP] and/or CLP-like data packages). This approach ensures that the data from this project can be compared to other data sets. Based on the minimum comparability requirements specified in the Industrial Sites QAPP (DOE/NV, 1996), all requirements were met.

Field (i.e., sample-handling) documentation, laboratory nonconformance reports, and the precision and accuracy of quality-control sample results were evaluated for their effect on the results of the associated environmental soil samples. The environmental sample results were then qualified according to processes outlined in the following sections. Documentation of the data qualifications resulting from these reviews is retained in project files as both hard copy and electronic media.

\section{A.4.6 Tier I and Tier II Data Evaluations}

All laboratory data from samples collected at CAU 240 have been evaluated for data quality according to the EPA Functional Guidelines (EPA, 1994b and 1994c). These guidelines are implemented in a tiered process and are presented in the following text. No data rejected during the data evaluation process were used to draw the conclusions presented in the CADD. Only valid data, whether estimated (i.e., J-qualified) or not, were used.

Changes resulting from the data evaluation process are documented in project files and are summarized in memoranda for each sample delivery group (SDG). These memoranda are maintained in IT project files.

\section{A.4.6.1 Tier I Evaluation}

Tier I evaluation for both chemical and radiological analyses examines (but is not limited to):

- Sample count/type consistent with chain of custody

- Analysis count/type consistent with chain of custody

- Correct sample matrix

- Significant problems stated in cover letter or case narrative

- Completeness of certificates of analysis

- Completeness of CLP or CLP-like packages

- Completeness of signatures, dates, and times on chain of custody

- Condition-upon-receipt variance form included

- Requested analyses performed on all samples 
- Date received/analyzed given for each sample

- Correct concentration units indicated

- Electronic data transfer supplied

- Results reported for field and laboratory QC samples

- Whether or not the deliverable met the overall objectives of the project

\section{A.4.6.2 Tier II Evaluation}

Tier II evaluation for both chemical and radiological analyses examines (but is not limited to):

\section{Chemical:}

- Correct detection limits achieved

- Sample date, preparation date, and analysis date for each sample

- Holding time criteria met

- QC batch association for each sample

- Cooler temperature upon receipt

- Sample $\mathrm{pH}$ for aqueous samples, as required

- Detection limits properly adjusted for dilution, as required

- Blank contamination evaluated and applied to sample results/qualifiers

- $\quad$ MS/MSD percent recoveries (\%R) and RPDs evaluated and applied to laboratory results/qualifiers

- Field duplicate RPDs evaluated using professional judgement and applied to laboratory results/qualifiers

- Laboratory duplicate RPDs evaluated and applied to laboratory results/qualifiers

- Surrogate \%Rs evaluated and applied to laboratory results/qualifiers

- Laboratory control sample \%R evaluated and applied to laboratory results/qualifiers

- Initial and continuing calibration evaluated and applied to laboratory results/qualifiers

- Internal standard evaluated and applied to laboratory results/qualifiers

- Recalculation of 10 percent of laboratory results from raw data

\section{Radioanalytical:}

- Correct detection limits achieved

- Blank contamination evaluated and applied to sample results/qualifiers

- Certificate of Analysis consistent with data package documentation 
- Quality control sample results (duplicates, laboratory control samples, laboratory blanks) evaluated and applied to laboratory result qualifiers

- Sample results, error, and minimum detectable activity evaluated and applied to laboratory result qualifiers

- Detector system calibrated to National Institute for Standards and Technology (NIST) traceable sources

- Calibration sources preparation was documented, demonstrating proper preparation and appropriateness for sample matrix, emission energies, and concentrations

- Detector system response to daily, weekly, and monthly background and calibration checks for peak energy, peak centroid, peak full-width half-maximum, and peak efficiency

- Tracers NIST-traceable, appropriate for the analysis performed, and recoveries that met QC requirements

- Documentation of all QC sample preparation complete and properly performed

- Spectra lines, emissions, particle energies, peak areas, and background peak areas support the identified radionuclide and its concentration

\section{A.4.6.3 Tier III}

Data quality considerations that are included in EPA data review functional guidelines (EPA, 1994b and 1994c) as a Tier III review include the additional evaluations:

\section{Chemical:}

- Mass spectrometer tuning criteria

- Initial and continuing calibration verification

- Internal standard evaluation

- Organic compound quantitation

- Inductively coupled plasma (ICP) interference check sample evaluation

- Graphite furnace atomic absorption quality control

- ICP serial dilution effects

- Recalculation of all laboratory results from raw data

\section{Radioanalytical:}

- QC sample results (e.g., calibration source concentration, percent recovery, and RPD) verified

- Radionuclides and their concentration appropriate considering their decay schemes, half-lives, and process knowledge and history of the facility and site

- Each identified line in spectra verified against emission libraries and calibration results

- Independent identification of spectra lines, area under the peaks, and quantification of radionuclide concentration in a random number of sample results 
A Tier III review of at least 5 percent of the sample analytical data is currently being performed by Laboratory Data Consultants, Inc. in Carlsbad, California. Results will be incorporated in the final version of this document.

\section{A.4.7 Quality Control Samples}

Twenty-six trip blanks, four field blanks, five equipment rinsate blanks, five MS/MSD, and five field duplicates were collected and submitted for laboratory analyses as shown in Table A.3-1. The blanks and duplicates were assigned individual sample numbers and sent to the laboratory "blind." Additional samples were selected by the laboratory to be analyzed as laboratory duplicates. Documentation related to the collection and analyses of these samples is retained in project files.

\section{A.4.7.1 Field Quality Control Samples}

Review of the field-collected blank analytical data for the investigation sampling indicates that cross-contamination from field methods did not occur during sample collection. Field and equipment rinsate blanks were analyzed for the parameters listed in Table A.3-2 and trip blanks were analyzed for VOCs only. None of the results for these field-collected blanks exceeded the minimum laboratory reporting limits (DOE/NV, 1999).

During the sampling event, five field duplicate soil samples were sent as blind samples to the laboratory to be analyzed for the investigation parameters listed in Table A.3-2. For these samples, the duplicate results precision (i.e., RPDs between the environmental sample results and their corresponding field duplicate sample results) were evaluated to the guidelines set forth in EPA Functional Guidelines (EPA, 1994b and 1994c). The EPA Functional Guidelines state that there are no required review criteria for field duplicate analyses comparability, but allow the data reviewer to exercise professional judgement. The RPD between the environmental samples results and their corresponding field duplicate sample results exceeded the 20 percent criteria stated in the Industrial Sites QAPP (DOE/NV, 1996) for some target analytes. The variability in the results between the environmental samples and their corresponding field duplicate samples could be attributed to nonhomogeneous samples and the difficulties associated with collecting identical field samples. It is expected that soil field duplicate results will have a greater variance than water matrices. 
The laboratory duplicate samples were compared to the criteria set forth in the EPA Functional Guidelines (EPA, 1994c) and the associated sample results were qualified accordingly. Both detections and nondetections have been qualified as estimated ( $\mathrm{J}$ and $\mathrm{UJ}$, respectively) if the relative percent difference between an environmental sample and its laboratory duplicate fell outside established criteria.

Five field samples were selected for use as MS/MSD samples. The percent recoveries of these samples (a measure of accuracy) and the relative percent differences in these sample results (a measure of precision) were compared to EPA Functional Guideline criteria (EPA, 1994b and 1994c). The results were used to qualify associated environmental sample results accordingly.

The EPA Functional Guidelines for review of organic data state that no data qualification action is taken on the basis of MS/MSD results alone. The data reviewer exercises professional judgement in considering these results in conjunction with the results of laboratory control samples (LCSs) and other QC criteria in applying qualifications to the data.

The inorganic data review in EPA Functional Guidelines allows professional judgement to be applied in evaluating the results of matrix spikes. Generally, if spike recovery is greater than the upper acceptance limits, nondetections are not qualified. If spike recovery is greater than the upper acceptance limit or less than the lower acceptance limit, positive results are qualified as estimated (J) and nondetections are qualified as estimated (UJ). If spike recovery is less than 30 percent (grossly low), positive results are not qualified and nondetections are qualified as unusable (R).

\section{A.4.7.2 Laboratory Quality Control Samples}

Analysis of method QC blanks and surrogate spikes for organic analyses, method blanks, preparation blanks, initial and continuing calibration blanks for total metals, and LCS were performed for each SDG by Paragon Analytics, Inc. The results of these analyses were used to qualify associated environmental sample results according to EPA Functional Guidelines (EPA, 1994b and 1994c).

The EPA Functional Guidelines (EPA, 1994b and 1994c) state that no qualification action is taken if a compound is found in an associated blank, but not in the sample or if a compound is found in the sample, but not in an associated blank. The action taken when a compound is detected in both the 
sample and the associated blank varies depending upon the analyte involved and is described in the “The 5X/10X Rule."

For most VOCs, SVOCs, herbicides, and pesticides, if an analyte is detected in the sample and was also detected in an associated blank the result is qualified as undetected (U) if the sample concentration is less than five times $(5 \mathrm{X})$ the blank concentration.

For the common laboratory contaminants (e.g., methylene chloride, acetone, 2-butanone [methylethyl ketone or MEK], and phthalate esters [especially bis(2-ethylhexyl)phthalate]), the factor is raised to ten times $(10 \mathrm{X})$ the blank concentration. The sample result is elevated to the quantitation limit if it is less than the quantitation limit or remains unaltered if the sample result is greater than or equal to the quantitation limit.

For inorganics (i.e., metals), sample results greater than the instrument detection limit, but less than five times $(5 \mathrm{X})$ the amount found in an associated blank, are qualified as undetected (U). There are no metallic common laboratory contaminants, so there is no "10X Rule" for metals, and the sample result is never altered. When applying the $5 \mathrm{X}$ criteria to soil sample data or calibration blank data, the raw data results are used to evaluate and qualify the reported results on the Certificate of Analysis.

Surrogate spikes, or system monitoring compounds, are added to the environmental samples analyzed by chromatographic techniques for VOCs, SVOCs, pesticides, PCBs, gasoline, and diesel. Surrogate compounds are analytes that are not expected to be present in associated environmental samples, but behave the same as similar target compounds chromatographically. Known amounts of each surrogate are added prior to sample preparation and are carried throughout the preparation/analysis procedure. The percent recoveries of these surrogate compounds give some measure of the anticipated recoveries of the target compounds whose chromatographic behavior they mimic.

If any surrogate percent recoveries are out of the acceptable range (which differs for each surrogate in each method), laboratory protocol calls for the sample to be reprepared and/or reanalyzed. When the surrogate recoveries are acceptable on the second run, only the second analysis results are reported. When both analyses yield the same unacceptable range, the results of both analyses are reported. 
The evaluation of surrogate spike percent recovery results is not straightforward. The functional guidelines suggest several optional approaches, but require the data reviewer to exercise professional judgement in reviewing surrogate data and qualifying associated data as estimated ( $\mathrm{J}$ or $\mathrm{UJ}$, for detections or nondetections, respectively) or unusable (R). Documentation of data qualifications resulting from the application of these guidelines is retained in the project files as both hard copy and electronic media.

One laboratory duplicate analysis for metals was performed for each SDG that reported total metals. The duplicate results are compared to the results of the original sample to give a measure of analytical laboratory precision. If the results from a duplicate analysis for a particular analyte fall outside the control limits, the EPA Functional Guidelines for Inorganic Data Review (EPA, 1994c) call for all results for that analyte in all associated samples of the same matrix to be qualified as estimated (J). Documentation of data qualifications resulting from the application of these guidelines is retained in the project files as both hard copy and electronic media.

Laboratory control samples, also known as blank spikes, consist of known quantities of target compounds added to purified sand or deionized, distilled water and analyzed along with the environmental samples in the sample delivery group. The percent recoveries of the compounds in the LCS give a measure of laboratory accuracy. The functional guidelines call for the data reviewer to use professional judgement to qualify associated data according to established criteria.

Documentation of data qualifications resulting from the application of these guidelines is retained in project files as both hard copy and electronic media.

\section{A.4.8 Field Nonconformances}

A procedural deficiency was identified during Tier I review. Three samples arrived at the Bechtel Nevada Analytical Services Laboratory without custody tape on the sample containers. Because the samples were hand delivered and remained in the custody of the sample collector until relinquished to the laboratory, there was no breach of custody. The resultant data was not impacted. 


\section{A.4.9 Laboratory Nonconformances}

Laboratory nonconformances are generally due to inconsistencies in analytical instrumentation operation, sample preparations, extractions, and fluctuations in internal standard and calibration results. Several laboratory nonconformances were documented for this project. These nonconformances have been accounted for in the data qualification process. All nondetect acrolein results were rejected due to the compounds response in the initial calibration. The laboratory is not required to generate a nonconformance for this type of deficiency as long as the laboratory met all the required QC criteria for the initial calibration analysis. Documentation of these results is retained in project files. 


\section{A.5.0 Summary}

Analysis of the data generated from corrective action investigation activities conducted at the Area 25

Vehicle Washdown sites indicates the following:

- All total VOCs, total SVOCs, PCBs, and pesticides results were below the PALs outlined in the CAIP (DOE/NV, 1999) at all CASs.

- Total petroleum hydrocarbon concentrations exceeded the NDEP action level of $100 \mathrm{mg} / \mathrm{kg}$ for diesel around the perimeter of the concrete decontamination pad at F and J Roads Pad. The TPH action level was not exceeded at the other two CASs.

- Reported levels for all total RCRA metal samples (arsenic, barium, cadmium, chromium, lead, mercury, selenium, and silver) were below the PALs established in the CAIP (DOE/NV, 1999) except for arsenic. Arsenic was detected above the PAL of $3.0 \mathrm{mg} / \mathrm{kg}$ in most of the samples analyzed. The arsenic concentrations for the samples analyzed ranged from 1.9 to $10.2 \mathrm{mg} / \mathrm{kg}$. Although these concentrations exceed the PAL for arsenic, these concentrations are not unusual for this portion of the state of Nevada; therefore, these concentrations do not imply contamination and arsenic is not a COC.

- Radiological results for the Propellant Pad and the RADSAFE Pad are considered not to be statistically different from their respective established background levels and; therefore, are below PALs.

- Radiological results from the F and J Roads Pad indicated that two samples had concentrations above established background levels and; therefore, are above PALs. Sample VWDFJ011 had a strontium-90 concentration of $6.9 \pm 1.3 \mathrm{pCi} / \mathrm{g}$. Sample VWDFJ013 had cesium-137 and strontium-90 concentrations of $14.7 \pm 1.6 \mathrm{pCi} / \mathrm{g}$ and $12.5 \pm 2.3 \mathrm{pCi} / \mathrm{g}$, respectively. All other results, including the isotopic uranium and plutonium results for sample VWDFJ013, are considered not to be statistically different from their respective established background levels and; therefore, are below PALs. 


\section{A.6.0 References}

AEC, see U.S. Atomic Energy Commission.

Atlan-Tech. 1992. Environmental Monitoring Report for the Proposed Ward Valley California Low Level Radioactive Waste (LLRW) Facility. Rosewell, GA: Atlan-Tech, Inc.

Bechtel Nevada Analytical Services Laboratory. 1999. Bechtel Nevada Analytical Services Laboratory Procedures Manual. Las Vegas, NV.

BN ASL, see Bechtel Nevada Analytical Services Laboratory.

DOE/NV, see U.S. Department of Energy, Nevada Operations Office.

EC, see Environment Canada.

EPA, see U.S. Environmental Protection Agency.

Environment Canada, Commercial Chemicals Evaluation Branch. 1999. COMMERCIAL CHEMICALS Website, "Acrolein." Hull, Quebec: available online at http://24.112.94.181/cceb1/eng/substances/acrolein.htm as accessed on 7/16/99.

FFACO, see Federal Facility Agreement and Consent Order.

Federal Facility Agreement and Consent Order. 1996 (as amended). Agreed to by the State of Nevada, the U.S. Department of Energy, and the U.S. Department of Defense.

IT, see IT Corporation.

IT Corporation. 1998a. Field Activity Daily Log for site visit B. Bordelois and C. Rodriguez to CAU 240, CAS 25-07-01, CAS 25-07-02, and CAS 25-07-03, 28 September. Las Vegas, NV.

IT Corporation. 1998b. Site-Specific Health and Safety Plan, Area 25 Vehicle Washdown, Nevada Test Site. Las Vegas, NV.

McArthur, R.D., and F.L. Miller, Jr. 1989. Off-Site Radiation Exposure Review Project, Phase II Soil Program, DOE/NV/10384--23. Las Vegas, NV: Desert Research Institute.

Moore, J. 1999. Memorandum to M. Todd (SAIC), entitled "Background Concentrations for NTS and TTR Soil Samples,” 3 February. Las Vegas, NV: IT Corporation.

NAC, see Nevada Administrative Code.

NBMG, see Nevada Bureau of Mines and Geology. 
Nevada Administrative Code. 1997. NAC 445A.227, "Contamination of soil: Order by director of corrective action; factors to be considered in determining whether corrective action is required." Carson City, NV.

Nevada Bureau of Mines and Geology. 1998. Mineral and Energy Resource Assessment of the Nellis Air Force Range, Open-File Report 98-1. Reno, NV.

PAI, see Paragon Analytics, Incorporated.

Paragon Analytics, Incorporated. 1996 and 1999. Paragon Analytics, Incorporated Standard Operation Procedures Manual.

Sorom, E. 1998. Record of telecon with B. Bordelois (SAIC) and E. Sorom (retired from REECO) regarding $\mathrm{F}$ and $\mathrm{J}$ Roads Pad and RADSAFE Pad, the nature of their activities, and the trailer location, 28 April and 12 June. Las Vegas, NV.

SNPO, see Space Nuclear Propulsion Office.

Space Nuclear Propulsion Office. 1965. Atomic Energy Commission (AEC) - National Aeronautics Administration (NASA). Drawings NRDS-SF-P18/C-1 and NRDS-SF-P18/C-2. LH2 Sampling Facility Civil \& Piping Details. Jackass Flats, NV.

Space Nuclear Propulsion Office. 1970. NRDS Master Plan 1969-1970, Nuclear Rocket Development Station, Jackass Flats, Nevada. Las Vegas, NV.

U.S. Atomic Energy Commission. 1961. Structure 3152 Rad Safe Bldg. Miscellaneous Layout and Details, Drawing RE-3152-C2. Las Vegas, NV.

U.S. Department of Energy, Nevada Operations Office. 1988. CERCLA Preliminary Assessment of DOE's Nevada Operations Office, Nuclear Weapons Testing Area, Vol. I. Las Vegas, NV.

U.S. Department of Energy, Nevada Operations Office. 1996. Industrial Sites Quality Assurance Project Plan, Nevada Test Site, Nevada, Rev. 1, DOE/NV--372. Las Vegas, NV.

U.S. Department of Energy, Nevada Operations Office. 1999. Corrective Action Investigation Plan for CAU 240: Area 25 Vehicle Washdown, Nevada Test Site, Nye County, Nevada, DOE/NV--532. Las Vegas, NV: IT Corporation.

U.S. Environmental Protection Agency. 1987. Data Quality Objectives for Remedial Response Activities, EPA/540/G-87-003. Washington, DC.

U.S. Environmental Protection Agency. 1989. AQUIRE Database, ERL-Duluth, U.S. EPA, Phytotox and Terretox databases. Available at http://mail.odsnet.com/TRIFacts/27.html. 
U.S. Environmental Protection Agency. 1994a. Guidance for the Data Quality Objectives Process, EPA QA/G-4. Washington, DC.

U.S. Environmental Protection Agency. 1994b. Contract Laboratory Program National Functional Guidelines for Organic Data Review, EPA 540/R-94/012. Washington, DC.

U.S. Environmental Protection Agency. 1994c. Contract Laboratory Program National Functional Guidelines for Inorganic Data Review, EPA 540/R-94/013. Washington, DC.

U.S. Environmental Protection Agency. 1996. Test Methods for Evaluating Solid Waste, Physical/Chemical Methods, SW-846, CD ROM which contains updates for 1986, 1992, 1994 and 1996. Washington, DC.

U.S. Environmental Protection Agency. 1998. Memo from S.J. Smucker to PRG Table Mailing List regarding Region 9 Preliminary Remediation Goals (PRGs), 1 August. San Francisco, CA.

USGS, see U.S. Geological Survey.

U.S. Geological Survey. 1993. Selected Ground-Water Data for Yucca Mountain Region, Southern Nevada and Eastern California, Calendar Year 1993, Open-File Report 95-158. 
Appendix B

Cost Estimates 


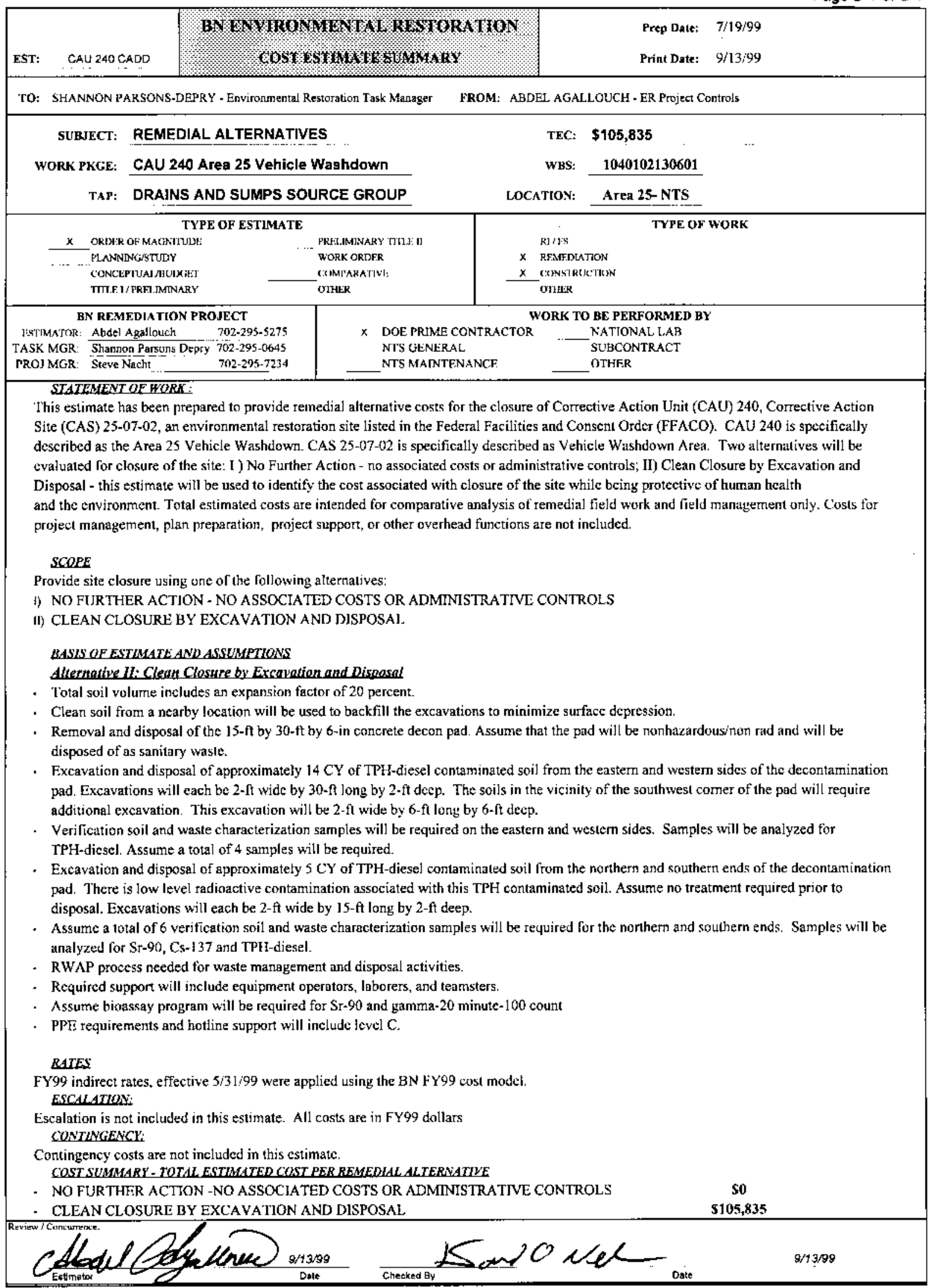




\section{Appendix C}

\section{Response to NDEP Comments}




\section{NEVADA ENVIRONMENTAL RESTORATION PROJECT}

DOCUMENT REVIEW SHEET

(Page 1 of 3 )

\begin{tabular}{|c|c|c|c|c|c|}
\hline \multicolumn{2}{|c|}{ 1. Document Title/Number: } & $\begin{array}{l}\text { Draft Corrective Action Decision Document for Corrective Actic } \\
25 \text { Washdown, Nevada Test Site, Nevada }\end{array}$ & Unit 240: Area & \multicolumn{2}{|l|}{ 2. Document Date: July 1998} \\
\hline \multicolumn{4}{|c|}{ 3. Revision Number: 0} & \multicolumn{2}{|c|}{ 4. Originator/Organization: IT Corporation } \\
\hline \multicolumn{4}{|c|}{ 5. Responsible DOE/NV ERP Project Mgr.: Janet Appenzeller-Wing } & \multicolumn{2}{|c|}{ 6. Date Comments Due: August 26, 1999} \\
\hline \multicolumn{6}{|c|}{ 7. Review Criteria: Full } \\
\hline \multicolumn{3}{|c|}{ 8. Reviewer/Organization/Phone No.: John A. Wong/NDEP/702-486-2866 } & & \multicolumn{2}{|l|}{ 9. Reviewer's Signature: } \\
\hline $\begin{array}{l}10 . \\
\text { Comment } \\
\text { Number/ } \\
\text { Location }\end{array}$ & 11. Type* & 12. Comment & \multicolumn{2}{|c|}{ 13. Comment Response } & $\begin{array}{c}14 . \\
\text { Accept }\end{array}$ \\
\hline $\begin{array}{c}1 . \\
\text { Page } 7 \\
\text { Section } 2.2 \\
\text { 3rd bullet }\end{array}$ & & $\begin{array}{l}\text { Add silver to the list of RCRA metals. Also DOE needs to state what } \\
\text { levels of arsenic were observed in background samples to } \\
\text { substantiate the claim that typical concentrations of arsenic in this } \\
\text { part of Nevada are higher than the PAL of } 3.0 \mathrm{ppm} \text {. }\end{array}$ & \multicolumn{2}{|c|}{$\begin{array}{l}\text { Silver has been added to the list of RCRA Metals. Section } \\
\text { A.3. } 4 \text { provides a mean concentration of arsenic observed in } \\
\text { background samples. }\end{array}$} & Yes \\
\hline $\begin{array}{c}2 . \\
\text { Page 17, } \\
\text { Section 3.3.2, } \\
\text { Last } \\
\text { Paragraph }\end{array}$ & & $\begin{array}{l}\text { "Activities will include...and } 5 \mathrm{yd}^{3} \text { of TPH with associated } \\
\text { radionuclide contamination." I believe that "soil" should be inserted } \\
\text { in place of "TPH" in this sentence. Also, soil in the SW corner will be } \\
\text { excavated to } 6 \mathrm{ft} \text { bgs. Is sample VWDFJ023 located in the SW } \\
\text { corner? According to Table A.3-4, sample location GP9 } \\
\text { (VWDFJ023) was found to contain } 380 \mathrm{ppm} \text { TPH. Based on the } \\
\text { results presented in this table, most of the contamination is present } \\
\text { at a depth within } 1 \mathrm{ft} \text { bgs. How was it determined that soil in the SW } \\
\text { corner will be excavated to a depth of } 6 \mathrm{ft} \text { bgs and soil at the } \\
\text { perimeter excavated to a depth of } 2 \mathrm{ft} \text { bgs? Are the plans for } \\
\text { excavation consistent with the sample results in Table A.3-4, page } \\
\text { A-24. Please address, verify, and/or confirm. }\end{array}$ & \multicolumn{2}{|c|}{$\begin{array}{l}\text { The sentence has heen modified as follows: "Activities will } \\
\text { include....and } 5 \mathrm{yd}^{3} \text { of TPH and radionuclide contaminated } \\
\text { soil." Sample VWDFJ023 was collected from near the } \\
\text { southwest corner at a depth of } 3-5 \mathrm{ft} \text { bgs. Most of the } \\
\text { contamination is within } 1 \mathrm{ft} \text { bgs. The contamination at } \\
\text { location GP9 extends to the } 3-5 \mathrm{ft} \text { bgs interval. The depths } \\
\text { of excavation necessary to remove contaminated soil that } \\
\text { exceeds action levels are estimated in the CADD. For } \\
\text { example, sample results indicate contamination at several } \\
\text { locations at a depth of } 0-1 \mathrm{ft} \text { bgs, but not at } 3-5 \mathrm{ft} \text { bgs. The } \\
\text { assumption was made that contamination extends beyond } 1 \\
\mathrm{ft} \text { bgs at these locations to } 2 \mathrm{ft} \text { bgs. The estimates for } \\
\text { excavation are consistent with the sample results in } \\
\text { Table A.3-4. }\end{array}$} & Yes \\
\hline
\end{tabular}


NEVADA ENVIRONMENTAL RESTORATION PROJECT

DOCUMENT REVIEW SHEET

(Page 2 of 3 )

\begin{tabular}{|c|c|c|c|c|}
\hline $\begin{array}{l}10 . \\
\text { Comment } \\
\text { Number/ } \\
\text { Location }\end{array}$ & 11. Type* & 12. Comment & 13. Comment Response & $\begin{array}{c}14 . \\
\text { Accept }\end{array}$ \\
\hline $\begin{array}{c}\text { 3. } \\
\text { Page A-3, } \\
\text { Section A.2.0, } \\
\text { 1st } \\
\text { Paragraph, } \\
\text { 2nd Sentence }\end{array}$ & & Capitalize "field" screening. & $\begin{array}{l}\text { This sentence has been deleted. The information deleted } \\
\text { here is in Section A.2.2.5. }\end{array}$ & Yes \\
\hline $\begin{array}{c}4 . \\
\text { Page A-25, } \\
\text { Table A.3-5 }\end{array}$ & & $\begin{array}{l}\text { Why have results for cadmium and silver, two of the eight RCRA } \\
\text { metals, been excluded from this table? Please add these results. }\end{array}$ & $\begin{array}{l}\text { The results for cadmium and silver have been excluded from } \\
\text { this table because the concentrations of these constituents } \\
\text { were not detected above the approved minimum reporting } \\
\text { limits. }\end{array}$ & No \\
\hline $\begin{array}{c}5 . \\
\text { Page A-35, } \\
\text { Section A.4.6, } \\
\text { 1st } \\
\text { Paragraph, } \\
\text { 3rd Sentence }\end{array}$ & & $\begin{array}{l}\text { "There were no data rejected..." This statement is not accurate if } \\
\text { indeed a portion of acrolein results were rejected as stated (see } \\
\text { Section A.4.4, among other locations in the document where it was } \\
\text { stated that some results for acrolein were rejected). }\end{array}$ & $\begin{array}{l}\text { The subject sentence has been replaced with the following: } \\
\text { "No data rejected during the data evaluation process were } \\
\text { used to draw the conclusions presented in the CADD." The } \\
\text { reader is also referred in Section A.4.4 to Section A.3.1 for } \\
\text { more information regarding rejected data for acrolein. }\end{array}$ & Yes \\
\hline
\end{tabular}


NEVADA ENVIRONMENTAL RESTORATION PROJECT

DOCUMENT REVIEW SHEET

(Page 3 of 3 )

\begin{tabular}{|c|c|c|c|c|}
\hline $\begin{array}{c}10 . \\
\text { Comment } \\
\text { Number/ } \\
\text { Location }\end{array}$ & 11. Type* & 12. Comment & 13. Comment Response & $\begin{array}{c}14 . \\
\text { Accept }\end{array}$ \\
\hline $\begin{array}{c}6 . \\
\text { Page A-38, } \\
\text { Section } \\
\text { A.4.7-A.4.7.2 }\end{array}$ & & $\begin{array}{l}\text { Why were QC sample results compared with EPA Functional } \\
\text { Guidelines. EPA Functional Guidelines and criteria apply to CLP } \\
\text { activities. It seems as though the QC results for this project should } \\
\text { be compared to project-specific DQOs, which should have been } \\
\text { established in the Final CAIP or the Industrial Sites QAPP. }\end{array}$ & $\begin{array}{l}\text { The QC sample results were initially compared to the } \\
\text { project-specific DQOs, which are stated in the CAIP's } \\
\text { "Laboratory Analytical Requirements," Table A.3-4. This } \\
\text { table was used to create the Analytical Services Request } \\
\text { Form before sampling activities commenced. The } \\
\text { laboratory followed the QC criteria stated in the Analytical } \\
\text { Services Request Form. When the analytical results arrived } \\
\text { from the laboratory, Tier II Data Validation was performed. } \\
\text { Tier II Data Validation followed the guidelines set forth in the } \\
\text { U.S. EPA's Contract Laboratory Program National } \\
\text { Functional Guidelines for Inorganic and Organic Data } \\
\text { Review, published in February } 1994 \text {. The data review } \\
\text { process provides information on analytical limitations and } \\
\text { data usability based on specific QC criteria stated in the } \\
\text { "Laboratory Analytical Requirements" table. The EPA } \\
\text { Functional Guidelines provide guidance in the data } \\
\text { qualification of the analytical results using an overview of all } \\
\text { QC results. The data validation process provided the } \\
\text { technical review of analytical data based on the CAIP's } \\
\text { "Laboratory Analytical Requirements" table criteria. The } \\
\text { EPA Functional Guidelines document applies to non-CLP } \\
\text { activities as long as the QC criteria being followed are the } \\
\text { criteria stated by the project or by the method. Third party } \\
\text { contractors performing Tier III Data Validation also follow the } \\
\text { EPA Functional Guidelines. }\end{array}$ & Partial \\
\hline $\begin{array}{c}7 . \\
\text { Page A-43, } \\
\text { 3rd bullet }\end{array}$ & & Add silver to the list of RCRA metals. & Silver has been added to the list of RCRA Metals. & Yes \\
\hline
\end{tabular}

a Comment Types: $M=$ Mandatory, $S=$ Suggested

Return Document Review Sheets to DOE/NV Environmental Restoration Division, Attn: QAC, M/S 505. 


\section{Distribution}

*Provide copy in distribution of Revision 0 and subsequent revisions if applicable. Copies of only the NDEP-approved document will be distributed to others.

Paul J. Liebendorfer

State of Nevada

Bureau of Federal Facilities

Division of Environmental Protection

333 W. Nye Lane, Room 138

Carson City, NV 89706-0851

Mike McKinnon

State of Nevada

Bureau of Federal Facilities

Division of Environmental Protection

555 E. Washington, Suite 4300

Las Vegas, NV 89101

Sabrina Lawrence

Environmental Restoration Division

DOE/Nevada Operations Office

P.O. Box 98518, M/S 505

Las Vegas, NV 89193-8518

Janet Appenzeller-Wing

Environmental Restoration Division

DOE/Nevada Operations Office

P.O. Box 98518, M/S 505

Las Vegas, NV 89193-8518

Sabine Curtis

Environmental Restoration Division

DOE/Nevada Operations Office

P.O. Box 98518, M/S 505

Las Vegas, NV 89193-8518

Wayne Johnson

Bechtel Nevada

P.O. Box 98521, M/S NTS306

Las Vegas, NV 89193-8521
2 (Controlled)*

1 (Controlled)*

1 (Controlled)*

1 (Uncontrolled)*

1 (Uncontrolled)*

1 (Uncontrolled)* 
Shannon Parsons-DePry

Bechtel Nevada

P.O. Box 98521, M/S NTS306

Las Vegas, NV 89193-8521

Dustin Wilson

SAIC

P.O. Box 93838

Las Vegas, NV 89193

Beatriz Bordelois

SAIC

P.O. Box 93838

Las Vegas, NV 89193

IT Corporation Central Files

IT Corporation

P.O. Box 93838

Las Vegas, NV 89193

Technical Information Resource Center

DOE/Nevada Operations Office

IT Corporation

P.O. Box 93838

Las Vegas, NV 89193

U.S. Department of Energy

Office of Scientific and Technical Information

P.O. Box 62

Oak Ridge, TN 37831

Manager Southern Nevada FFACO

Public Reading Room

P.O. Box 98521, M/S NLV040

Las Vegas, NV 89193-8521
1 (Uncontrolled)*

1 (Uncontrolled)*

1 (Uncontrolled)*

1 (Uncontrolled)*

1 (Uncontrolled)

1 (Uncontrolled, electronic copy)

1 (Controlled)

1 (Uncontrolled) 
Manager Northern Nevada FFACO

Public Reading Room

c/o Rosa Silver

IT Corporation

P.O. Box 93838

Las Vegas, NV 89193

FFACO Public Reading Rooms Coordinator

Rosa Silver

IT Corporation

P.O. Box 93838

Las Vegas, NV 89193
1 (Uncontrolled)

1 (Controlled) 